\title{
FINAL REPORT PHASE I
}

\author{
VOLUME II OF IV \\ BOOK 2 OF 4
}

ASSESSMENT OF UNDERGROUND COAL GASIFICATION IN BITUMINOUS COALS

- POTENTIAL UCG PRODUCTS AND MARKETS

prepared for the

U.S. DEPARTMENT OF ENERGY MORGANTOWN ENERGY TECHNOLOGY CENTER UNDER CONTRACT NO. DE-AC05-80MC 14584

\section{PROCESS DIVISION \\ OF \\ WILLIAMS BROTHERS ENGINEERING COMPANY

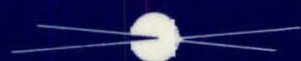 \\ A Resource Sciences Company}




\section{DISCLAIMER}

This report was prepared as an account of work sponsored by an agency of the United States Government. Neither the United States Government nor any agency Thereof, nor any of their employees, makes any warranty, express or implied, or assumes any legal liability or responsibility for the accuracy, completeness, or usefulness of any information, apparatus, product, or process disclosed, or represents that its use would not infringe privately owned rights. Reference herein to any specific commercial product, process, or service by trade name, trademark, manufacturer, or otherwise does not necessarily constitute or imply its endorsement, recommendation, or favoring by the United States Government or any agency thereof. The views and opinions of authors expressed herein do not necessarily state or reflect those of the United States Government or any agency thereof. 


\section{DISCLAIMER}

Portions of this document may be illegible in electronic image products. Images are produced from the best available original document. 


\section{The following pages are an exact representation of what is in the original document folder.}




$$
D O E / M C / 14584--1193-V 0 / .2-B K .2
$$

PROCESS

DIVISION

c.

MULAMS BROTHERS

ENGANERENG COMPANY

A Ascource Sebroes Compons

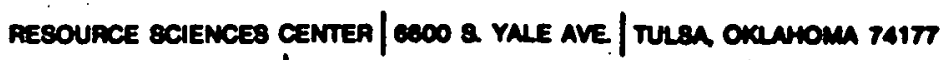

PHONE (010) 4006000/ TELEX 4007400 WBectrL

$$
\mathrm{DOE} / \mathrm{MC} / 14584--1193 \mathrm{Vol} \cdot 2-\mathrm{Bk} \cdot 2
$$

January 31, 1982 DE82 014583

U.S. Department of Energy

Morgantown Energy Technology Center

P.O. Box 880

Collins Ferry Road

Morgantown, West Virginia 26505

Attention: Mr. Joe Martin, Techntcal officer (13)

Re: Final Report Phase I

Assessment of UCG in Bituminous coals

Volume II of IV

Book 2 of 4

Contract No. DE-AC05-80MC14584

WBEC-4389-T-44

Gentlemen :

Williams Brothers Engineering Company is pleased to submit fifteen (15) copies and one (1) reproducible master of the Final Report Phase I - Assessment of UCG in Bituminous Coals, Bituminous Coal Resource Evaluation.

sincerely,

Process Division

WILLIAMS BROTHERS ENGINEERING COMPANY

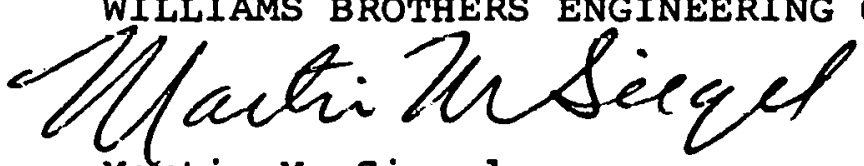

Martin M. Siegel

Manager of Alternate Fuels Processing

Attachment

MMS : skn/4389/

cc: Steven Grumbach (2)

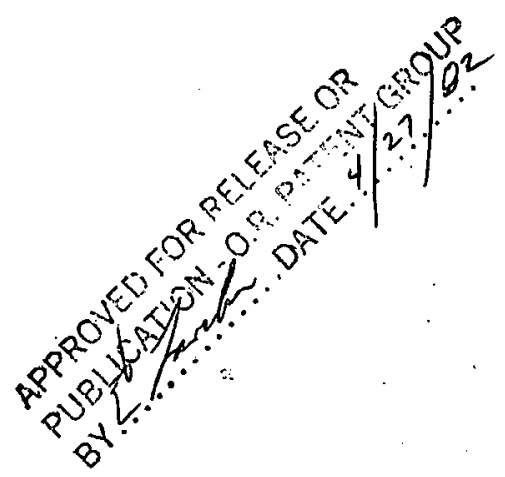




\title{
FINAL REPORT
PHASE I
}

\author{
VOLUME II OF IV \\ BOOK 2 OF 4
}

\begin{abstract}
ASSESSMENT OF UNDERGROUND COAL GASIFICATION IN BITUMINOUS COALS
\end{abstract}

- POTENTIAL UCG PRODUCTS AND MARKETS

\author{
prepared for the \\ U.S. DEPARTMENT OF ENERGY \\ MORGANTOWN ENERGY TECHNOLOGY CENTER \\ UNDER CONTRACT NO. DE-AC05-80MC 14584
}

PROCESS DIVISION

WILLIAMS BROTHERS ENGINEERING COMPANY

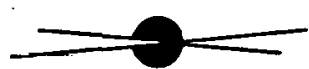

RESOURCE SCIENCES CENTER • TULSA, OKLAHOMA 74177 
This report was prepared as an account of work sponsored by the United States Government. Neither the United States nor the United States Department of Energy, nor any of their employees, makes any warranty, express or implied, or assumes any legal liability or responsibility for the accuracy, completeness, or usefulness of any information, apparatus, product, or process disclosed, or represents that its use would not infringe privately owned rights. Reference herein to any specific commerical product, process, or service by trade name, mark, manufacturer, or otherwise, does not necessarily constitute or imply its endorsement, recommendation or favoring by the United, States Government or any agency thereof. The views and opinions of authors expressed herein do not necessarily state or reflect those of .the United states Government of any agency thereof.

This technical report is being transmitted in advance of DOE review and no further dissemination or publication shall be made of the report without prior approval of the DOE Project/Program Manager. 


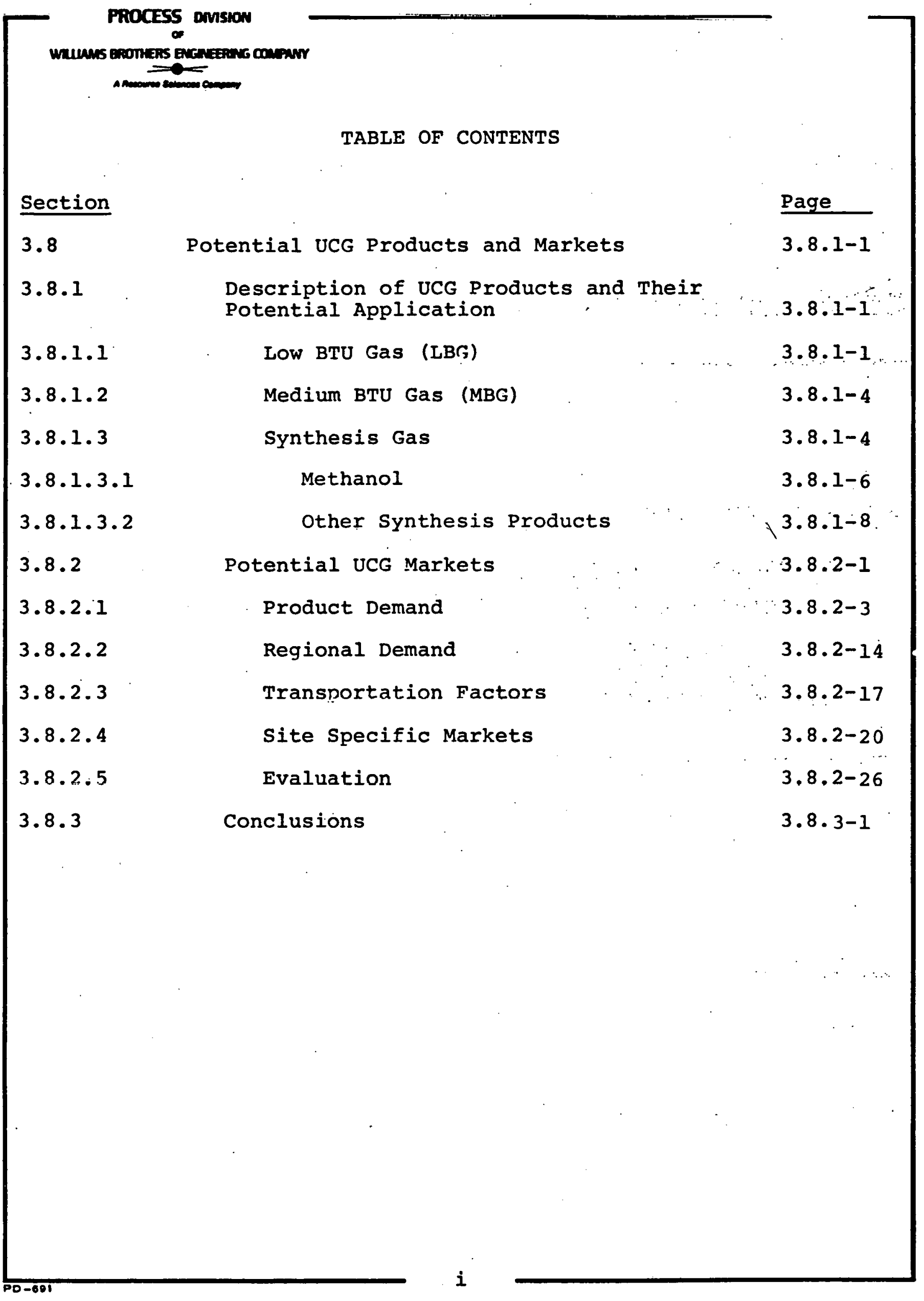




\subsection{POTENTIAL UCG PRODUCTS AND MARKETS}

This section identifies the potential products and markets for UCG facilities located near certain target areas in the Eastern U.S. where bituminous resources amenable to UCG have been located. The identification of potential markets and uses for the gas near designated target areas will help to substantiate suitability of these sites for development.

In subsection $3.8-1$, the products are discussed, then in subsection 3.8-2 the markets are evaluated.

\subsubsection{Description of UCG Products and Their Potential Application}

Underground Coal Gasification (UCG) of thin bituminous coals will produce either low-BTU gas $(80-125$ BTU/SCF $)$ or medium-BTU gas (160 - 250 BTU/SCF) depending on which oxygen source, air or pure oxygen, is used for combustion.. The low Btu product gas can be used as a fuel directly once sulfur and other contaminants are removed. The medium BTU gas can also be used as a fuel or it can be used as a synthesis feed gas for higher value products. Figure 3.8-1 illustrates the two different product schemes.

\subsubsection{Low BTU Fuel (LBG)}

Low BTU gas is generated by UCG when air is injected downhole as the feed gas. The produced gases can be burned after cleaning without further upgrading. As indicated in Table 3.8-1, the LBG from UCG in thin bituminous coal beds is similar to product gas from air blown surface gasifiers although the heating value of the in situ LBG is somewhat lower. The range of 80 to $125 \mathrm{BTU} / \mathrm{SCF}$ is expected to present no significant combustion problems.

A recent study was sponsored by the U.S. DOE [1], on combustion of low BTU gases $(116-287 \mathrm{BTU} / \mathrm{SCF})$. The report indicates that fuel gas produced by an air blown winkler gasifier (116 BTU/SCF) could produce a stable flame without assistance using a high-forward-momentum burner while nozzle mix and premix tunnel burners needed a continuous pilot light to maintain a stable flame. Fuel injection modifications were required to achieve stable flames on a forward-flow baffle, kiln and boiler burners. Based on this study, it does not appear that there is any major technological problem to the use of low BTU gas down to 116 BTU/SCF. Other operating experience suggests that even heating values down to the lower end of the low BTU gas from UCG scale at $80 \mathrm{BTU} / \mathrm{SCF}$ may be combustible. 


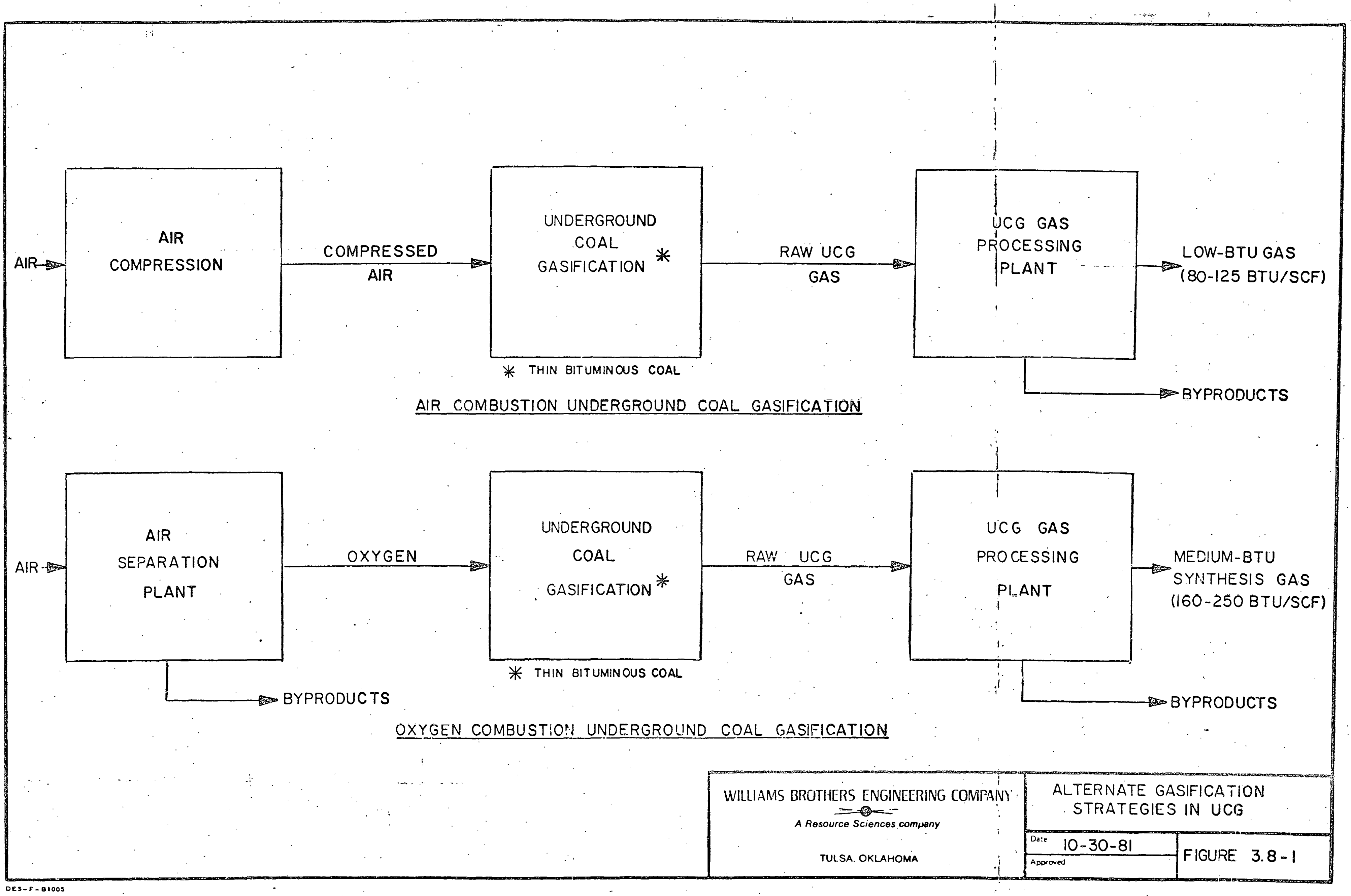




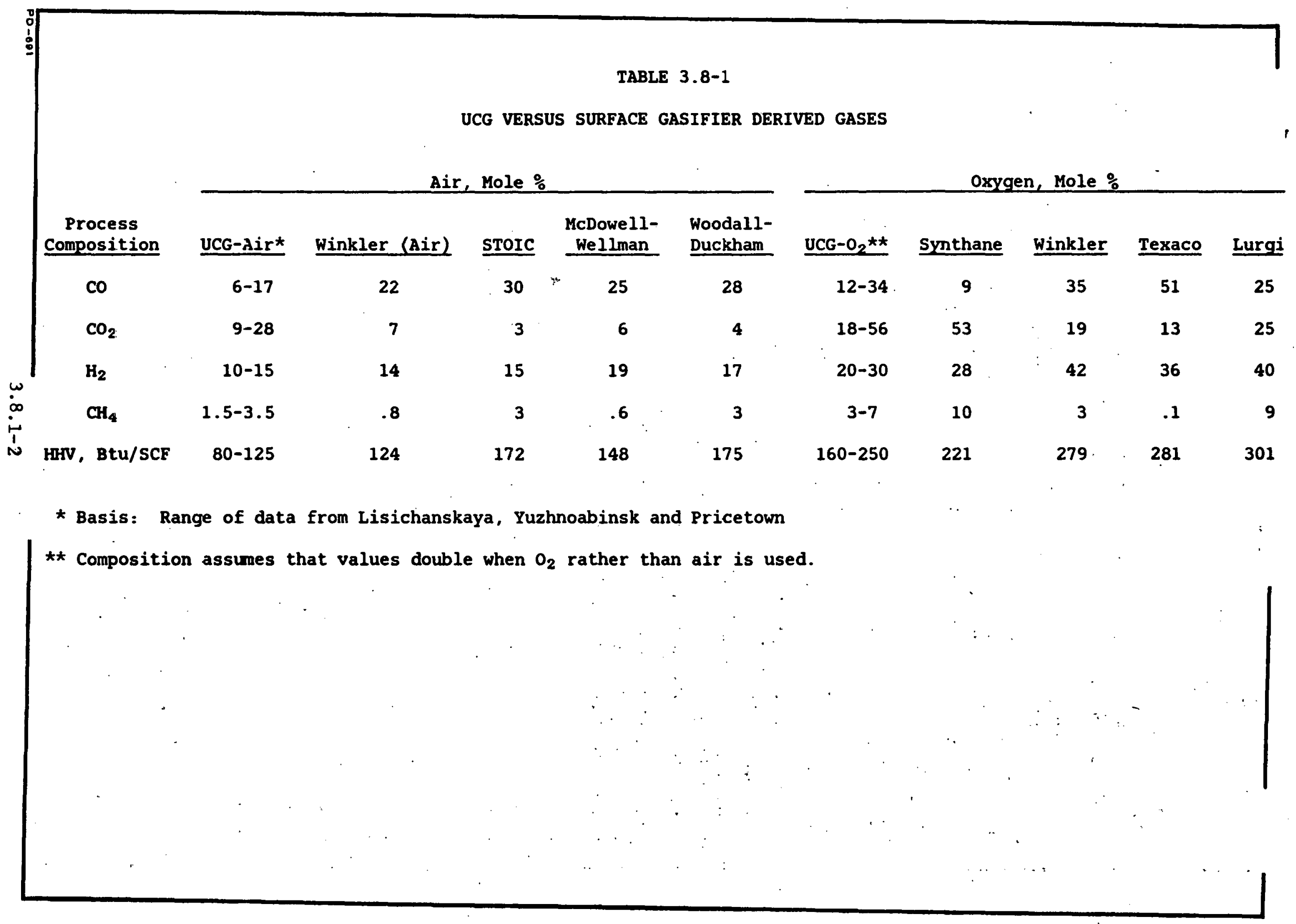


A report[2] on the use of low BTU oil shale by-product gas states: "Many Brown Boveri blast furnace installations operate on 80 to $90 \mathrm{BTU} / \mathrm{SCF}\left(712\right.$ to $\left.801 \mathrm{Kcal} / \mathrm{Nm}^{3}\right)$ fuel, with the lowest reported heating value being $76 \mathrm{BTU} / \mathrm{SCF}\left(676 \mathrm{Kcal} / \mathrm{Nm}^{3}\right)$."

In any event, if the heating value of the LBG dropped significantly below the point of efficient combustion, a small percentage of oxygen could be added to the feed gas to the gasifier to increase the heating value of the product. A small increase in oxygen content could be added to the existing air supply without major modifications to injection piping specifications.

Compression energy requirements for transmission of LBG may represent a substantial fraction of the total available energy in the gas. It is generally conceded that LBG is uneconomical to transport more than five to ten miles. Therefore, the product must be used within a short distance of the site where the gas is generated.

Potential uses for the LBG include power generation, industrial heating, and steam generation. The LBG fuel can be used to generate power in either existing power plants where it replaces coal, oil, or natural gas; or, in combined-cycle plants which could be located on-site. since it is unlikely that an existing power station would be located sufficiently close to a UCG site or would be willing to accept the necessary derating with LBG this option is reserved for MBG or SNG.

A combined-cycle power generator has definite advantages over a conventional coal fired power plant for the combustion of LBG. These advantages include modularization, higher efficiency, lower installed cost per kilowatt, less construction time, and less environmental impact. [3]

In a combined-cycle system, the LBG is mixed with compressed air and burned ahead of a gas turbine. Normally a common shaft off of the turbine is supplied to the air compressor and primary power generator. For higher value fuels, excess air must also be compressed and bypassed into the turbine to keep the temperature below that which could damage the blades. The exhaust gases from the turbine are then used to generate steam which drives a steam turbine connected to a secondary power generator, see Figure 3.8-2. Production of process steam in the economizer as well as secondary power will raise the overall efficiency of the system.

This type of equipment is conducive to skid-mounting and modularization. Once skid-mounted, the units can be moved to a UCG site as required by increased electrical demand or as the field develops to its optimum size. It is only necessary that a grid line be present to transport the energy. of course, the 


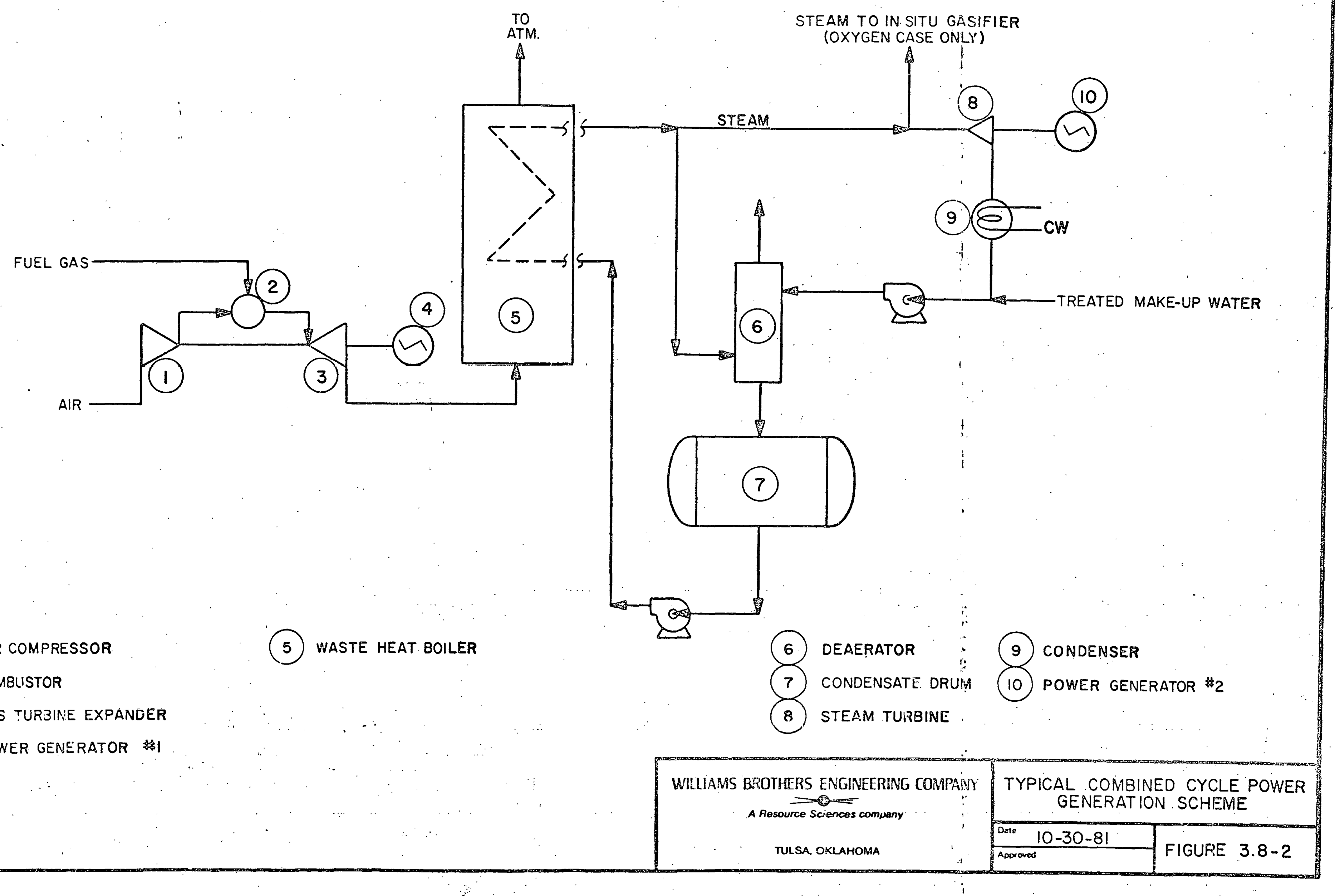


location of the site would depend on electric demand within the economic transmission radius of the power plant.

LBG can also be used in place of natural gas in most industries which currently use natural gas for heating; particularly, the steel, glass, cement, and brick industries. It may be that an industrial park could be established adjacent to a UCG facility to take advantage of a captive energy supply.

combining LBG with natural gas should not improve the economics of transporting it. However, if the pneumatic transport of fine coal over long distances ever becomes a reality, it will be worth investigating the use of LBG as the transport medium.

\subsubsection{Medium BTU Gas (MBG)}

Medium Btu gas is generated from UCG when oxygen and steam are used as the feed gas, see Figure 3.8-3. MBG can be used, in most cases, as a substitute for whatever fuel has been traditionally used with only a modest derating of the combustion system. However, MBG may be worth more as a synthesis gas for higher value products.

MBG from thin bituminous coal seams is lower in heating value than MBG from surface gasifiers, see Table 3.8-1. However, a heating value of $160-250$. BTU/SCF should be combustible under even adverse conditions. The higher end of the range should derate existing boilers by no more than 5-10\%. The derating comes about as a result of the larger volume of flue gas which must be handled and the longer flame length.

The higher heating value of MBG will permit economic transportation of the gas beyond the limits imposed on LBG. Its higher heating value, moreover, will make it acceptable by a larger share of industries. It may be possible to find a power plant which is close enough to the proposed site to receive the gas and back out part of its base fuel. The MBG will be low in sulfur and will burn without ash disposal requirements. There may be a scenario where this combination results in favorable economics.

\subsubsection{Synthesis Gas}

As oil and natural gas based feedstocks become more difficult to recover and thus more expensive, it is increasingly important to find suitable substitutes. A syn gas substitute can be at least part of the solution when the gases are derived from coal. Syn or synthesis gas is a mixture of hydrogen, carbon monoxide and generally carbon dioxide which is used in the preparation of higher value products. Because nitrogen is normally not tolerable, particularly at the levels experienced 


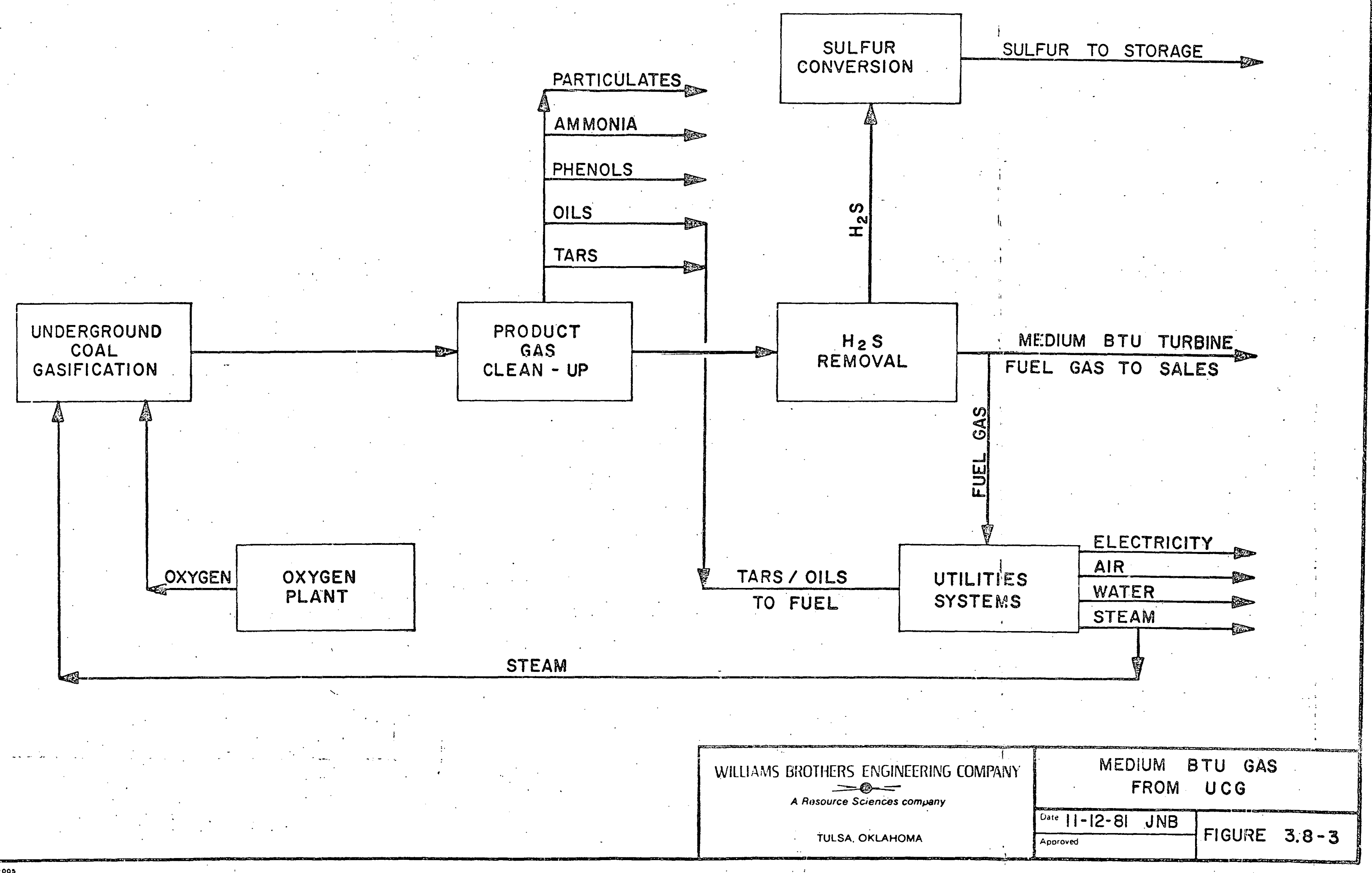


WILUAMS BROTHERS ENGENEERING COMPANY

A Remource Scionces compony

in LBG, the choice of suitable product gas is generally limited to MBG only.

As indicated in Table 3.8-1, product gas from UCG has a ratio of $\mathrm{H}_{2}$ to $\mathrm{CO}$ near 1.0 . This represents a relatively high ratio which is more favorable to syn gas utilization than product gas from most surface gasifier technologies. The lower the $\mathrm{H}_{2}$ to Co ratio, the more shift reaction is required in a subsequent process step to shift the $\mathrm{CO}$ to $\mathrm{H}_{2}$ by the reaction:

$$
\mathrm{CO}+\mathrm{H}_{2} \mathrm{O} \rightarrow \mathrm{H}_{2}+\mathrm{CO}_{2}
$$

The high hydrogen ratio in UCG product gas is primarily a result of the higher than required water influx characteristic of a UCG system and the catalytic nature of the coal ash. This effect, while beneficial from a syn gas viewpoint, is also a major reason for the lower than desirable heating value of the gas.

While the $\mathrm{H}_{2}$ to $\mathrm{CO}$ ratio is favorable, the methane content is not, unless SNG is to be produced. The high methane content $(3-7 \%)$, in both ammonia and methanol synthesis, must. be reformed to additional hydrogen and carbon oxides or separated. out and used as fuel. In either case, additional processing steps are required.

Before any coal derived gas can be shifted or utilized, it must first be treated to remove particulates, ammonia, phenols, tars and oils, and sulfur. The synthesis processes generally tolerate very little sulfur even to the extent of requiring a zinc oxide guard. Some modern shift processes, however, use a sulfur tolerant catalyst which permits the acid removal to take place totally on the downstream side.

Products which can be produced directly from coal derived syn gas include primarily: (See Figure 3.8-4)

$\begin{array}{ll}\circ & \text { Methanol } \\ \circ & \text { Ammonia } \\ \circ & \text { SNG } \\ \circ & \text { Synthetic Crude } \\ \circ & \text { Hydrogen } \\ \circ & \text { Carbon Monoxide } \\ \circ & \text { Carbon Dioxide }\end{array}$

Other processes are available to produce the following:

$\begin{array}{ll}\circ & \text { Glycols } \\ \circ & \text { Higher Alcohols } \\ \circ & \text { Acetic Anhydride }\end{array}$




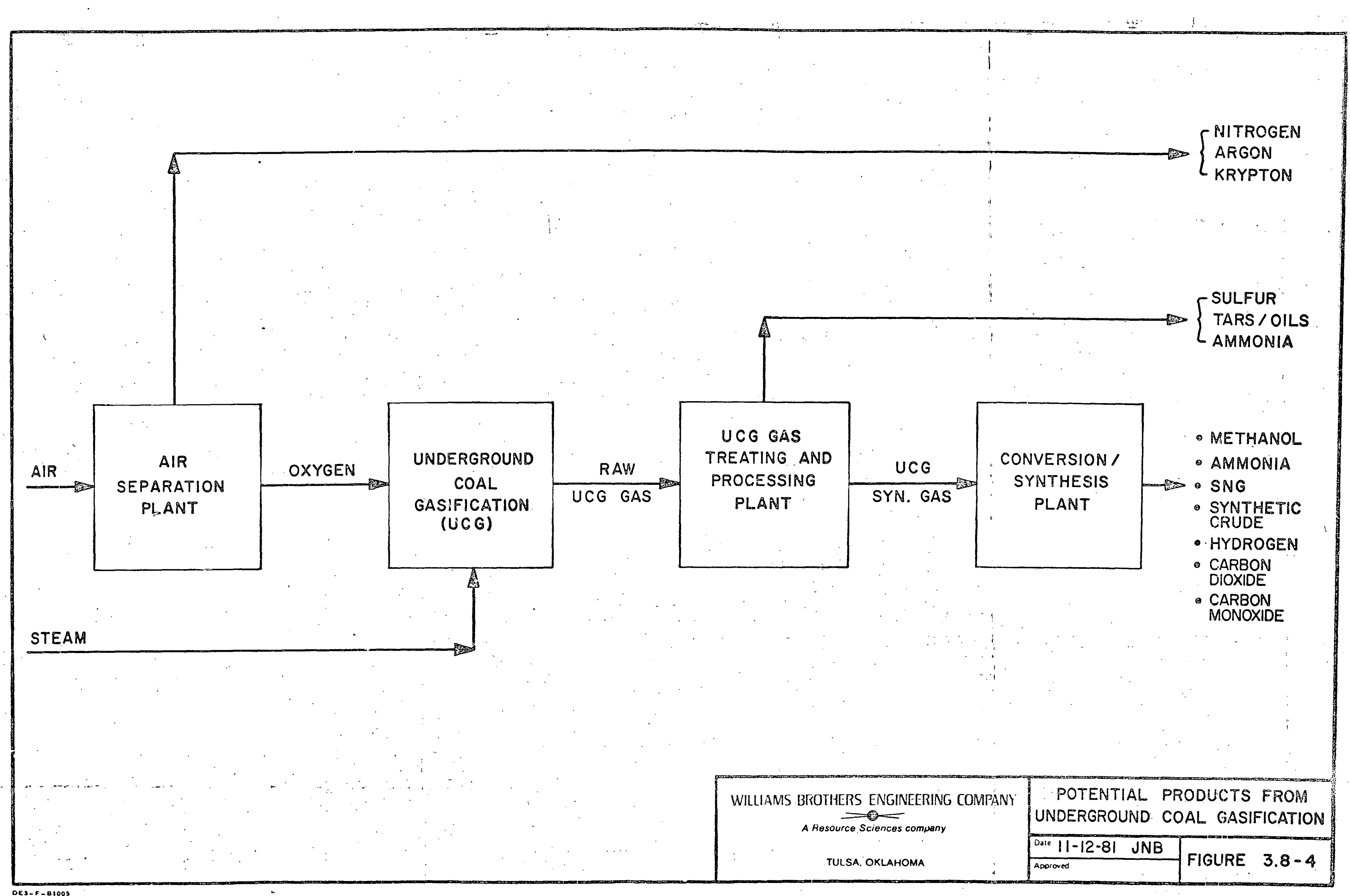


Further, many processes are available to convert primary products into secondary and tertiary products, such as:

$\begin{array}{ll}\text { 0 } & \text { Urea } \\ 0 & \text { MTBE } \\ 0 & \text { Olefins } \\ 0 & \text { Vinyl Acetate } \\ 0 & \text { Acetonitrile } \\ 0 & \text { Ethylene } \\ 0 & \text { Propylene } \\ 0 & \text { Butane } \\ \text { 0 } & \text { Formaldehyde } \\ \text { 0 } & \text { Ethanol } \\ \text { 0 } & \text { Terephthalic Acid } \\ \text { 0 } & \text { M-Gasoline } \\ \text { 0 } & \text { Ethylbenzene-Styrene } \\ \text { 0 } & \text { Methyl Methacrylate }\end{array}$

The synthesis products are not subject to the small economic transportation radius of the low to medium Btu gases. If SNG or methanol were produced, it is likely that existing natural gas or crude pipelines could be used. This could make the synthesis route attractive; however, the installations. visualized for eastern bituminous coals may not be large enough to justify the magnitude of expenditure required.

Of all the synthesis products, methanol may be the most versatile.

\subsection{Methanol}

Methanol may become the liquid fuel of the future. Because it is a liquid, it is not subject to the same distance limitations imposed on low to medium BTU gases. Existing oil pipelines could be used to transport methanol.

Methanol can be used as a fuel or chemical feedstock. As a fuel, it has been shown to be an excellent turbine fuel and with engine modifications a potential gasoline substitute for the internal combustion engine.

- Automobile Fuel

Methanol as a fuel substitute for gasoline has both advantages and disadvantages. The advantages include:

- lower NOX emission

- lower co emission

- lower unburnt hydrocarbon emission

- low residue formation

- very high octane $110 / 92 \mathrm{R} / \mathrm{M}$

- high density vapor 
WILLAMS BPOTHERS ENGINEERING COMPANY

The high octane permits a compression ratio of 12 to 14 versus the average compression ratio of 9 in present engines. The increased compression ratio should result in better thermal efficiency. Thermal efficiencies should be comparable to those experienced in diesel engines.

Theoretical temperature drop at stoiciometric air ratio and abiabatic evaporation is $20^{\circ} \mathrm{C}$ for gasoline and $122^{\circ} \mathrm{C}$ for methanol. While the gaseous mixture is not possible without auxilliary heating systems, a high mixture density caused by the temperature drop can result in better cylinder filling and resultant higher engine power.

There are several negative factors which should be taken into account if methanol is to replace gasoline. They are listed as follows : [4]

- low vapor pressure
high heat of vaporization
o low heat of combustion
corrosivity

The low vapor pressure and high heat of vaporization combine to make starting difficult. In carburetted engines, formation of a gaseous mixture is not possible without a heating system for the carburetor and suction tube systems.

The low heat of combustion of methanol is due to the oxygen content which comprises $50 \%$ of the methanol molecule. As a result of this, the stoiciometric air requirement is lower which necessitates modifications to the carburetor. Fuel nozzles and fuel pumps must be increased relative to gasoline operation. Of course, fuel tanks must be doubled to provide a range comparible to gasoline.

Corrositivity of methanol can be troublesome particularly in the presence of water. Even certain plastics and aluminum are susceptible to corrosive attack.

Other factors must be accounted for when using mixtures of methanol and gasoline; for example: phase separation and azeotrope formation. Water can cause almost complete phase separation if it is present in quantities as low as $0.5 \%$. Settling will occur and the engine, designed to run on gasoline, will receive a methanol-water mixture instead. Other problems result from the formation of a high vapor pressure mixture which can cause vapor lock problems in current engines.

- Turbine Fuel

Methanol has been shown to be an effective turbine fuel in tests conducted by the Florida Power Commission. The turbine 
operated in the range of $18 \mathrm{MW}$ output. In general, the only negative factor noted was the requirement for higher flow rates to accomplish the same amount of work. Due to the larger volume requirement it is unlikely that methanol will ever be used to replace jet fuel.

- Chemical Feedstock

Methanol can be used in place of many petroleum based feedstocks. By using technology developed by Mobil methanol can be converted into a synthetic gasoline, see Figure 3.8-5. Some other products which can use methanol as feedstock include: MTBE, ethylene, propylene, ethylene glycol, acetic acid, methyl acetate, ethanol, styrene, and ethylbenzene.

\subsection{Other Synthesis Products}

As listed earlier, the major synthesis products include: methanol, ammonia, SNG, synthetic crude, hydrogen, carbon monoxide, and carbon dioxide. Methanol has been discussed in the previous subsection. The remaining major products will be discussed briefly below.

\section{- Ammonia}

Ammonia is formed by the reaction of hydrogen and nitrogen. The air separation plant which supplies the oxygen would perform a double duty by supplying the nitrogen as well, see Figure 3.8-6.

The process to produce ammonia requires that all of the co be catalytically shifted to hydrogen and carbon dioxide. The bulk of the carbon dioxide is typically removed by a conventional acid gas removal system followed by a cold liquid nitrogen wash step prior to the catalytic ammonia conversion. Ammonia is a precursor for urea and ammonium sulfate or can be used directly as a fertilizer.

- SNG

Substitute natural gas (SNG) is primarily methane. It is produced in a methanation reactor by combining hydrogen and carbon monoxide according to the following reaction: (see Figure 3.8-7).

$$
\mathrm{CO}+3 \mathrm{H}_{2} \rightarrow \mathrm{CH}_{4}+\mathrm{H}_{2} \mathrm{O}
$$

The hydrogen to carbon dioxide ratio required for favorable kinetics will obviously be greater than $3: 1$.

Producing methane has advantages over electrical power production using a low or medium BTU gas. One advantage is the 


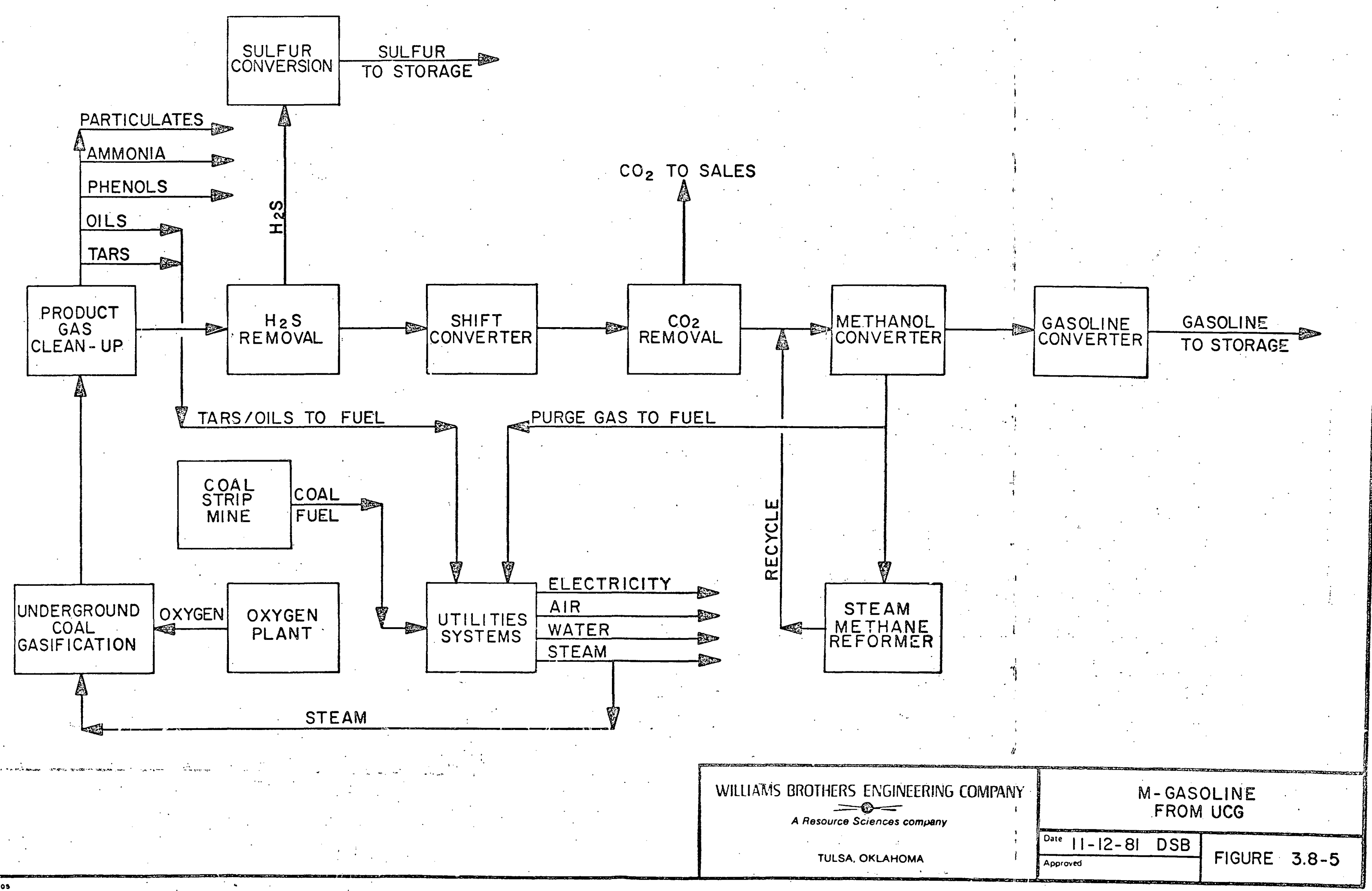




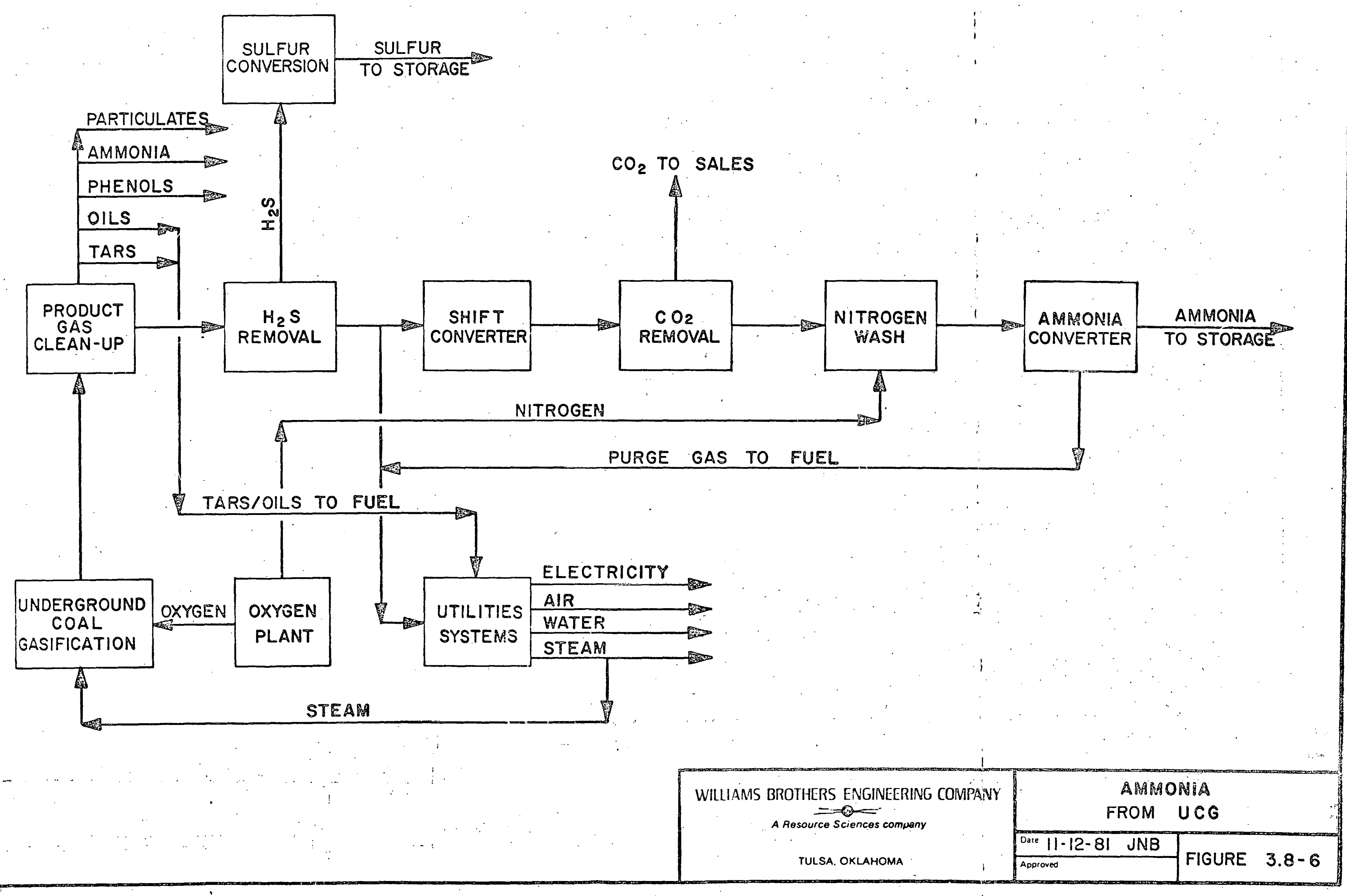




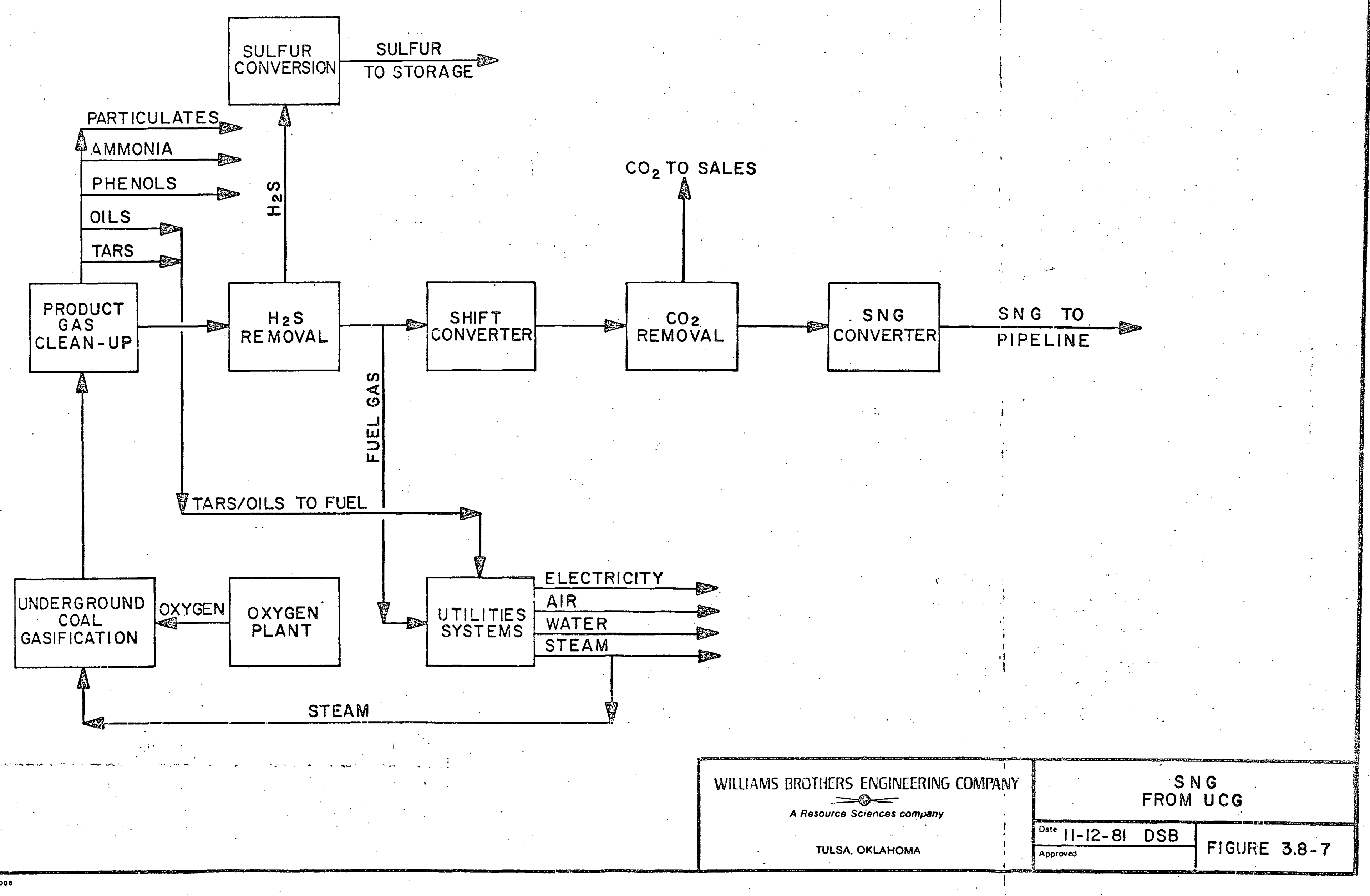


PROCESS ONISION

WHUANS BROTHERS ENGMEERANG COMPAWY

$=$

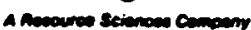

ability to use existing pipeline distribution systems without effecting the natural gas heating value. Another advantage is the distribution to residences and industries where the conversion to heat is direct and will result in much improved thermal efficiencies over the generation of electricity which is at best a $42 \%$ conversion.

- Synthetic Crude

The Fischer-Tropsch Process (F-T) produces a wide range of petroleum-type liquids from syn gas. The process was discovered in the early 1900's and was used to fuel the German military during. World War II. For the past twenty-five years South Africa has been supplementing their crude oil supplies using F-T technology in their SASOL plants.

The major problem with F-T technology has been that it results in a multitude of products. This is becoming less of a problem due to the advent of more selective catalysts and the operating experience which SASOL has acquired. At SASOL II, which has recently started up, $60 \%$ wt. of the output is gasoline. The remainder of the products include: diesel fuel. $(10 \%)$, ethylene $(8 \%)$, alcohols $(4 \%)$, tar products $(8 \%)$, ammonia $(2 \%)$, and sulfur (10\%). Approximately 10,000 tons of product are recovered with an input of 30,000 tons of coal on a daily average. Overall plant thermal efficiency is $55 \%$. [5]

Recent work by Brookhaven National Laboratory, Chem systems, Mobil, and others to develop improved Fischer-Tropsch catalysts will result in greater selectivity than has been heretofore possible. Primary emphasis will be to maximize the straight-chain paraffins under a variety of conditions. [6]

- Hydrogen

The hydrogen produced from a UCG facility can be maximized by shifting all of the carbon monoxide to hydrogen and carbon dioxide. The carbon dioxide formed by the shift can be removed using either standard acid gas removal facilities, hollow fiber membrane technology, or cryogenically.

Hydrogen can be used by refineries to upgrade heavy crudes, coal liquids, and shale oils to high value products. There are three functional areas in which hydrogen performs in a refinery; these are:

$$
\begin{array}{ll}
\text { - desulfurizing } \\
\text { - denitrogenating } \\
\text { - hydrocracking }
\end{array}
$$

As the crude slate of most refineries changes toward the heavier, higher sulfur, and consequently more available 
feedstocks the hydrogen balance of the refinery. normally requires that hydrogen be generated in addition to that amount supplied by the reformer. This increased generation is normaliy obtained by reforming available natural gas, plant fuel gas, or even naphtha stocks. Heavy crude can be hydrocracked to produce a better slate of products than can be obtained by coking if sufficient hydrogen is available.

Refineries which process syncrudes will have an even greater need for hydrogen due to the high nitrogen content of these feedstocks. Nitrogen is a catalyst poison particularly for catalytic reforming and cat cracking. It must be removed to produce stable distillate fuels and to reduce the Nox which would be produced upon burning. To produce a syncrude with $800 \mathrm{ppm}$ nitrogen from oil shale will require about 1350 SCF of hydrogen per barrel. A coal liquid by H-coal technology will use up to 2700 SCFB depending on end products requirements. [7]

\section{- Carbon Monoxide}

Carbon monoxide is a basic building block in synthetic chemistry. It can be recovered from either LBG or MBG using the COSORB process.

The COSORB process selectively extracts carbon monoxide through formation of a complex with cupreous aluminum chloride.

\section{- Carbon Dioxide}

Carbon dioxide is becoming a desirable product for use in enhanced oil recovery (EOR). There are many areas of the world where the viscosity of the heavy oil can be reduced in situ using carbon dioxide.

Carbon dioxide can be separated from LBG or MBG cryogenically or in a 2-stage absorption process.

The amount of carbon dioxide formed is a function of the inefficiency of the gasifier. In wet coals, such as lignite, carbon dioxide might be the principle product with the by-product flammable gas used only to provide on-site power requirements.

\section{- Miscellaneous Products}

The main purpose of the air separation plant, as shown in Figure 3.8-1, is to provide oxygen for gasification. However, five by-products (Nitrogen, Neon, Argon, Krypton, and Xenon) can also be provided by the separation plant. Nitrogen may be used for inerting and for enhanced oil recovery. Argon has applications in the steel industry. Krypton and Xenon are used in the manufacture of high intensity lamps and headlights. 
In the gas processing plant, hot raw UCG gas is washed, cooled, and treated. During this processing, several by-products can be extracted: ammonia, tars/oils and sulfur. Ammonia is used directly as a fertilizer or as a solid fertilizer precursor. Sulfur is used in the manufacture of sulfuric acid and recently as a road building material. Tars/oils, a by-product of UCG, has potential application as a supplement to fuel oil. It may be either fired directly or blended with other fuel oil and then fired. The tars/oils produced could provide a portion of the on-site fuel requirements. 


\section{REFERENCE LIST}

SECTION 3.8 .1

1. R. T. Waibel, E. S. Fleming, "Development of Combustion Data to Utilize Low-Btu Gases as Industrial Process Fuels", DOE Contract NO. EX-76-C-01-2489 FE-2489-48, August, 1979 .

2. J. M. McCrank, F. R. Short, "Power Generation from Shale Oil Process off-Gas", ASME Technical Division Publication, Presented at the IEEE-ASME Joint Power Generation Conference in Buffalo, N.Y., sept. 19-22, 1976.

3. M. D. Henderson, "UCG Fuel for Intermediate-Load Power Plants", Proceedings of the Seventh UCG Symposium, Presented at Fallen Leaf Lake, CA on Sept. 8-11, 1981.

4. "On the Trail of New Fuels: Alternative Fuels for Motor Vehicles", Federal Ministry for Research and Technology, German Text, 1974.

5. J. Benefiel, M. Fassett, "Economics and siting of Fischer-Tropsch Coal Liquefaction," DOE/ET/2625-9.

6. Chemical Week, Page 24, August 26, 1981.

7. R. F. Sullivan, D. J. O'Rear, H. A. Frumkin, B. E. Stangeland, "Refining of Syncrudes", Chevron Research Co., Dept. of Energy Sponsorship. 
WHUWMS BROTHERS ENENEERUNG COMPANY

$$
\Longrightarrow
$$

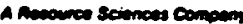

\subsubsection{Potential UCG Markets}

A detailed market evaluation of the type which will be required to develop a comprehensive strategy is beyond the scope of this report. However, preliminary information indicates that there is currently or will soon be a large potential market for UCG derived products in the United States and in the East-NorthCentral United States, in particular. Furthermore, the markets include, in descending order of probable adoption, the following users :

- Single-user LBG or MBG utilities on-site

- Single-user LBG industrial plants near site $1<10$ miles)

- Single and multiple-user MBG industrial plants off-site

- Single-user MBG utilities off-site

- Multiple-user methanol for vehicle fleet and peaking power generation off-site

- Multiple-user LBG industrial near site.

The primary driving force for acceptance of coal derived gas as a fuel and feedstock is the predicted shortfall of energy supplies to energy requirements. While current supplies of natural gas appear plentiful, long-range projections predict that new gas discoveries will not keep up with requirements. Price increases for oil and gas will predictively continue to exceed the rate of inflation. In addition, as long as the U.S. is not energy self-sufficient, the threat of politically motivated curtailment is always possible.

Factors which will promote the use of UCG over surface gasifier technology in the Eastern United States, in particular, include:

Regulatory Factors:

- Clean Air Act - This act of Congress adds more to the cost of using higher sulfur coal than to the cost of using low sulfur coal.

- Coal Mines Health and Safety Act - This act of Congress protects the health and safety of miners. It also reduces the productivity of miners and thus increases the cost of coal. 
PROCESS DIVISION

WILUAMS BROTHERS ENGINEERING COMPANY

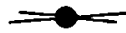

A Resource Scionces Compenty

- Surface Mines Reclamation Act - This act of Congress protects the environment. It raises the cost of mining coal in the process.

- Deregulation of Railroads - Higher prices for transporting coal will raise the price of delivered coal.

Other Factors:

- Environmental

- High cost of ash disposal

- High cost of cleaning coal

- High cost of fuel gas desulfurization.

- Transportation of Gas

- Pipeline transportation cost relative to the value of delivered product.

The negative factors which will limit the rate of adoption of UCG derived gases are similar to the factors which limit coal gasification in general. Among these factors are the following:

- Uncertainty over government involvement

- Lack of operating experience

- Environmental regulations

- Transport of product from coal field to end user

- Uncertainty over conventional fuel supply forecasts

- Large capital investment requiring shared risk or, in the case of utilities, the need for a substantial rate hike to offset new capital expense

- Current lack of clear economic advantage and the perception that alternate fuels will always be more expensive than conventional fuels.

Factors which will influence the adoption of UCG technology in the Eastern United States include:

- The terrain which varies from alluvial flatlands to high relief contour hill country, 
- The labor unions who may view UCG as competing for coal supplies with conventional labor intensive underground mining technology, and

- The negative psychological impact caused by existing coal seam fires which have burned out of control for many years creating an environmental and safety hazard.

\subsubsection{Product Demand}

The future demand for clean fuels and chemical feedstocks in the United states is sufficient to justify development of UCG technology. This demand will result from the growth of new utility power and industrial plant requirements, and the decline of conventional fuel and feedstock availability.

Favorable economics are absolutely essential to acceptance. The potential for mitigating environmental, social, and health effects of conventional mining should provide the incentive to continue to develop UCG technology in the Eastern United states as an option to surface gasification.

Fuel and Feedstock Availability

Even though price increases for energy supplies since 1973 have been substantial, the increase has not been sufficient to reverse the trend toward lower proved reserves of conventional fuels in the United States, see Table 3.8-2. In addition, while the recent trend has been toward a lower rate of energy consumption, the trend is nevertheless upward, see Table 3.8-3. Coal output has increased over three quads since 1972 and as such is the leading contender for the new energy market, see Table 3.8-4. Nuclear energy which was to have supplied the lion's share of the market has dropped to second place with 2.5 quads of new output. Antinuclear sentiment is expected to keep nuclear plant start-ups down in the future and the pressure on coal to fill the gap.

Most of the coal will need to come from the western states of Wyoming and Colorado which contain thick, strip minable, low sulfur coal. The problem is one of transporting the coal to markets. The railroads currently have a monopoly on moving coal although slurry pipelines may soon remedy that, if sufficient water can be found and legal hurdles can be cleared.

An alternative to western coal, in some areas of the country, would be to try to utilize local energy resources. High sulfur, underground mined coal is at an economic disadvantage when environmental and safety controls are imposed. Even the front-end costs of mining continue to increase as the productivity declines, see Figures $3.8-8$ and 3.8-9. When New 
TABLE 3.8-2

U.S. PROVED ENERGY RESERVES: NATURAL GAS OIL, AND NATURAL GAS LIQUIDS [5]

\begin{tabular}{|c|c|c|c|}
\hline & Natural Gas & Crude Oil & Natura1 Gas Liquids \\
\hline & million $C F$ & $1000 \mathrm{bb} 1$ & $1000 \mathrm{bbl}$ \\
\hline $12-31-70$ & $290,746,408$ & $39,001,335$ & $7,702,941$ \\
\hline $12-31-71$ & $278,805,618$ & $38,062,957$ & $7,304,227$ \\
\hline $12-31-72$ & $266,084,846$ & $36,339,408$ & $6,786,559$ \\
\hline $12-31-73$ & $249,950,207$ & $35,299,839$ & $6,454,707$ \\
\hline $12-31-74$ & $237,132,497$ & $34,249,956$ & $6,350,449$ \\
\hline $12-31-75$ & $228,200,176$ & $32,682,127$ & $6,267,830$ \\
\hline $12-31-76$ & $216,026,074$ & $30,942,166$ & $6,401,967$ \\
\hline$[6] 12-31-76$ & $213,278,000$ & $33,502,000$ & \\
\hline $12-31-77$ & $208,877,878$ & $29,486,402$ & $5,994,365$ \\
\hline$[6] 12-31-7]$ & $207,413,000$ & $31,780,000$ & \\
\hline $12-31-78$ & $200,301,707$ & $27,803,760$ & $5,925,852$ \\
\hline$[6] 12-31-78$ & $208,033,000$ & $31,355,000$ & $6,772,000$ \\
\hline $12-31-79$ & $194,916,624$ & $27,051,289$ & $5,655,323$ \\
\hline [6]12-31-79 & $200,977,000$ & $29,810,000$ & $6,615,000$ \\
\hline
\end{tabular}$$
200,977,000
$$ 


\section{PROCESS OMISION

TABLE $3.8-3$

U.S. ENERGY CONSUMPTION

$\frac{\mathrm{DOE}^{[7]}}{10^{15} \mathrm{BTU} / \mathrm{yr}} \cdot \frac{\mathrm{DOE}^{[9]}}{{ }^{[8]}}$

1971

68.30

1972

71.643

71.63

1973

74.609

74.61

74.61

1974

72.759

72.76

72.76

1975

70.707

70.71

70.71

1976

$74.510 \mathrm{r}$

74.51

74.51

1977

$76.332 r$

$76.33 r$

76.39

1978

$78.150 \mathrm{r}$

78.15

78.15

1979

78.968

$78.97 \mathrm{r}$

78.02p

1980

76.201r 76.27p

$\mathrm{p}=$ preliminary

$r$ = revised

1 


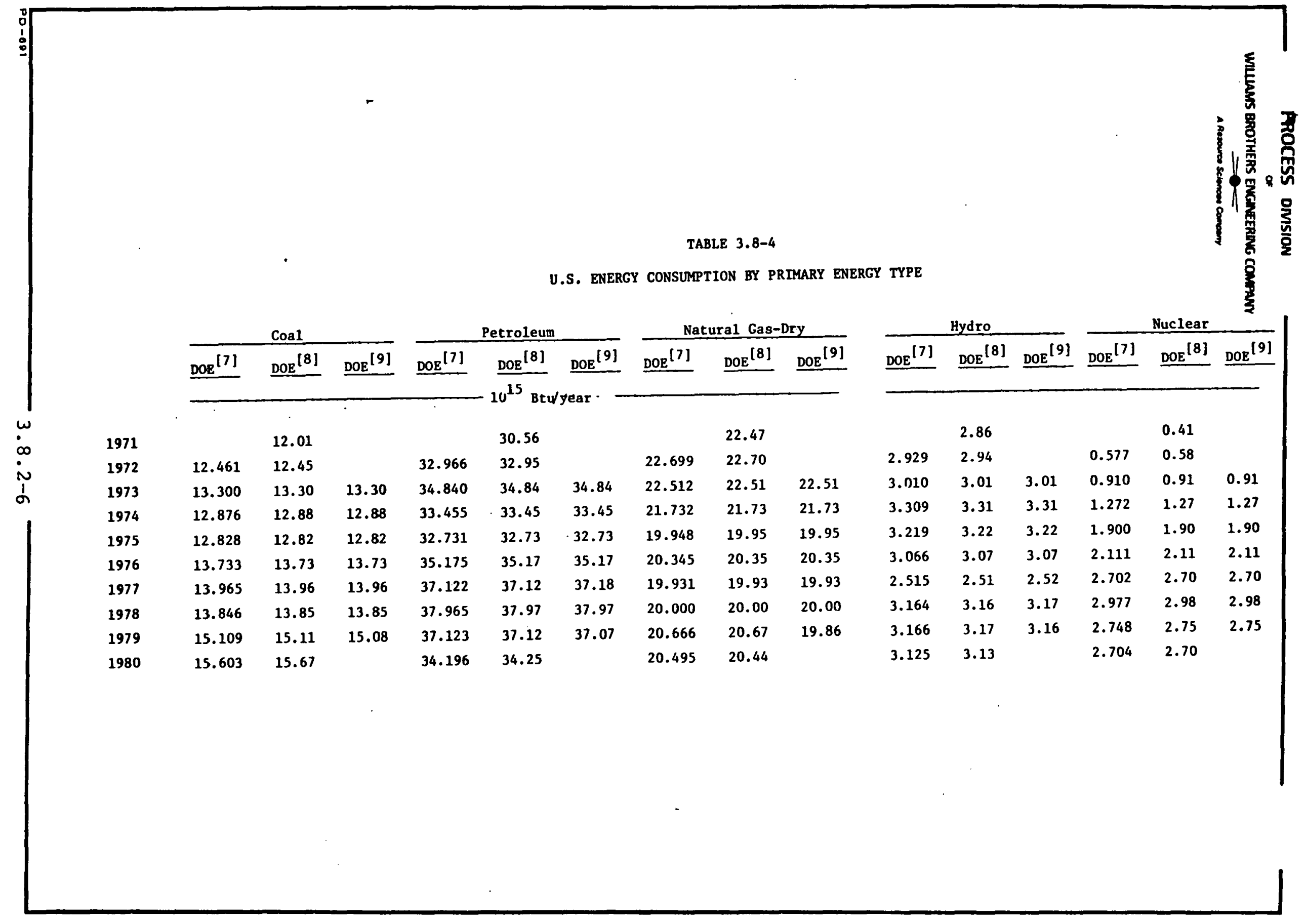




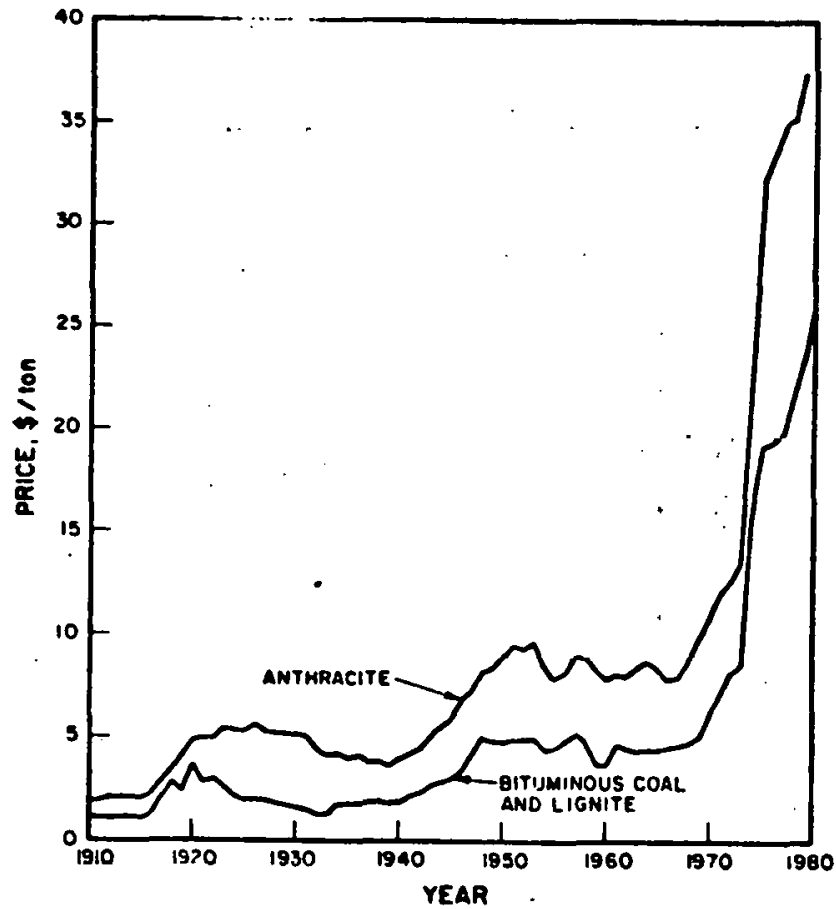

WILLAMS BROTHERS ENGINEERING COMPANY

A Resource Sciences compary

TULSA, OKLAHOMA

Average Price of Coal

(In current dollars)

Dote

Figure 3.8-8 


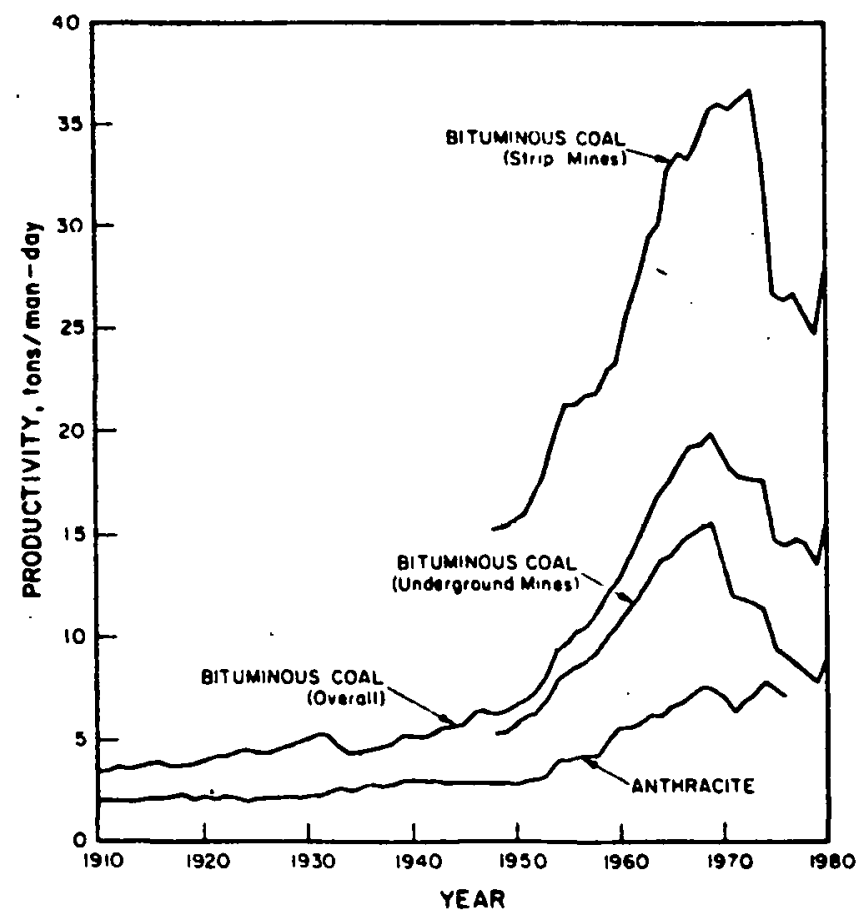

WILLIAMS BROTHERS ENGINEERING COMPANY

A Resources Scioncos compeny

TULSA, OKLAHOMA

Productivity.. Per Man Day in Coal Mining

\begin{tabular}{|l|l|}
\hline \multicolumn{2}{|c|}{ Mining } \\
\hline Date & Figure 3.8-9 \\
\hline
\end{tabular}




\section{PROCESS DMSION}

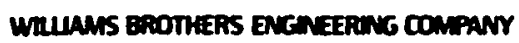

A

Source Performance standards (NSPS) of 1979 are fully applied, Illinois Basin coal will suffer a $\$ 0.40$ per million Btu penalty over lower sulfur coal; this adds about $\$ 9$ per ton to the cost of using coal.[10]

A method of utilizing the high sulfur coal without the economic disincentives associated with coal washing and flue gas desulfurization might be to gasify it in situ and utilize a relatively inexpensive acid gas clean-up on the surface. Using UCG technology, much of the sulfur would never even leave the seam. Coal and ash handling problems would be essentially eliminated.

\section{Product Price Estimation}

This contract did not include funds to determine a product price beyond estimating the combined linking and well costs per million Btu of gas produced for the purpose of comparing alternate linking concept strategies. Therefore, only a brief attempt to estimate the price is made using the available open literature.

Prices predicted in the literature for product from UCG vary extensively. Estimates for UCG product from thin bituminous coal are almost non-existent. However, if one assumes that bituminous coal will be as easy to gasify as subbituminous coals, once the permeability has been established by using specific technologies such as directional drilling, then it should be reasonable to extrapolate the literature estimates down to the seam thicknesses of most bituminous seams. There are several factors, none of which are well understood, which might balance out any discrepancies in this assumption; namely, the relative competance of the overburden of deeper seams in the Eastern United States, the higher heating value of the coal and the potential for minimal water influx. A range of price for LBG or MBG from $\$ 2.90$ to $\$ 5.70 /$ MMBTU (50\%-65\% Equity Basis) can be inferred by combining information provided in several studies and scaling the prices to 1980 dollars [26][27][28][29]. No distinction can be made between LBG and MBG price requirements since some studies show LBG to be costlier and in others MBG is the more expensive. This method is obviously subject to error; however, it does point out the possibility that the products of UCG may be competitive with fuel oils and naphthas.

The price is highly dependent on the type of financing, oxygen utilization efficiency, well spacing, and sweep width. In the Phase II report, the cost of linking and well preparation per million BTU's was evaluated for various linking concepts. For the Open Borehole concept, a simple cost from $\$ 1.31$ to

$\$ 5.16 / \mathrm{MMBTU}$ was determined in varying the thickness from 8 to 4 feet at a depth of $500 \mathrm{ft}$. The sweep was assumed to be equal 
to ten times the coal seam thickness and the well spacing at $150 \mathrm{ft}$. Assuming $\$ 3.00 /$ MMBTU for field piping plus a processing facility, a total cost of $\$ 4.31$ to $\$ 8.16 / \mathrm{MMBTU}$ results. of course, interest, depreciation, rate of expenditure, and rate of return all need to be accounted for to arrive at a true DCF value. By doubling the well spacing to $300 \mathrm{ft}$., the well cost would be reduced by $\$ 0.32$ to $\$ 1.26 / \mathrm{MMBTU}$ for a new range of $\$ 3.99$ to $\$ 6.90 / \mathrm{MMBTU}$. The greater well spacing has an obviously more pronounced effect on the thinner $4 \mathrm{ft}$. seam than on the $8 \mathrm{ft}$. seam.

\section{Utility Power Demand}

LBG and MBG can be used to fuel conventional power plants without a requirement for coal cleaning, flue gas

desulfurization or ash disposal. While direct substitution for coal in power boilers is technically feasible, the most likely use of LBG will be in intermediate load gas turbines located at the UCG facility.

Utility power growth is projected to be about $3.4 \%$ per year between now and 1990, see Table 3.8-5. This is about $1 / 2$ of the $6 \%$ per year growth rate which occurred between 1940 and 1973. Most of the new base load increase will be met with new coal production rather than nuclear energy as once predicted. Increased coal use will result in an increase in environmental problems, such as: atmospheric contamination with sox, NOx, and particulates; and surface landfill requirements for coal ash. Much of this environmental problem can be mitigated using UCG technology.

TABLE $3.8-5$

U.S. ELECTRICITY DEMAND

$10^{15} \mathrm{BTU}$ 's/Year [1]

$\underline{1979} \underline{1985} \underline{1990}$

$\begin{array}{llll}\text { Residential } & 2.40 & 2.9 & 3.3\end{array}$

$\begin{array}{llll}\text { Commercial } & 1.77 & 2.1 & 2.5\end{array}$

Industrial $\quad \underline{2.88} \quad \underline{3.6} \quad \underline{4.4}$

$\begin{array}{llll}\text { Total } & 7.05 & 8.6 & 10.2\end{array}$

Along with the increase in base load, new intermediate and peak load requirements will need to be met. The intermediate and peak load requirements are typically $30 \%$ and $20 \%$ of the total 


\section{PROCESS ONISION}

WMUNus BROTHERS ENGNEERTG COMPANY

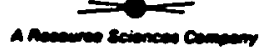

installed capacity. This should result in increased requirements of approximately 1 quad for intermediate and 0.6 quad for peaking power by 1995. Just to meet the intermediate require-

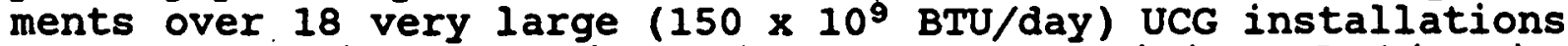
would be required. It is unlikely that a facility of this size would be built outside of the western states. In the Eastern United states, facilities down to 2-3\% of that size may actually be developed which would be sufficient to supply a $25 \mathrm{MW}$ facility $\left(230 \cdot 10^{6} \mathrm{BTU} / \mathrm{hr}\right)$.

The Fuel Use Act of 1978 precludes the use of fuel oil and natural gas in combined-cycle plants for intermediate load service and restricts their use to peaking requirements (less than 1500 hours per year) [2]. LBG is not restricted from such use. In fact, it would be more suited for intermediate load service than for peaking use which requires response to a cyclic load.

The advantages of using a combined-cycle or cogeneration unit result principally from the higher efficiency and the lower cost per unit of capacity. If the waste heat generated steam can be used to help process the UCG gas, the efficiency of power generation can be as high as $80 \%$. A coal derived gas, such as LBG, should be utilized at the highest possible efficiency to optimize the economics.

MBG can be used in existing oil and gas fired power plants with minimum to no derating.[3] provided the penalty for transporting MBG is not excessive, this use may provide the type of load requirement needed until higher value uses develop.

\section{Industrial Plants Demand}

Industrial plants can utilize UCG products to both supply their heating and internal power requirements, and as feedstock for chemical products manufacturing. LBG will require that an industrial park be established near the UCG facility or that one very large consumer develop a field as a captive supply. MBG is suited to distribution to a limited number of users.

Currently, there are twenty surface-type coal gasifiers which are in operation or under construction which will be used to provide fuel to industrial plants. Ten of these will be to single-users. [4]

The fact that the market for coal derived gases is large enough to justify development of the industry was recently determined in a government sponsored study. [4] This study concluded that the industrial market for LBG and MBG exceeds three quads. A potential exists for 3500 single-user LBG plants, 550 single- ... user MBG plants, and 300 multi-user MBG plants. Early adopters 


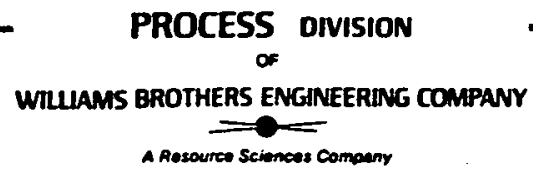

were concluded to be principally the steel, chemical, and brick companies.

A further incentive for the use of cogeneration by industrial firms has recently been provided by the Public Utility Regulatory Policy Act (PURPA). Section 210 of PURPA, promulgated by Congress in March 1980 and administered by the Federal Energy Regulatory Commission (FERC), eliminates regulatory and economic obstructions to industrial cogeneration by requiring utilities to purchase cogenerator electricity at the utilities "avoided cost". A utility must, therefore, pay the cogenerator what it saves by not generating the energy itself from its most expensive facility, either by increasing power output or adding to capacity. Utilities are furthermore limited to a 50\% ownership in the facilities. In addition, industrial cogenerators are eligible for a $10 \%$ tax credit on all energy saving equipment. The utilities are not exactly pleased with the limitations imposed on them by Purpa. State plans for implementation of the act were due March 20, 1981.

\section{Synthesis Products}

Certain synthesis products might best be produced at the UCG site to optimize energy efficiency and to improve economics of transporting product to market. Only the largest UCG facilities projected for the East will be sufficient to carry the cost of additional process units on-site. While the future cost of natural gas might dictate production of ammonia and urea, or SNG as viable UCG based products, current potential for new transportation fuels makes methanol attractive.

Energy efficiency should be a principle consideration to assure maximum utilization of natural resource. The primary product of coal gasification contains hydrogen and carbon monoxide. It makes little thermodynamic sense to convert this gas to methane. just to move it, then reconvert it to hydrogen and carbon monoxide at some remote location to make a synthesis product. Locating the site near a petrochemical complex, within the economic transport radius of a medium Btu gas, will make better use of the resource.

Using UCG derived gases as synthesis feed gas rather than fuel has merit.. other energy sources, i.e., nuclear, low sulfur coal, geothermal, etc., might be better suited to fuel the utilities due to the inherently low conversion efficiency $(30-42 \%)$ to electricity. Conversion to SNG makes sense from the standpoint that, as a fuel which can be used in residence, methane may eventually become too valuable to be used to generate base load power. 
WRUMUS BROTHERS ENGNEERNG COMPAYY

Anom

\section{Methanol Markets}

Methanol has much to offer as a fuel and petrochemical feedstock. Economic studies have indicated that when produced in sufficiently large scale facilities methanol can be competitive with gasoline. But, before methanol can be produced in large scale projects, a market needs to be assured. Recent actions in the United states and in Europe are leading in this direction.

Fuel uses for methanol include both internal combustion and gas turbine options as previously discussed in section 3.8.1. Chemical uses include feedstock for higher homologs and solvents.

The current U.S. market for methanol is approximately $3.4 \mathrm{MM}$ m.t. By 1990, the market is expected to exceed $8 \mathrm{MM} \mathrm{m} . t$. [11] Essentially all of this methanol is projected to be used as chemical feedstock with minimal use as a fuel. Should methanol be used to replace gasoline, the market could be many times greater than projected capacity.

Gasoline consumption in the U.S. dropped dramatically starting in 1978 when deregulation allowed prices to rise to import levels. A total drop of $8.9 \%$ across the U.S. during 1979 and 1980 reversed a trend which had increased gasoline consumption $3.5 \%$ per year the previous four years.[12] The price of gasoline, however, is expected to continue to increase at a rate exceeding the cost of living. Thus, even while demand is down for gasoline the economic driving force for a substitute fuel has rarely looked better.

However, substituting methanol for gasoline will not be an overnight proposition. To gain acceptance as a gasoline replacement, methanol will need to be tested under fleet conditions. Only recently have automobile manufacturers begun to build large numbers of test vehicles specifically designed to burn methanol. The California Energy Commission, anxious to reduce exhaust emissions and avoid another gasoline shortage, has purchased 40 Volkswagon Rabbits and 40 Ford Escorts equipped to burn methanol. The three-year $\$ 2 \mathrm{MM}$ project, if successful, may result in the conversion of the state fleet of 15,000 cars to methanol. [13]

Blends of gasoline and methanol do not have all the advantages of methanol alone. The additional disadvantages of high vapor pressure and phase separation are significant disincentives. Other ways of introducing methanol to the transportation industry might initially be through conversion to methyl tertiary butyl ether (MTBE), an octane enhancing additive, which does not suffer the limitations of methanol-gasoline blends. However, the size of the market for MTBE is difficult 


\section{PROCESS DIVISION}

WILLAMS BROTHERS ENGINEERING COMPANY

$=$

A Resource Scromoses Compeny

to project. The production of unleaded-only engines and the higher compression ratios of these engines has increased demand for octane number. Conversely, the soft gasoline market should make more octane barrels available. But, even as the first MTBE plants are coming on-line, the average octane numbers of regular and premium gasolines are dropping.

A recent study [14] points up the difficulty methanol may face in replacing gas as a peaking fuel. Regulatory uncertainity over the use of methanol instead of gas may hold up utility fuel switching. By 1990, utility methanol demand, it is predicted, will total only $54 \mathrm{MM}$ gal/yr. Another paper [15] takes a somewhat regional view of Los Angeles and other smog-prone areas when it claims that the utility gas turbine is the "key" to successful methanol marketing. They are secure, stable, and centralized. As a case in point, southern California Edison has announced its intent to burn methanol as soon as it becomes available in reliable quantities.

Other new, potential markets for methanol while not as important as the fuel use of methanol, may help to build capacity; these markets include conversion of methanol to M-gasoline, treatment of acid gas with refrigerated methanol, feedstock for protein production, fuel cell fuel, and mixtures of methanol and coal.

A huge potential user market will not be enough to assure acceptance, the price must also be competitive.[16] [17] Several studies have indicated that methanol when produced in large enough quantities can have a price parity with existing fuels; particularly, when a reduction in environmental control requirements and efficiency improvements are accounted for. While most of these studies have been based on conventional coal gasifiers, other studies have shown that UCG can be more economical than a surface based system [18][19].

Prices vary significantly with capacity. Various studies were used to produce. Table 3.8-6 which indicates that prices in 1981 dollars can be expected to drop from $\$ 0.99 /$ gallon to $\$ 0.28 / g a l i o n$ when the capacity increases from $4000 \mathrm{~B} / \mathrm{D}$ to $415,000 \mathrm{~B} / \mathrm{D}$. A study by Davy McKee Corp. [20] indicates that the cost of producing 5000 ton/day methanol will be $\$ 0.80$ per gallon using either $\$ 1.75 /$ MMBtu coal $(\$ 30 /$ ton) or $\$ 5.00 /$ MMBtu natural gas.

In order to understand the equivalent price for methanol, one must take into account the relative energy contents and efficiency of use. Methanol has only $45 \%$ of the combustion energy present in gasoline, but could give overall efficiencies 45\% higher than gasoline when compression ratio and pollution controls are accounted for. [24] Therefore, at $\$ 1.03$ per gallon for premium, unleaded (wholesale), methanol would need to sell 


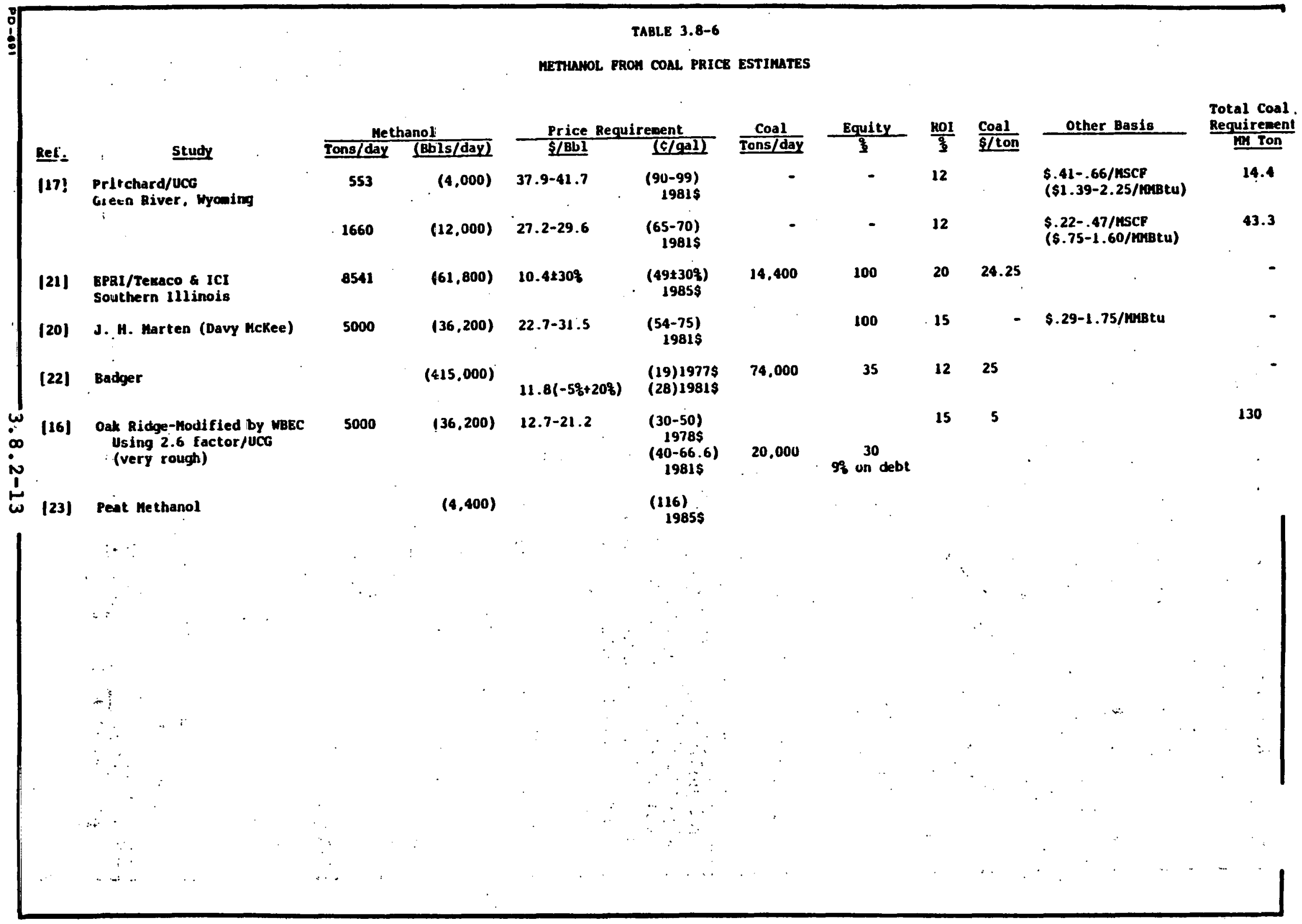


WRULAMS BROTHERS ENGINEERING COMPANY

$=0$

for $\$ 0.67$ per gallon at the plant gate. With the exception of the two cases under $5000 \mathrm{bbls}$. per day all estimates in Table 3.8-6 are economically acceptable.

\subsubsection{Regional Demand}

Areas of the country where the net energy flow is projected to be inward, or where the cost of energy is highest, are good candidates for new energy sources. If UCG amenable coal resources are located within these energy poor areas, UCG technology should be able to offset at least part of the import demand.

The East-North-Central United states has both high projected energy demand and a base of coal potentially amenable to UCG. The East-North-Central demand region, as defined by the Census Bureau, contains Ohio, Indiana, Illinois; Wisconsin, and Michigan. Illinois and Ohio both have UCG target areas which were identified in the site selection section.

\section{Energy Balance}

As indicated in Table 3.8-7, the region of the country which imports the greatest quantity of energy is the

East-North-Central census region. (The census regions are defined in Figure 3:8-10.) This region contains over 9 billion tons of coal potentially amenable to UCG recovery.

There are advantages to using UCG on higher sulfur content coals as well as higher ash content coals. The average sulfur content of mined coal in 1978 in Illinois and Ohio was 3.1 and $3.4 \%$, respectively. Figure 3.8-11 illustrates the sulfur levels of major coal shipments by state in 1978 .

Acid (low pH) rain has been a problem in the Northeast United states and Southeast Canada for quite some time. Many of the lakes no longer support aquatic life. While no strong correlation has been determined between the coal sulfur content of the coal burned in the East-North Central United states and the $\mathrm{pH}$ of rainfall in the effected areas, it is reasonable to suspect that some of the acidity is directly a result of the high sulfur content of the coals. UCG technology could be instrumental in reducing atmospheric sulfur dioxide if high sulfur coal burned directly could be replaced with clean UCG derived fuel gas.

A comparison of the energy balances for the four states with UCG target areas is presented in Table 3.8-8. As shown, Illinois and ohio import over 2 quads each while Kentucky and West Virginia are net exporters. While it is likely that Kentucky and West Virginia could use UCG product to offset some 
Ref. [30]

TABLE $3.8-7$

PROJECTED NET ENERGY IMPORTS $10^{12}$ BTU's

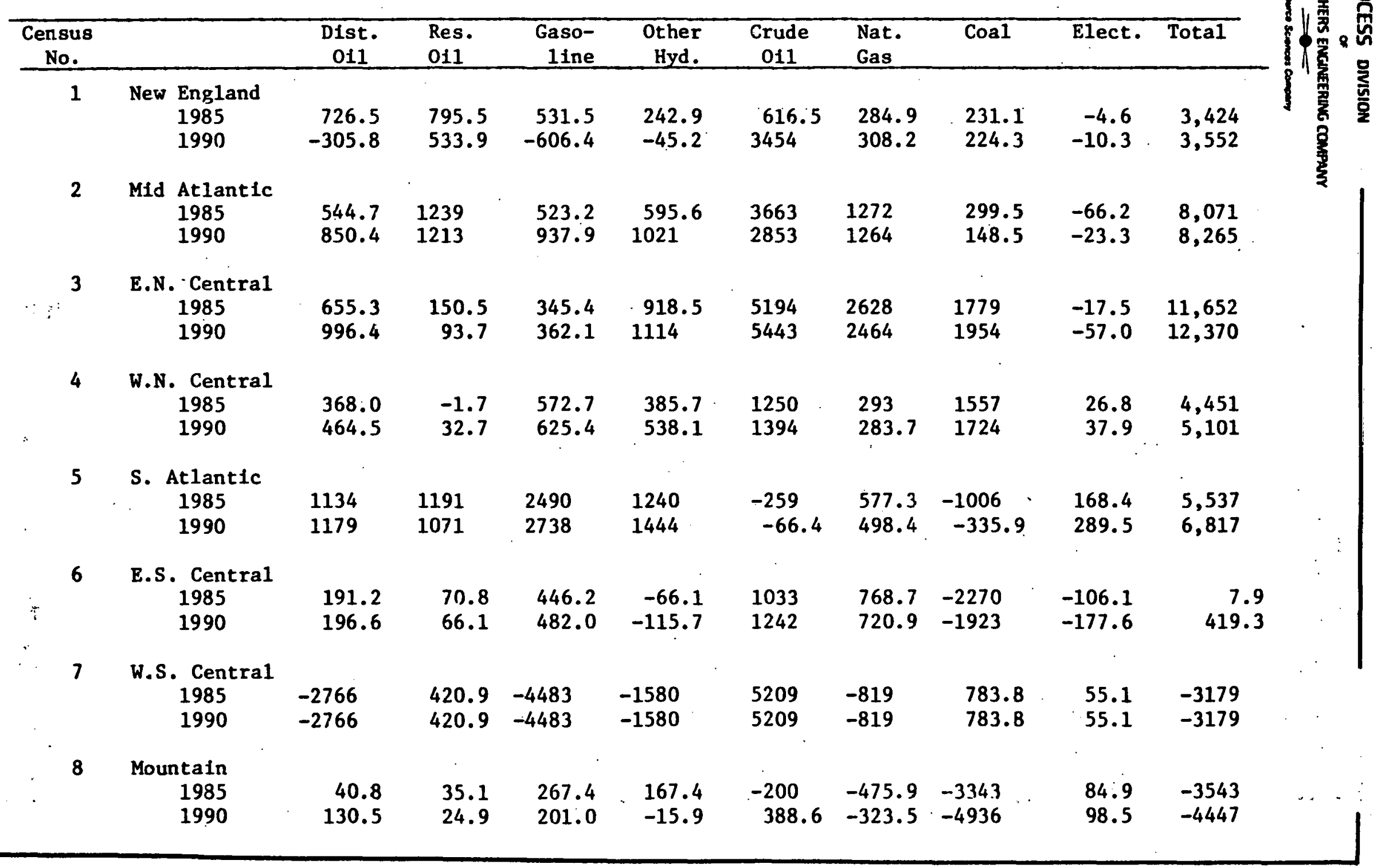


Ref. [30]

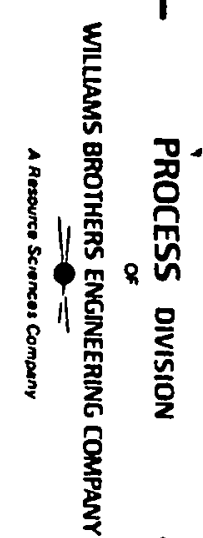

TABLE 3.8-7 (con't.)

\begin{tabular}{|c|c|c|c|c|c|c|c|c|c|c|}
\hline $\begin{array}{c}\text { Census } \\
\text { No. }\end{array}$ & & $\begin{array}{l}\text { Dist. } \\
\text { Oil }\end{array}$ & $\begin{array}{l}\text { Res. } \\
\text { Oi1 }\end{array}$ & $\begin{array}{l}\text { Gaso- } \\
\text { line }\end{array}$ & $\begin{array}{r}\text { Other } \\
\text { Hyd. }\end{array}$ & $\begin{array}{c}\text { Crude } \\
\text { Oil }\end{array}$ & $\begin{array}{l}\text { Nat. } \\
\text { Gas }\end{array}$ & Coal & Elect. & Total \\
\hline 9 & $\begin{array}{r}\text { Pacific } \\
1985 \\
1990\end{array}$ & $\begin{array}{l}-145.8 \\
-114.3\end{array}$ & $\begin{array}{r}-52.9 \\
13.3\end{array}$ & $\begin{array}{l}-364.4 \\
-279.1\end{array}$ & $\begin{array}{r}-157.3 \\
-90.1\end{array}$ & $\begin{array}{r}-40.1 \\
-676.1\end{array}$ & $\begin{array}{l}-2622 \\
-5205\end{array}$ & $\begin{array}{l}50.2 \\
97.0\end{array}$ & $\begin{array}{l}28.9 \\
-7.1\end{array}$ & $\begin{array}{l}-3,303 \\
-6,262\end{array}$ \\
\hline 10 & $\begin{array}{c}\text { United States } \\
1985 \\
1990\end{array}$ & $\begin{array}{l}799.4 \\
799.4\end{array}$ & $\begin{array}{l}3848 \\
3848\end{array}$ & $\begin{array}{l}330 \\
330\end{array}$ & $\begin{array}{l}1747 \\
2884\end{array}$ & $\begin{array}{l}16,465 \\
20,893\end{array}$ & $\begin{array}{l}1907 \\
2089\end{array}$ & $\begin{array}{l}-1918 \\
-2089\end{array}$ & $\begin{array}{l}0 \\
0\end{array}$ & $\begin{array}{l}23,178 \\
29,253\end{array}$ \\
\hline
\end{tabular}




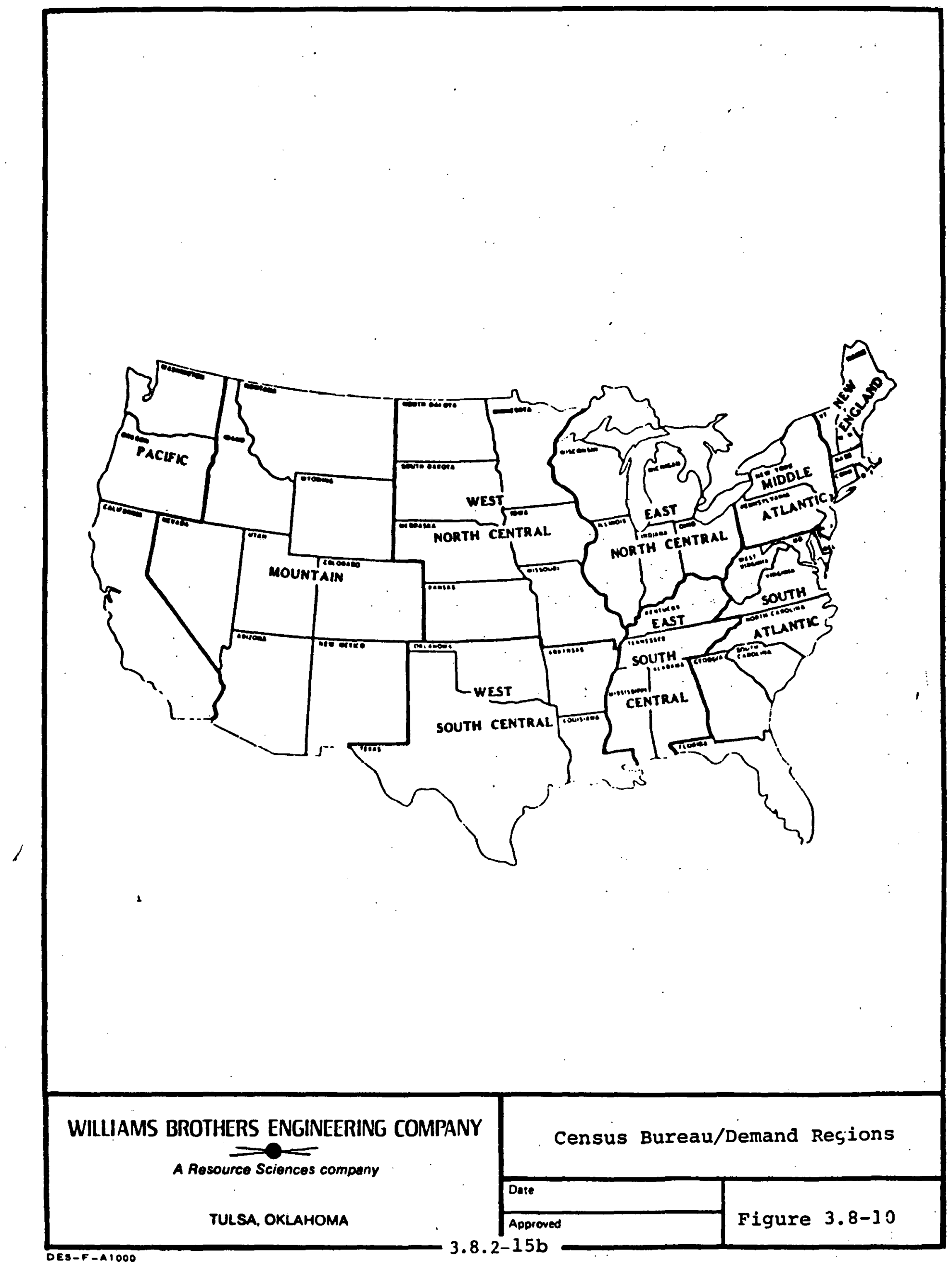




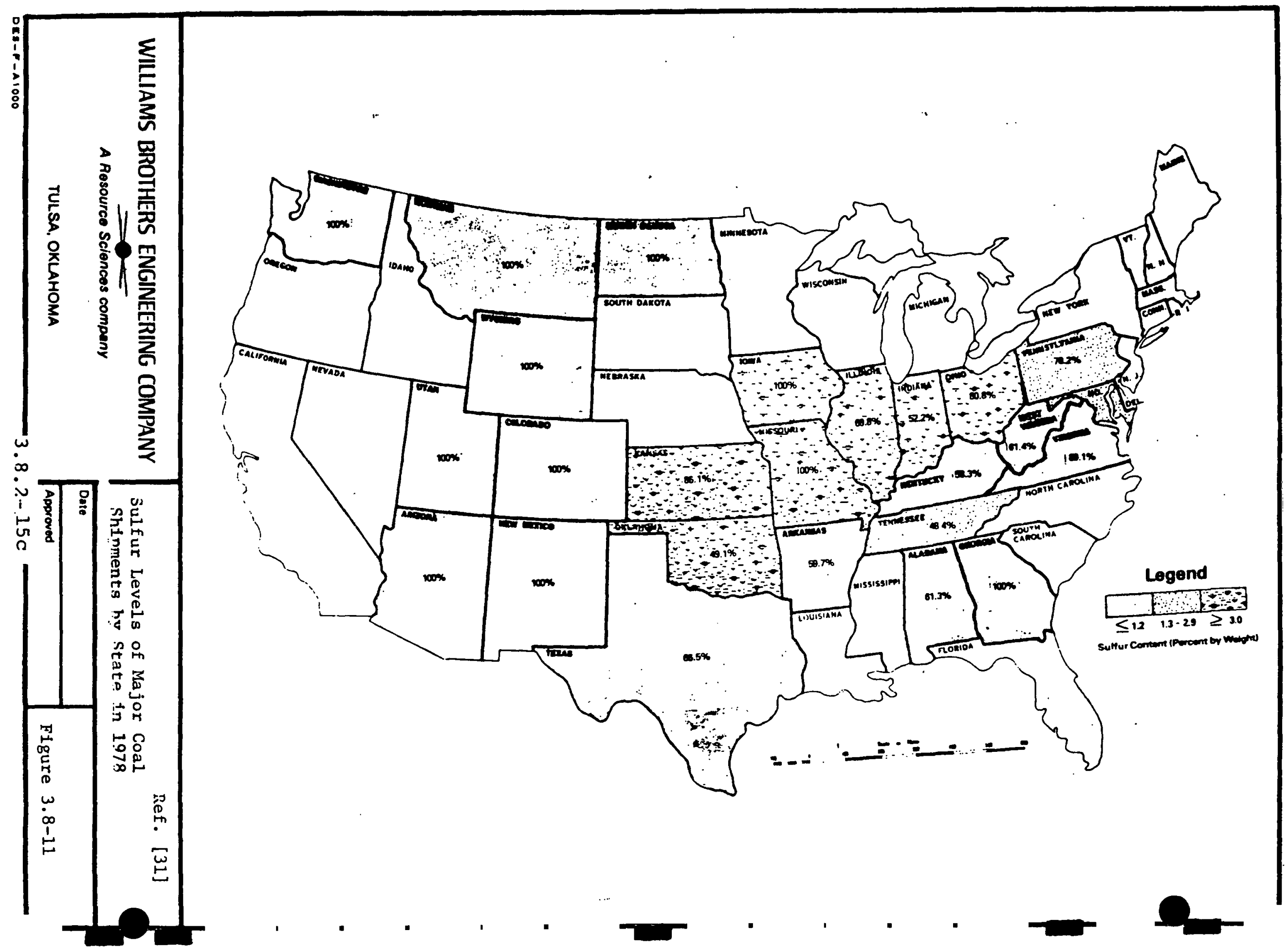


Ref. [30]

TABLE $\mathbf{3 . 8 - 8}$

PROJECTED NET ENERGY IMPORTS BY STATE $10^{12}$. BTU'S

\begin{tabular}{|c|c|c|c|c|c|c|c|c|c|}
\hline State & $\begin{array}{l}\text { Dist. } \\
011\end{array}$ & $\begin{array}{l}\text { Res. } \\
011\end{array}$ & $\begin{array}{l}\text { Gaso- } \\
\text { Iine } \\
\end{array}$ & $\begin{array}{c}\text { Other } . . . \\
\text { Hyd. }\end{array}$ & $\begin{array}{c}\text { Crude } \\
011 \\
\end{array}$ & $\begin{array}{l}\text { Nat. } \\
\text { Gas }\end{array}$ & Coal $\ldots$ & Elect. & Tota1 \\
\hline $\begin{array}{r}\text { I111nofs } \\
1985 \\
1990\end{array}$ & $\begin{array}{l}22.2 \\
68.2\end{array}$ & $\begin{array}{l}-35.2 \\
-55.8\end{array}$ & $\begin{array}{l}-471.9 \\
-534.9\end{array}$ & $\begin{array}{r}-32.9 \\
16.3\end{array}$ & $\begin{array}{l}2481 \\
2622\end{array}$ & $\begin{array}{l}913.0 \\
829.1\end{array}$ & $\begin{array}{l}-675.5 \\
-744.2\end{array}$ & $\begin{array}{r}-70.2 \\
-122.3\end{array}$ & $\begin{array}{l}2,087 \\
2,078\end{array}$ \\
\hline $\begin{array}{l}\text { Ohio } \\
\begin{array}{r}1985 \\
1.990\end{array}\end{array}$ & $\begin{array}{r}46.6 \\
125.1\end{array}$ & $\begin{array}{r}46.2 \\
-41.6\end{array}$ & $\begin{array}{l}143.2 \\
149.5\end{array}$ & $\begin{array}{l}150.2 \\
200.6\end{array}$ & $\begin{array}{l}1182 \\
1233\end{array}$ & $\begin{array}{l}787.5 \\
753.6\end{array}$ & $\begin{array}{l}522.2 \\
549.9\end{array}$ & $\begin{array}{l}-4.1 \\
-3.4\end{array}$ & $\begin{array}{l}2,782 \\
2,967\end{array}$ \\
\hline $\begin{array}{r}\text { Kentucky } \\
1985 \\
1990\end{array}$ & $\begin{array}{l}46.6 \\
58.5\end{array}$ & $\begin{array}{l}-10.1 \\
-13.9\end{array}$ & $\begin{array}{r}86.0 \\
101: 3\end{array}$ & $\begin{array}{r}8.9 \\
17.9\end{array}$ & $\begin{array}{l}310.5 \\
288.9\end{array}$ & $\begin{array}{l}171.9 \\
146.9\end{array}$ & $\begin{array}{l}-3414 \\
-3666\end{array}$ & $\begin{array}{r}-40.5 \\
3.3\end{array}$ & $\begin{array}{l}-2,841 \\
-3,063\end{array}$ \\
\hline $\begin{array}{c}\text { West Virginia } \\
1985 \\
1990\end{array}$ & $\begin{array}{l}38.3 \\
48.4\end{array}$ & $\begin{array}{l}6.9 \\
8.9\end{array}$ & $\begin{array}{r}88.6 \\
104.9\end{array}$ & $\begin{array}{l}27.0 \\
36.5\end{array}$ & $\begin{array}{l}1.9 \\
8.3\end{array}$ & $\begin{array}{l}-2.9 \\
31.0\end{array}$ & $\begin{array}{l}-2607 \\
-2935\end{array}$ & $\begin{array}{l}-96 \\
-76.5\end{array}$ & $\begin{array}{l}-2543 \\
-2773\end{array}$ \\
\hline
\end{tabular}




\section{PROCESS DIVISION}

$\infty$

WILLAMS BROTHERS ENGINEERING COMPANY

$=$

A Rosource Sciences comony

of their liquid or gaseous fuel requirements, Illinois and Ohio appear to have the greater need.

\section{Energy Prices By Region}

In order for a synthetic fuel to be marketable, it must be competitively priced. Certain areas of the country pay more for energy than other areas. If a region has both high prices for conventional fuels and a resource base for an alternate fuel technology, it is a good candidate for use of that technology. The East-North-Central region meets these criteria better than any other region in the country with respect to underground coal gasification.

UCG derived gases could displace a portion of the high sulfur coal currently used to generate power; but until the cost of mining, transporting and cleaning coal, scrubbing the flue gases, and disposing of the ash exceeds the cost of burning oil or gas, it is unlikely that this will happen. Rather, it is more likely that UCG gases will displace oil and gas in certain specific applications. Therefore, those regions where oil and gas are priced the highest and a potential UCG base is located. will be prime potential areas for early commercial development of UCG technology.

The highest priced oil and gas in the country is in the Pacific region followed by the East-North-Central region, see Table 3.8-9. Of these two regions, only the East-North-Central region has identified potential bituminous UCG resources. The Mountain region is the next highest area with identified UCG resources but as indicated earlier in Table 3.8-7 the overall demand is negative there.

As discussed in Section 3.8.2.1 (Product Price Estimation), the price of UCG product from thin bituminous coals is estimated to be between $\$ 2.90$ and $\$ 5.70 /$ MMBTU. The price of coal, even if a $\$ 0.40 /$ MMBTU penalty over lower sulfur coal is incurred due to NSPS requirements, will still be less than $\$ 2.00 /$ MMBTU, see Table 3.8-9. Gas is still less than $\$ 3.00 / \mathrm{MMBTU}$ although in some areas of the country new, deep, deregulated gas (Section 107 of NGPA) is going for up to $\$ 11 / M$ cu. ft. although most new, intrastate gas is in the \$7-9 range [33]. Currently, deregulated fuel oil is delivered in the $\$ 5-6 /$ MMBTU range in the East-North Central United states. Therefore, it appears that UCG gas is almost, if not already, a competitive substitute for fuel oil. Transportation costs may make the difference.

\subsubsection{Transportation Factors}

The distance a product can be transported economically is determined by the total cost of competing products, the price 
TABLE 3.8-9

Ref. [32]

PRICES OF FUELS DELIVERED TO UTILITIES - AUG. 1980

\begin{tabular}{|c|c|c|c|c|c|c|c|c|c|c|}
\hline \multirow[t]{2}{*}{\begin{tabular}{|l|} 
Census \\
District
\end{tabular}} & \multirow{2}{*}{$\begin{array}{l}\text { UCG } \\
\text { Coa1 } 1(2) \\
M \mathrm{M} \text { ton }\end{array}$} & \multirow[t]{2}{*}{ (1) } & \multirow{2}{*}{$\begin{array}{l}\text { Coal } \\
\text { C/MMBTU }\end{array}$} & \multirow{2}{*}{$\begin{array}{c}\begin{array}{c}\text { Fuel } \\
\text { Oil }\end{array} \\
\text { c/MMBTU } \\
\end{array}$} & \multirow{2}{*}{$\begin{array}{c}\text { Natural } \\
\text { Gas } \\
\text { c/MMBTU }\end{array}$} & \multicolumn{2}{|c|}{$\begin{array}{r}\text { Average } \\
\text { Usage } \\
\end{array}$} & \multirow{2}{*}{$\begin{array}{l}\text { Coal } \\
\text { Rank } \\
\end{array}$} & \multirow{2}{*}{$\begin{array}{r}\text { Fue1 } \\
\text { Oi:1 } \\
\text { Rank } \\
\end{array}$} & \multirow{2}{*}{$\begin{array}{l}\text { Nat. } \\
\text { Gas } \\
\text { Rank }\end{array}$} \\
\hline & & & & & & $\mathrm{c} / \mathrm{MM}$ & Rank & & & \\
\hline $\begin{array}{l}\text { New } \\
\text { England }\end{array}$ & $<3.5$ & $\begin{array}{l}\text { High } \\
\text { Avg. }\end{array}$ & $\begin{array}{l}194.6 \\
172.9 \\
\end{array}$ & $\begin{array}{l}677.6 \\
410.9 \\
\end{array}$ & $\begin{array}{l}449.8 \\
345.8 \\
\end{array}$ & 389 & 1 & 1 & 6 & 2 \\
\hline $\begin{array}{l}\text { Middle } \\
\text { Atlantic }\end{array}$ & $<3.5$ & $\begin{array}{l}\text { High } \\
\text { Avg. }\end{array}$ & $\begin{array}{l}180.3 \\
137.2 \\
\end{array}$ & $\begin{array}{l}479.3 \\
440.4 \\
\end{array}$ & $\begin{array}{l}317.5 \\
278.8 \\
\end{array}$ & 236 & 3 & 5 & 4 & 4 \\
\hline $\begin{array}{l}\text { East North } \\
\text { Centra1 }\end{array}$ & 9216 & $\begin{array}{l}\text { Hfgh } \\
\text { Avg. }\end{array}$ & $\begin{array}{l}161.6 \\
146.7 \\
\end{array}$ & $\begin{array}{l}562.1 \\
498.8\end{array}$ & $\begin{array}{l}300.7 \\
291.0 \\
\end{array}$ & 163 & 6 & 4 & 2 & 3 \\
\hline $\begin{array}{l}\text { West North } \\
\text { Centra1 }\end{array}$ & $<3.5$ & $\begin{array}{l}\text { High } \\
\text { Avg. }\end{array}$ & $\begin{array}{l}138.7 \\
111.3 \\
\end{array}$ & $\begin{array}{l}607.1 \\
456.8 \\
\end{array}$ & $\begin{array}{l}242.3 \\
187.2 \\
\end{array}$ & 119 & 8 & 7 & 3 & 7 \\
\hline $\begin{array}{l}\text { South } \\
\text { Atlantic }\end{array}$ & 265 & $\begin{array}{l}\text { High } \\
\text { Avg. }\end{array}$ & $\begin{array}{l}180.0 \\
153.1\end{array}$ & $\begin{array}{r}629.8 \\
387.9 \\
\end{array}$ & $\begin{array}{l}347.2 \\
167.5\end{array}$ & 219 & 4 & 2 & 7 & 9 \\
\hline $\begin{array}{l}\text { East South } \\
\text { Central }\end{array}$ & 1645 & $\begin{array}{l}\text { High } \\
\text { Avg. }\end{array}$ & $\begin{array}{l}183.8 \\
150.1 \\
\end{array}$ & $\begin{array}{l}697.9 \\
344.2 \\
\end{array}$ & $\begin{array}{l}261.6 \\
218.3 \\
\end{array}$ & 158 & 7 & 3 & 9 & 6 \\
\hline $\begin{array}{l}\text { West South } \\
\text { Central }\end{array}$ & 257 & $\begin{array}{l}\text { High } \\
\text { Avg. }\end{array}$ & $\begin{array}{l}195.5 \\
124.8 \\
\end{array}$ & $\begin{array}{r}529.5 \\
367.0 \\
\end{array}$ & $\begin{array}{l}215.4 \\
177.8 \\
\end{array}$ & 168 & 5 & 6 & 8 & 8 \\
\hline Mountain & 20,124 & $\begin{array}{l}\text { High } \\
\text { Avg. }\end{array}$ & $\begin{array}{r}113.8 \\
79.6 \\
\end{array}$ & $\begin{array}{l}697.7 \\
430.8\end{array}$ & $\begin{array}{l}460.9 \\
252.8 \\
\end{array}$ & 107 & 9 & 9 & 5 & 5 \\
\hline Pacific & $<3.5$ & $\begin{array}{l}\text { High } \\
\text { Avg. }\end{array}$ & $\begin{array}{l}141.2 \\
104.4\end{array}$ & $\begin{array}{l}633.2 \\
502.8\end{array}$ & $\begin{array}{l}417.9 \\
353.2\end{array}$ & 393 & 2 & 8 & 1 & 1 \\
\hline
\end{tabular}

Notes: 1. Highs refer to the average of the highest priced state in each district.

2. Bituminous coals only per Appendix B. 
of producing the product, and the cost of transporting it. If it can't be delivered to the customer at a competitive price it will not normally be the fuel of choice: Other factors, such as inflation, environmental considerations, supply assurance, government regulations, guarantees, subsidies, etc. must all enter the equation. It is not an easy task to determine the maximum distance a new product can be moved before the value added causes the product to exceed its market value. However, if we assume that transportation can equal up to $20 \%$ of the cost of producing the fuel a radius of transport can be calculated. It is obvious that when the value of the product increases at a faster rate than the cost of transporting it the radius increases.

As indicated in Figure 3.8-12 the cost of moving a unit volume of gas by pipeline is dependent on the distance as well as on the total quantity to be moved. A large quantity can generally be moved more economically than a smaller quantity. It is evident that if the gas can be sold at the gate for \$5/MMBTU and if a total delivered price of $\$ 6 / \mathrm{MMBTU}$ is competitive the approximate transport radius is 40 miles for LBG at $100 \mathrm{BTU} / \mathrm{SCF}, 100 \mathrm{miles}$ for MBG at $250 \mathrm{BTU} / \mathrm{SCF}$, and $150 \mathrm{miles}$ for upgraded MBG at $350 \mathrm{BTU} / \mathrm{SCF}$. Small quantities of gas (less than 100 MMSCFD) will have a smaller transport radius than those indicated.

The use of existing transportation systems should not be overlooked. It makes good economic sense to use older in-place paid-out systems. However, use of existing modes will require product compatibility.

An extensive network of pipelines exist in the United states for transport of crude, natural gas and petroleum products. Several of these pipelines pass near target areas identified as having coal amenable to UCG. Liquid products, such as, methanol, M-gasoline, or a Fischer-Tropsch crude could potentially be moved in crude or product liquid pipelines. Liquids could also be moved over rails and highways or barged down waterways. SNG could easily be transported in an existing natural gas line.

Could MBG or LBG be transported in a natural gas pipeline? This would depend, in part on the resulting properties of the mixture. Air is routinely added to natural gas in small quantities (below the explosive limit) to dilute the gas and bring it into heating value specification. The effect of blending hydrogen, carbon monoxide and carbon dioxide into a natural gas line may not be compatible with pre-existing end-uses particularly in the chemical industry. The effect of a toxic gas such as carbon monoxide being introduced into residential uses also may not be acceptable; although, 'town gas', which contains carbon monoxide, has been used in this 


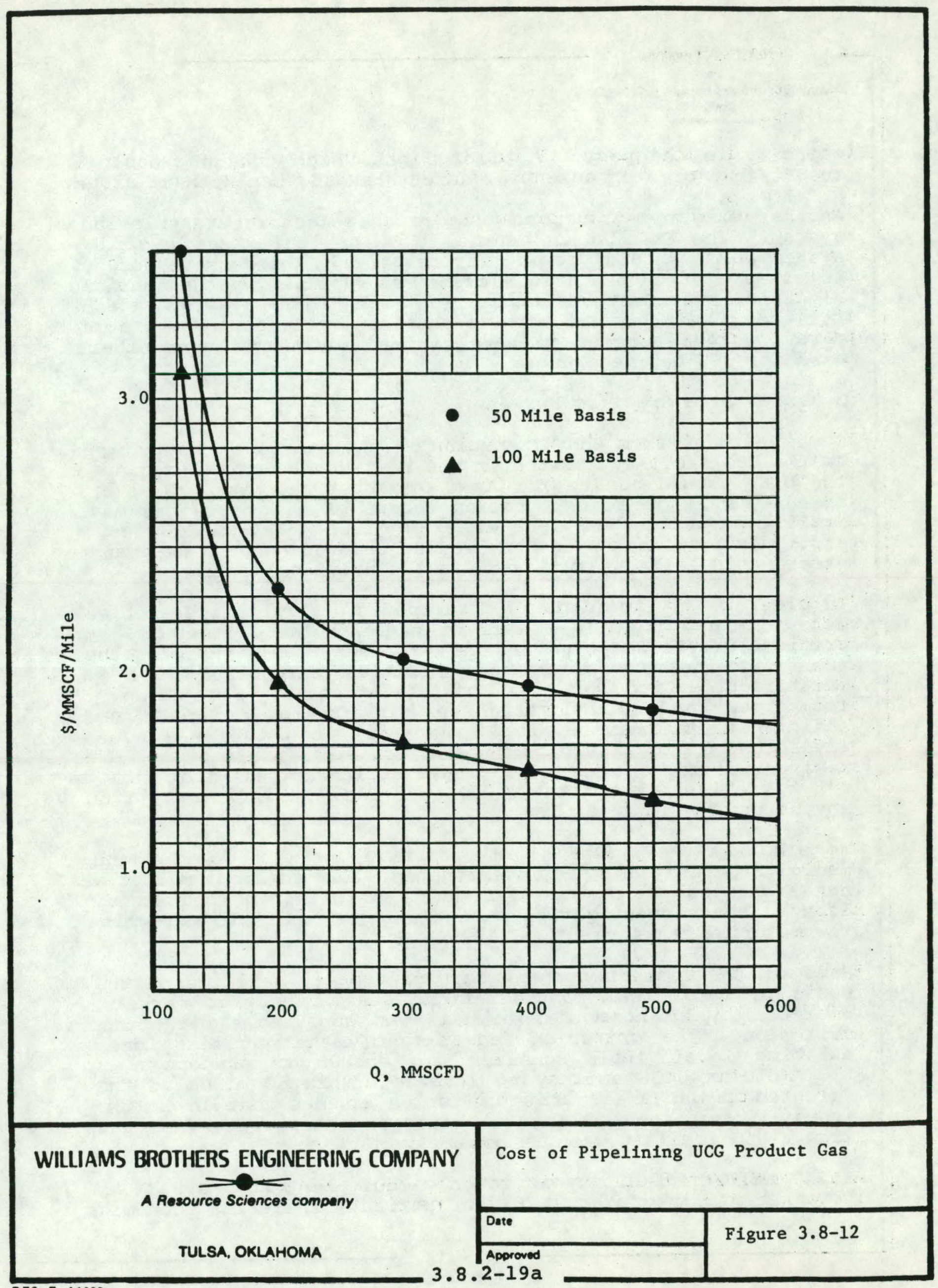


capacity in the past. A pilot light which goes out could result in a greater potential safety hazard than methane alone.

Another existing transport mode is the electric transmission system. The East North Central U.S. has an extensive grid system which should provide for relatively inexpensive access. An example of such a grid network was supplied by the American Electric Power Service Corporation, see Figure 3.8-13. Again, the use of modular gas turbine combined cycle or co-generation power systems appears to have certain advantages over other uses for UCG derived gases.

\subsubsection{Site Specific Markets}

It is evident from the discussion in the previous sub-sections that a UCG facility located in the East-North-Central region of the U.S. should not be far from an industrial base. However, the low economic transportation radius of a low BTU gas may limit distribution to less than 50 miles. Medium BTU gas, particularly with the carbon dioxide removed, should be able to exceed this limit as indicated in the previous section.

In order to try to identify site specific markets a search was made within a 50 mile radius of each of the fifteen (15) originally defined potential target areas. Only existing fuel users in the industrial and utilities categories were identified. Site specific possibilities of attracting industries into an industrial park complex or the need for additional intermediate load power in the future was not investigated and should be the subject of a future study. The residential market was not reviewed as it was felt that this is not a viable market although it will benefit indirectly from any natural gas tradeoff.

To simplify the analysis only potential markets for low and medium BTU fuel gas were investigated. The chemical market was not addressed due to the difficulty of obtaining meaningful data without investigating each plant in detail to determine raw material requirement.

Each of the fifteen target areas previously selected on the basis of geological considerations was tested for market potential by using available data and applying a marketing criterion. The criterion requires only that at least one existing fossil fuel consumer big enough to support a $230 \mathrm{MMBTU} / \mathrm{hr}$ UCG facility be located within 50 miles of the selected target area. This criterion assumes that an existing industry would be willing to switch or incorporate fuel gas from a UCG facility when it became available.

A $230 \mathrm{MMBTU} / \mathrm{hr}$ facility is roughly equivalent to a $3.5 \mathrm{MM}$ ton resource utilized over a 20 year period. While the economics 


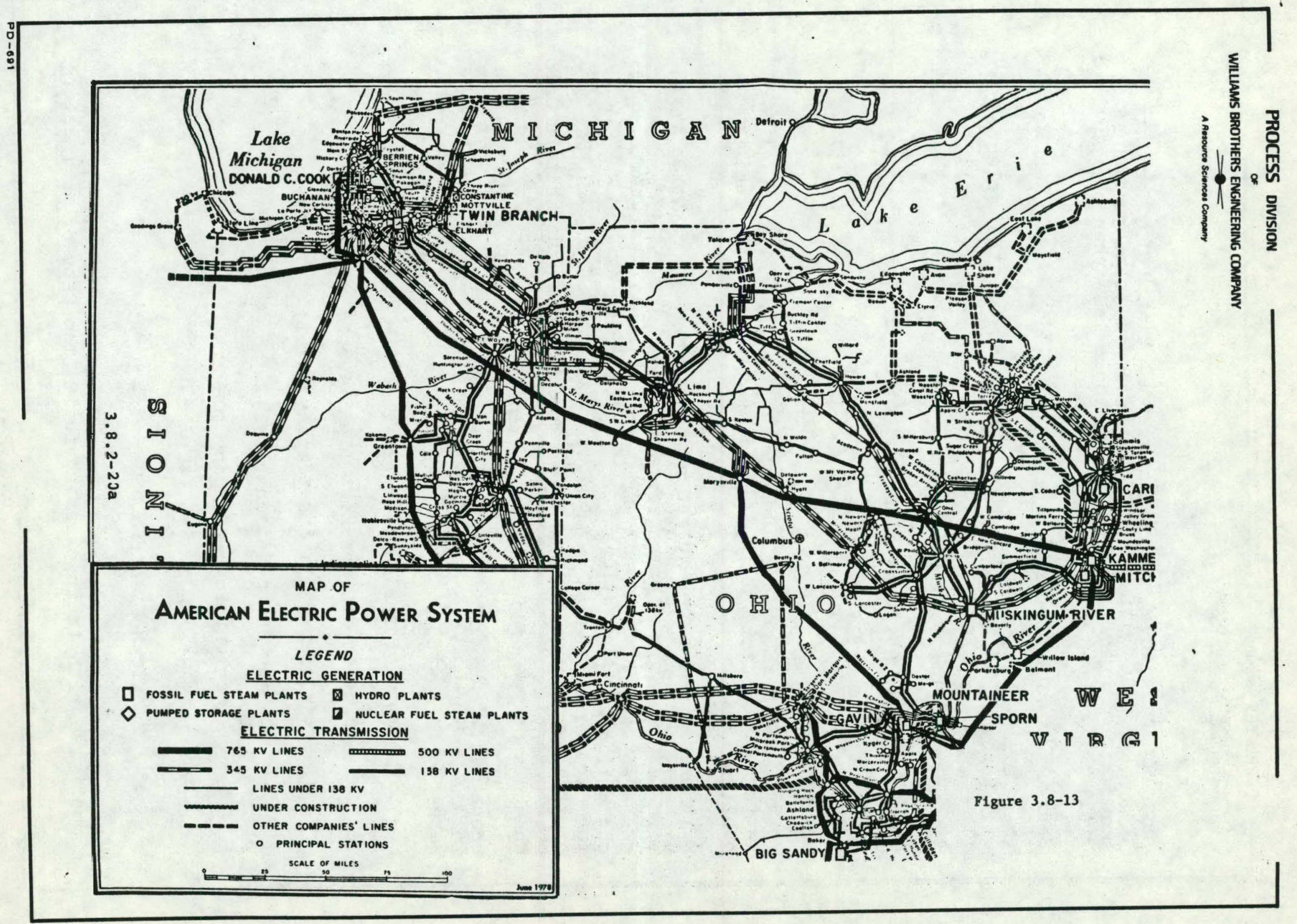




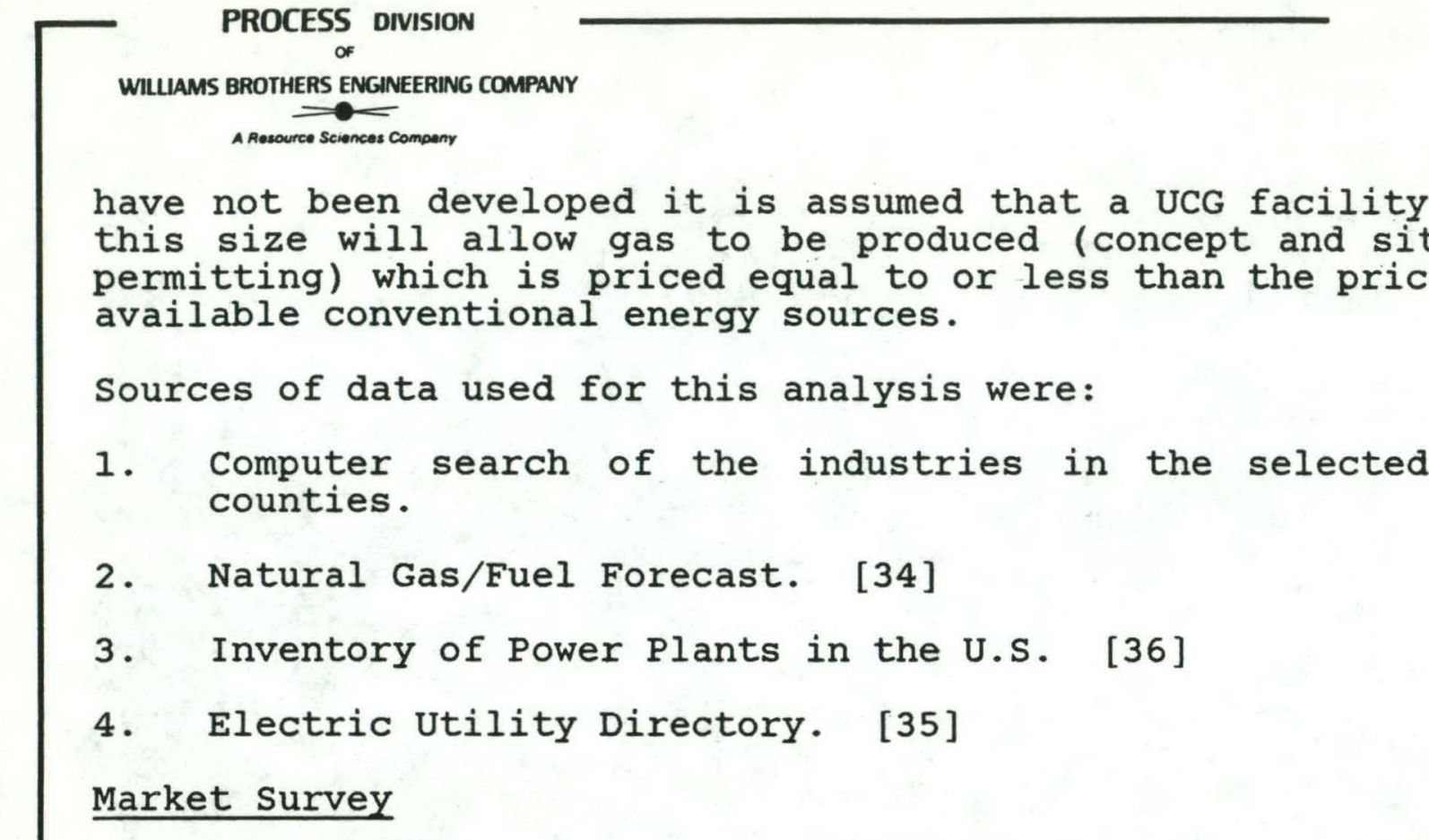

Market information was obtained by phone calls, inquiry letters, computer searches and government and regional publications.

Written inquiries were directed to chambers of commerce in the vicinity of the target areas to ascertain interest. This inquiry met with very limited success. Only two chambers of Commerce indicated enthusiasm in their response. Out of twelve chambers to which letters were sent, only four replied. The form letter mailed and addresses used are attached to the end of this section as well as the responses from the Eastern Ohio Development Council, and the Greenville and Central City Chambers of Commerce, see Attachment I.

Phone calls were placed to several power utilities with units in the vicinity of the target areas. Among these utilities were the following:

\begin{tabular}{|c|c|}
\hline 0 & City of springfield (IL-2) \\
\hline o & City of McCleansboro $(\mathrm{IL}-3,4,5,6)$ \\
\hline ० & Kentucky Utilities Company (KY-1) \\
\hline o & Commonwealth Edison (IL-2) \\
\hline ० & Allegheny Power Company $(\mathrm{OH}-2,3)$ \\
\hline ० & Illinois Power $(\mathrm{IL}-1)$ \\
\hline o & American Electric Power $(\mathrm{OH}-1,2,3)$ \\
\hline
\end{tabular}

Most replied that they would be interested, if the price was competitive with their existing fuel. The city of springfield 
is interested because much of their generating capacity will need replacing in the early $1990^{\prime} \mathrm{s}$. Kentucky Utilities has already assessed using a low or medium BTU gas from coal gasifiers (surface). The transportation costs made it more expensive than coal bought at \$23-32/ton delivered. As a means of allowing higher sulfur coals to be burned the study suggested that a low BTU gas would present reliability problems. Commonwealth Edison may be interested if the price is competitive with \#6 oil which is currently used in their peaking units. However, these units only have an operating factor of about $30 \%$. In addition, there would have to be sufficient price differential to justify breaking an existing $20 \mathrm{yr}$. oil contract. Illinois Power is currently evaluating the use of the Allis-Chalmers Kilngas coal gasification process. They are sharing an investment of $\$ 5.5$ million for the construction and demonstration phases of this process. The objectives of the program include demonstrating the feasibility of power generation with environmentally acceptable low BTU gas derived from Illinois coal. They have reviewed UcG technology with Texas Utilities, the licensor for soviet UCG technology in the United states.

\section{Fuel Gas Consumers}

The counties in which a majority of the land area falls within the 50 mile radius of the target area are listed in Table 3.8-10. These counties were used as the basis for a search for current natural gas users.

Attachment 2 is a compilation of most major industrial natural gas consumers in the counties identified. other data given in Attachment 2 includes: names of suppliers, volume of natural gas delivered in 1978, and potential substitute fuels.

The $230 \mathrm{MMBTU} / \mathrm{hr}$ required to justify a target area is approximately equivalent to 2 billion cu. $\mathrm{ft} . / \mathrm{yr}$. On the entire list there are only 11 industrial consumers out of the 147 listed that meet this minimum requirement for a potential market. These 11 potential markets are listed separately on Table 3.8-11.

\section{Power Plants}

The search for existing power plants was limited to counties at least a portion of which fell within an arbitrary 50-mile radius around each site. These counties are identified in Table 3.8-10. All of the power plants identified are listed on Attachment 3. As indicated in Table 3.8-12, there are sixteen power plants above the $25 \mathrm{MW}$ criterion (approximately equivalent to $230 \mathrm{MMBTU} / \mathrm{hr}$ assuming an efficiency of $37 \%$ ). Power plants located within ten miles of a site were considered 
TABLE 3.8-10

GMINTIES HITHIN A 50 mILE RADIUS of

IDEMTIFIEU TARIIET AREAS

\begin{tabular}{|c|c|c|c|c|c|}
\hline \multicolumn{4}{|c|}{ WEST VIRCINIA } & \multicolumn{2}{|c|}{ outn } \\
\hline Couney & Sttes & County & Sttes & County & stices \\
\hline Roane* & $w V-1,3,4$ & Harrison & W-4 & Moaroe & $04-1,2,3 *$ \\
\hline Calloun * & $w V-1,3,4$ & Kandolph & WV-4 & Belmont & $\mathrm{OH}-1,2,3=$ \\
\hline Wirt & $1 . V-1.3$ & Kucahontas & $W V-4$ & Guernsey & $\mathrm{OH}-1.2 .3$ \\
\hline Jackion & $W V-1,3$ & Greenbriar & WV-4 & Musk Ingue & $\mathrm{OH}-1,2,3$ \\
\hline Mason & $w N-1,3$ & Cabell & $w v-2$ & Morgan & $\mathrm{OH}-1,2,3 *$ \\
\hline Putnan & $w V-1,2,3$ & Wayne* & $\mathbf{w}-2$ & Washington & $011-1,2,3$ * \\
\hline Kanawha* & WV $-1,2,3$ & Lincoln* & WV-2 & Noble & $\mathrm{OH}-1,2,3 *$ \\
\hline Clay* & $w v-1,3,4$ & Logan $\star$ & $w-2$ & Harrison & $04-1$ \\
\hline Fayete & $W V-1,3,4$ & MIngo & $w-2$ & Perry & $\mathrm{OH}-2,3$ \\
\hline Micholay * & $w v-1,3,4$ & Wyow Ing & WV-2 & Athens & $0 \mathrm{H}-2,3$ \\
\hline Webster * & $w v-1,3,4$ & Pleasancs & $\mathrm{OH}-1,2,3$ & Meig* & $O H-2,3$ \\
\hline Brexton & $w v-1,3,4$ & Tyler & $\mathrm{OH}-1,2,3$ & & \\
\hline C1Imer * & $w v-1,3,4$ & Nerzel * & $04,1,2,3$ & & \\
\hline artechie & $W V-1,3,4$ & Marslial* & $04-1,2,3$ & & \\
\hline Boune & $w-1,2,3$ & McDowell * & $K Y-2$ & & \\
\hline Hood & $W V-1,3$ & & & & \\
\hline Levio & $w-1,3,4$ & & i & . & \\
\hline Daddr Idge & $\mathbf{U N}-3,4$ & & & $!$ & \\
\hline Upahír & $w-3.4$ & & $:$ & $\vdots$ & \\
\hline
\end{tabular}

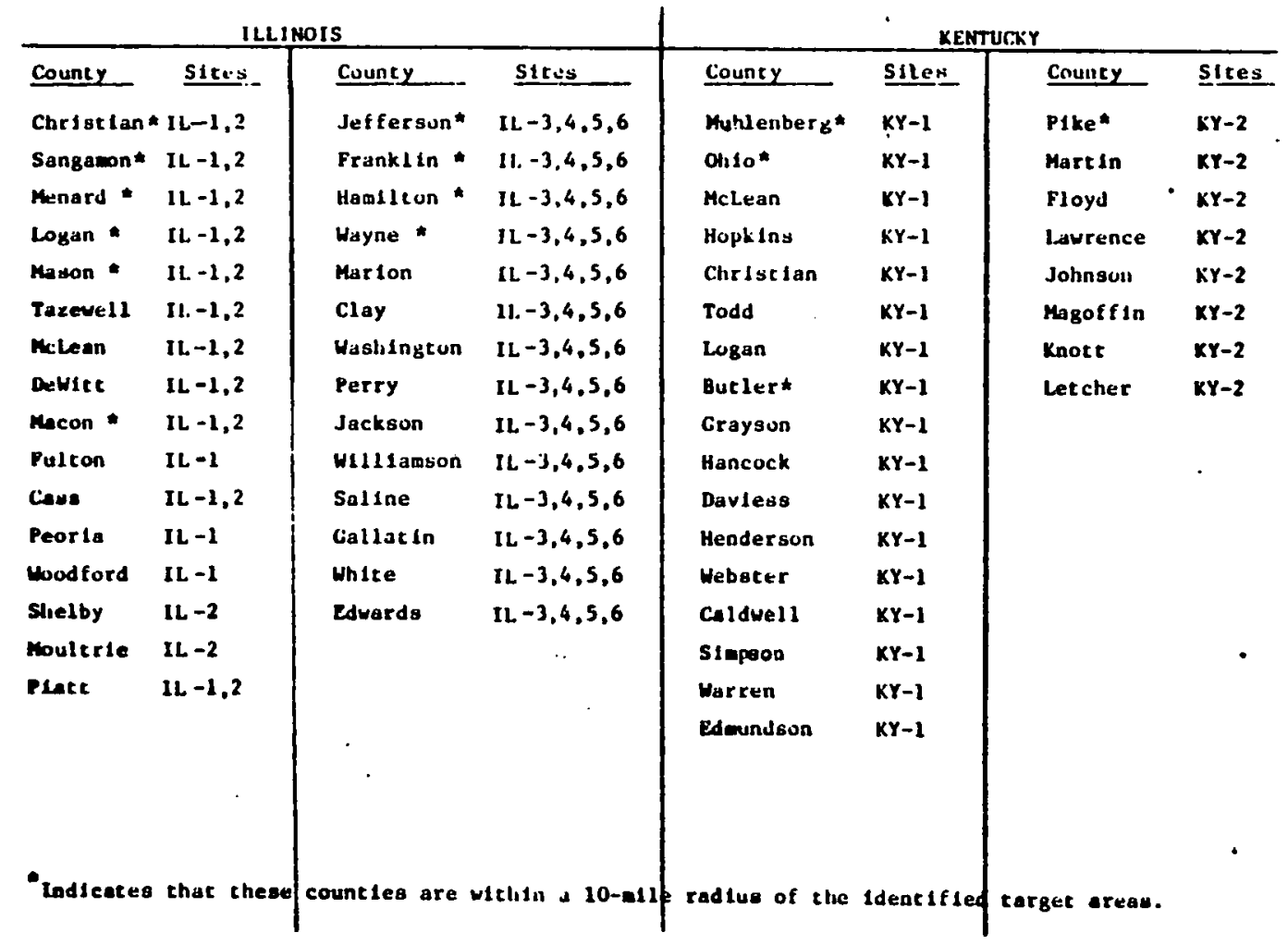




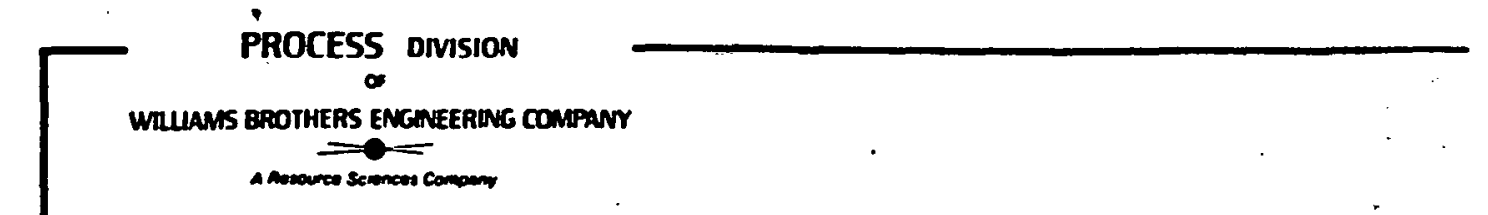

TABLE $3.8-11$

SUMMARY OF EXISTING INDUSTRIAL CONSUMERS

THAT MEET MINIMUM REQUIREMENT*

\begin{tabular}{|c|c|c|}
\hline Site(s) & Company & Quantity \\
\hline IL-2 & Keystone Steel \& WIre & $2,443,000$ \\
\hline IL-2 & Nat. Distillers \& Chem. Corp. & $15,268,032$ \\
\hline $\mathrm{IL}-1,2$ & A.E. Staley & $7,416,777$ \\
\hline IL-1,2 & Archer Daniels Midland-West & $2,478,228$ \\
\hline $\mathrm{IL}-1,2$ & Hopper Paper Co. & $6,691,538$ \\
\hline $\mathrm{KY}-1$ & Martin Marietta Aluminum Co. & $2 ; 246,096$ \\
\hline $\mathrm{OH}-1,2,3$ & Anchor Hocking Corp. & $2,105,000$ \\
\hline $\mathrm{OH}-1,2,3$ & Consolidated Aluminum Corp. & $4,048,157$ \\
\hline WV $-1,2,3,4$ & Du Pont & $3,035,769$ \\
\hline$W V-1,2,3,4$ & Du Pont & $13,931,348$ \\
\hline$w V=1,2,3,4$ & L1bbey Owens Ford & $2,341,000$ \\
\hline
\end{tabular}


PROCESS DIVISION

WIULAMS BROTHERS ENGINEERING COMPANY

$=$

A Resounce Scioncos comeany

TABLE $3 \cdot 8-12$

POWER PLANT LOCATION RELATIVE TO SITES

\section{ILLINOIS}

A. Havana Unit

$35 \mathrm{mi}$ from $\mathrm{I}-1$

B. Kincaid Unit

$25 \mathrm{mi}$ from $\mathrm{I}-2$

C. Dallman Units, Factory Units

Lakeside Units, \& Reynolds Unit

$18 \mathrm{mi}$ from $\mathrm{I}-2$

\section{KENTUCKY}

A. Green River Unit

$12 \mathrm{mi}$ from $\mathrm{K}-1$

OHIO

A. Berger R.E. Units

$23 \mathrm{mi}$ from $0-1$

B. Krammer Units

$23 \mathrm{mi}$ from $0-1$

c. Mitchell Units

$21 \mathrm{mi}$ from $0-1$

D. Willow Island and Pleasants Units

$10 \mathrm{mi}$ from $0-2$

E. Muskingum River Units

$9 \mathrm{mi}$ from $0-3$

WEST VIRGINIA

A. John E. Amos Units

$32 \mathrm{mi}$ from $\mathrm{WV}-1$

B. Cabin Creek Units

$23 \mathrm{mi}$ from $\mathrm{WV}-1$

C. Kanawha River Units

$20 \mathrm{mi}$ from $\mathrm{WV}-1$ 


\section{$[$ maxsy and}

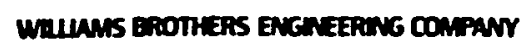

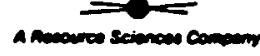

primary targets. Only. three of these power plants are actually located within a ten mile radius of any of the target areas.

The locations of each of the power plants which meet the minimum marketing criterion relative to location of the target areas are listed in Table 3.8-12 and are illustrated in Figures $3.8-14,15,16$ and 17 .

One utility has stated that it is involved in a current project to utilize low-BTU gas. It may be possible to work out an arrangement for a power company to purchase the coal field out-right and aid them in developing the field by placing a UCG gas burning plant on-site. As discussed earlier, combined-cycle or co-generation gas turbines have advantages in this application:

\section{Chemicals}

Current consumers of synthesis gas, methanol, tars/oils, and chemicals were investigated using a computer search of industrial listings and resource literature from chambers of commerce. A search was made only in the counties where the potential sites were located. The result was inconclusive.

\subsubsection{Evaluation}

As indicated in Table 3.8-13 there are several existing energy consumers near the identified target areas.

Power plants, even though currently consumers of coal, oil, and natural gas are targets for early conversion to MBG. Many indivdual power plants as indicated in Attachment 3 are of sufficient size to handle the entire output of a $230 \mathrm{MMBTU} / \mathrm{hr}$ facility. Due to the high cost of transporting LBG and the necessity to derate a boiler significantly the use of MBG is recoimmended.

There are three previously identified target areas which have power plants near them: $K Y-1 ; \mathrm{OH}-2 ;$ and $\mathrm{OH}-3$. The $K Y-1$ target area is in Muhlenberg County, the Chamber of Commerce of which responded to a written inquiry in an extremely positive manner. The $\mathrm{OH}-2$ and 3 areas may require that a pipeline cross the Muskingum River and/or the ohio River, see Figure 3.8-18. It may be that the cost of crossing a river, particularly one as large as the ohio River, would justify an alternate longer route.

Other target areas which have both industry and power plants within a 50 mile radius are as follows: IL-1, IL-2, OH-1 and $W V-1$, and $W V-3$ 


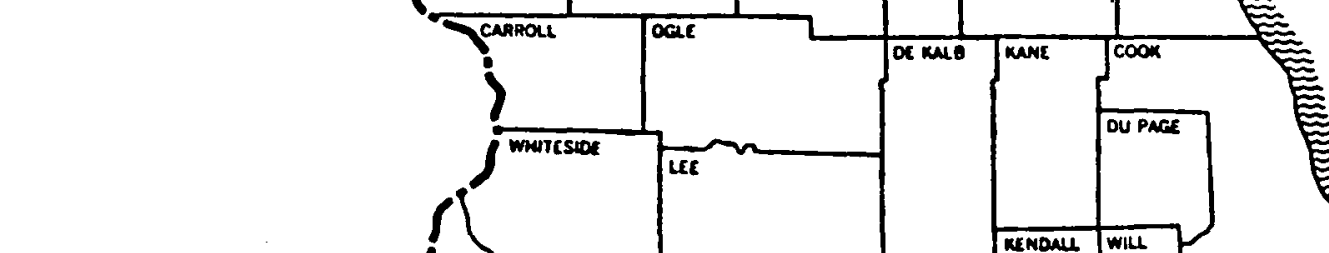

CLEARTYPE COUNTY OUTLINE

ILLINOIS

Bate of mikes

- $10 . . .90$

MAP NO. แ1

Mren mom

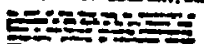

Figure 3.8-14

Power Plant Location

C) American Map Co., Inc., New York. Permit No. 18604

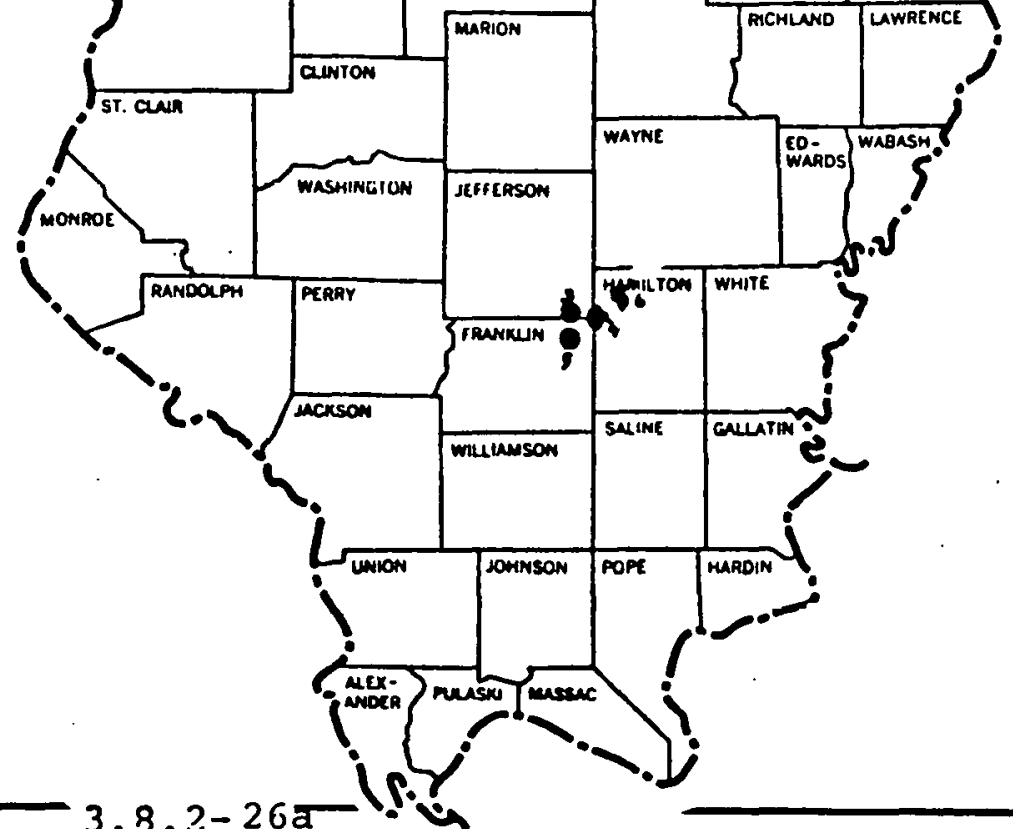




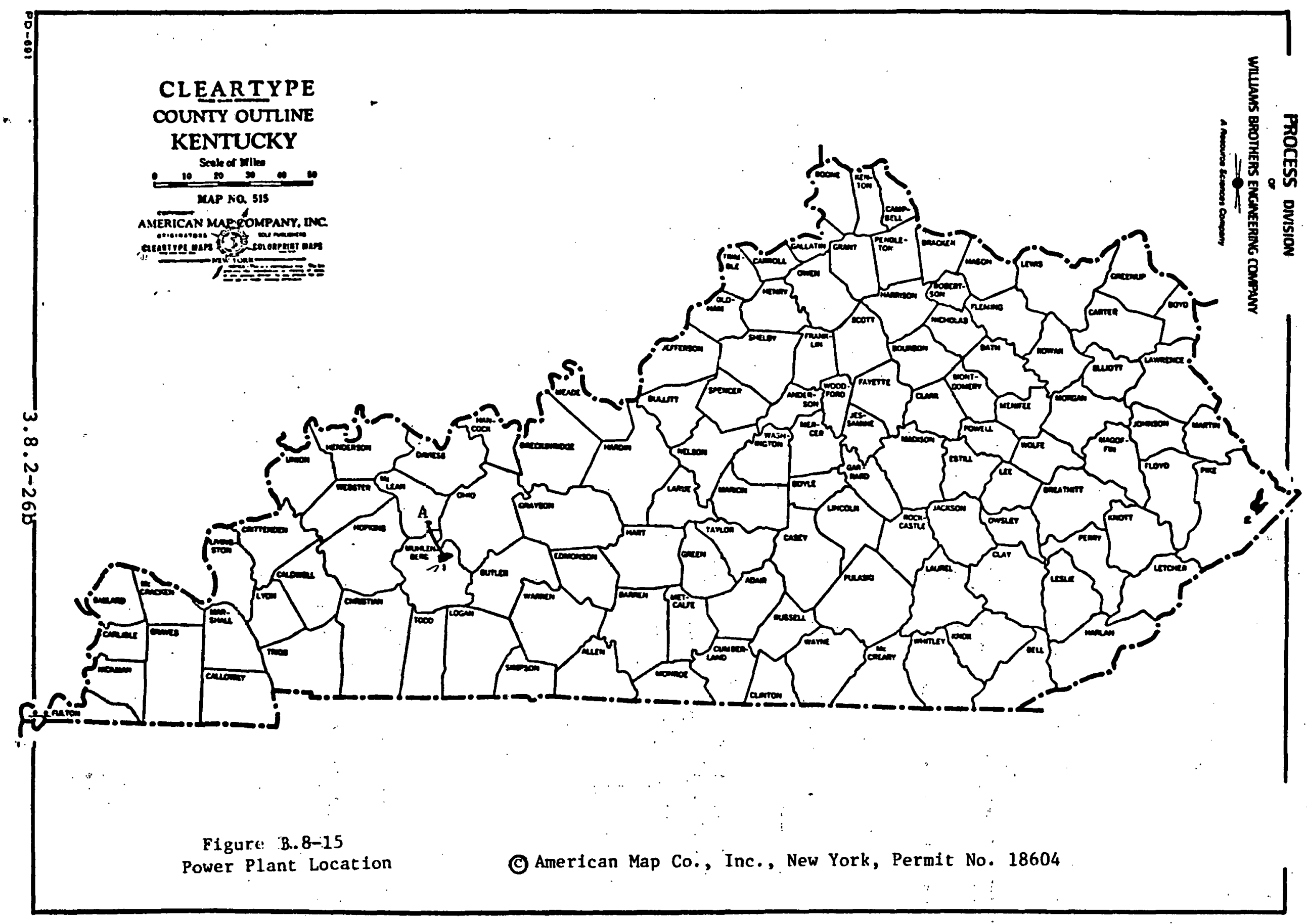




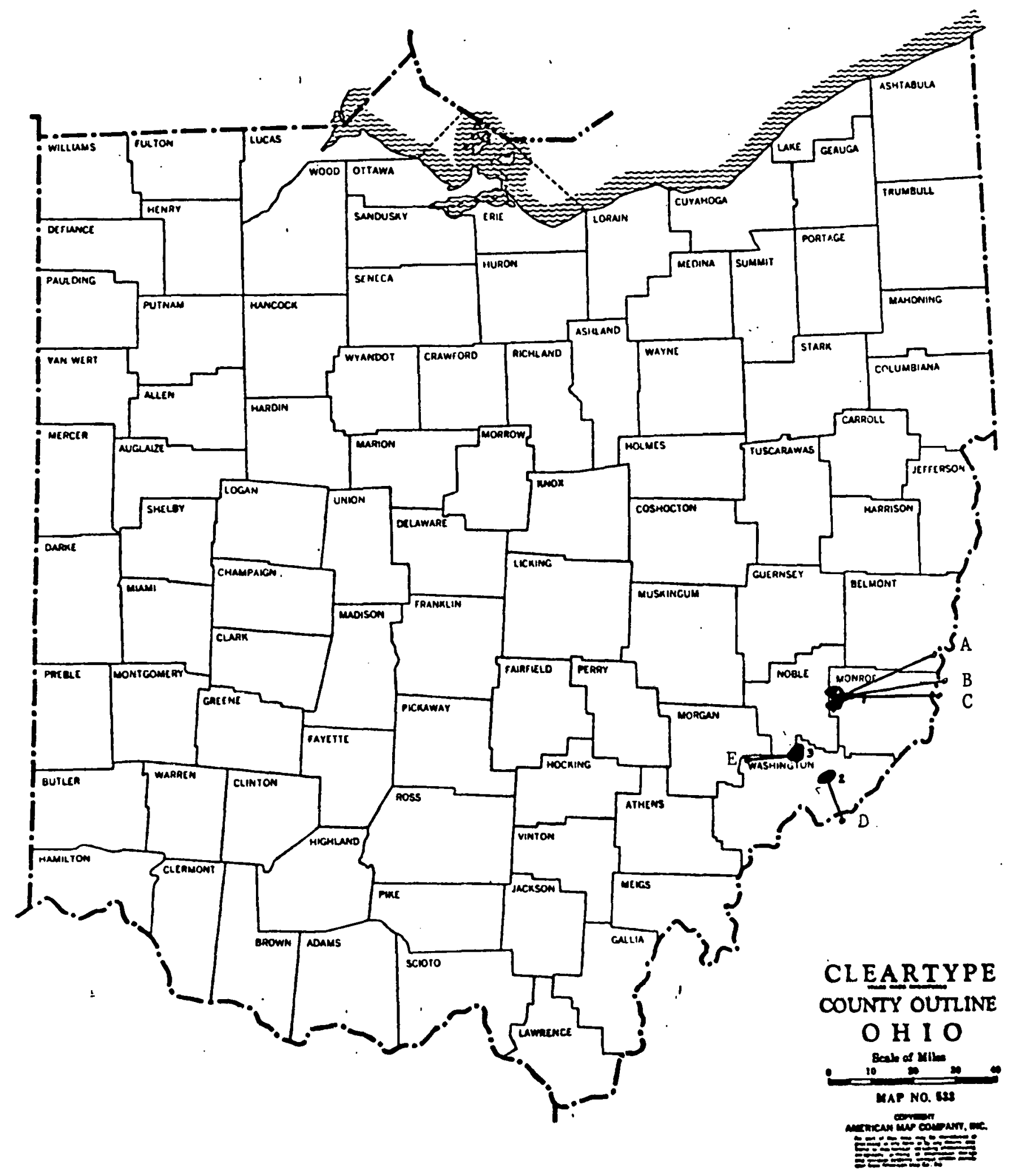

(1) American Map Co., Inc., New York, Permit No. 18604

WILLIAMS BROTHERS ENGINEERING COMPANY

A Resource Scionces compeny

TULSA, OKLAHOMA
Power Plant location 


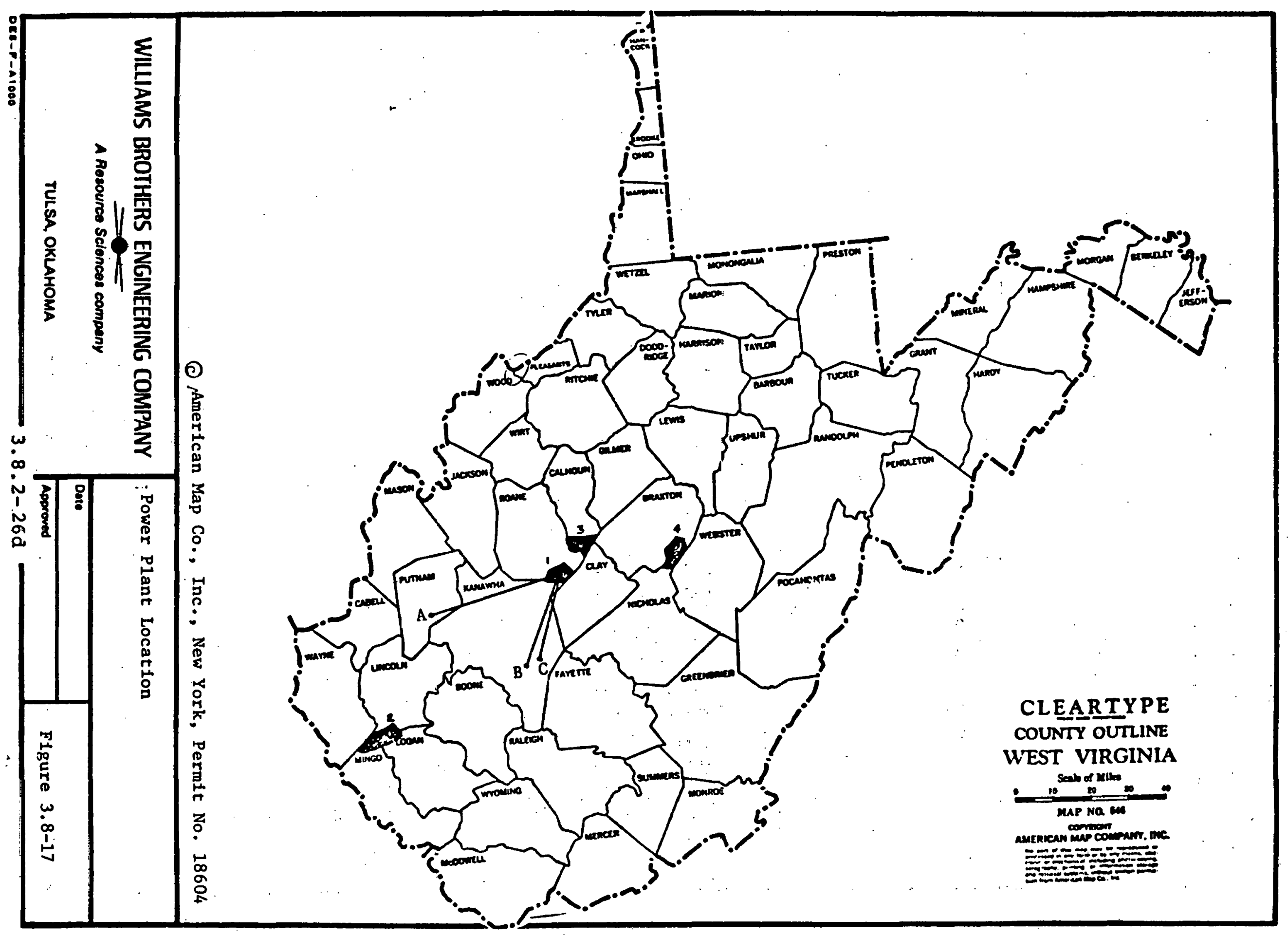




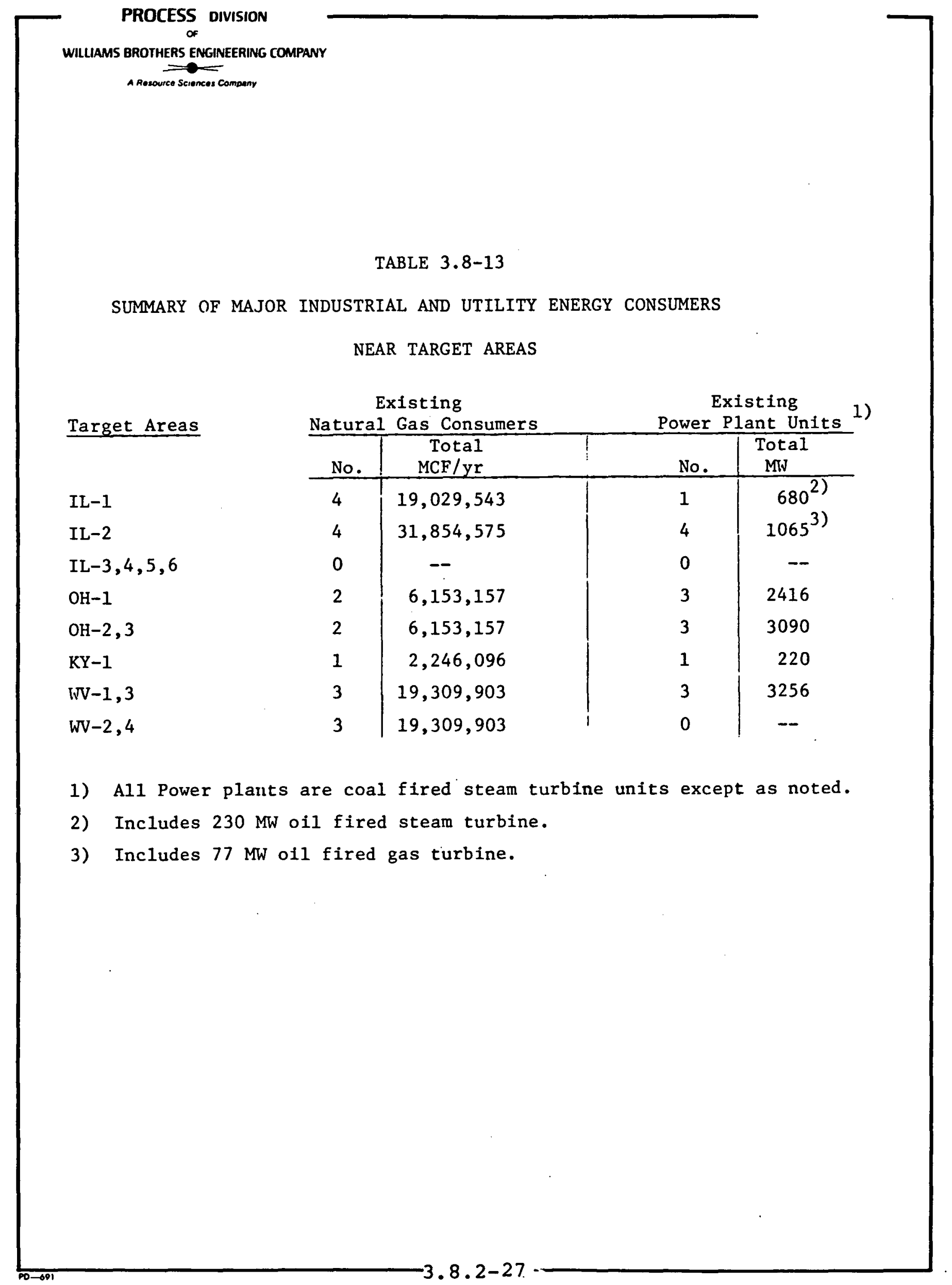




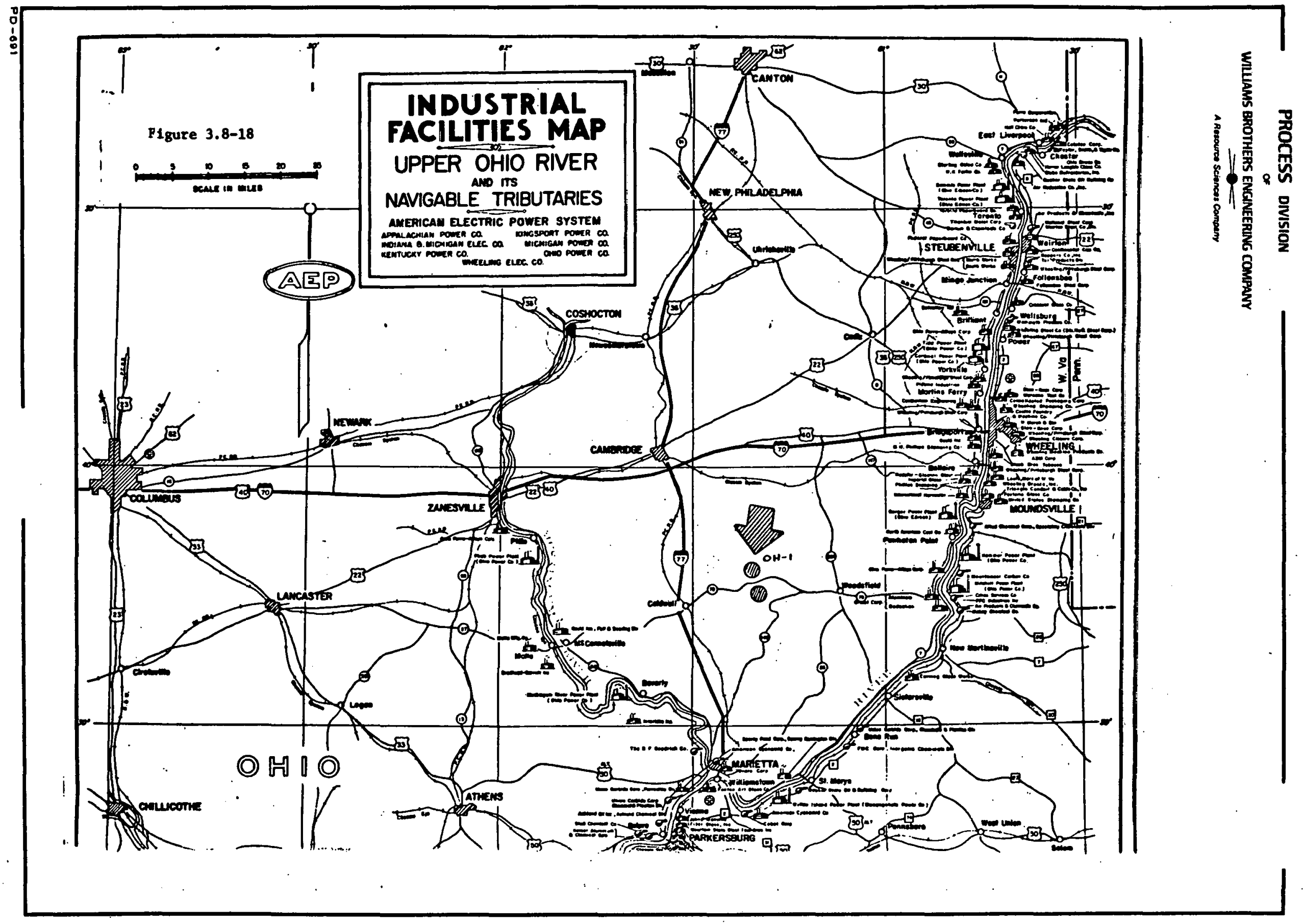


PROCESS DIVISION

WILLIAMS BROTHERS ENGINEERING COMPANY

A Resource Sciences Compony

Price, reliability of supply and compatibility with existing equipment will be key ingredients to getting acceptance by the utility sector.

Sites such as IL-3, 4, 5 and 6 which are not in industrial areas will either need to produce transportable fuels such as SNG or methanol, or at least high grade MBG into a $350+$ BTU/SCF product by carbon dioxide removal. Industrial complexes such as St. Louis are within a 100 mile radius.

$3.8 \cdot 2-28$

4389-036 
REFERENCE LIST

SECTION 3.8 .2

1. U.S. Dept. of Energy Report, "Reducing U.S. Oil

Vulnerability-Energy Policy for the 1980's", DOE/PE-0021, November 10,1980 .

2. R. F. Sullivan, D. J. O'Rear, H. A. Framkin,

B. E. Stangeland, "Refining of Syncrudes", Chevron Research Co., Dept. of Energy Sponsorship.

3. L. Winsor, "Technical Considerations in Switching to Gas Derived from Coal in Utility Boilers", Presented at Symposium on Advances in Coal Utilkization Technology IV, April 20-24, 1981, Denver, CO.

4. M. T. Eckhart, "The Market for Gas from Coal", Energy Engineering, June/July, 1981.

5. A.G.A., "Reserves of Crude Oil, Natural Gas Liquids, and Natural Gas in the United states and. Canada as of December 31, 1979", Vol. 34, June 1980.

6. DOE, "U.S. Crude Oil and Natural Gas Reserves, 1977 Annual Report", DOE/EIA-0216(77), February 1980; : 1978 Annual Report, DOE/EIA-0216178), September 1980. Based on data from Form EIA-23, "Annual survey of Domestic Oil and Gas Reserves." "Principal. Findings of the 1979 U.S. Crude Oil, Natural Gas, and Natural Gas Liquids Report", DOE/EIA-0216(79)EX, April 1981. Natural gas liquids reserves begin with the 1979 reserves report.

7. DOE, Monthly Energy Review, May 1981.

8. DOE, Energy Information Administration Annual Report to Congress 1980, Vol. 2, DOE/EIA-0173(80)/2.

9. DOE, Energy Data Report, Annual Energy Balance, 1979 (issued June 1980).

10. Subhash Bhagwat, "Future Competitive Position of Illinois Basin Coal."

11 G. E. Weismantel, "Methanol Supplies: Too Much or Too Little?", Chemical Engineering, July 14, 1980, pg. 75-78.

12. National Petroleum News, Mid-June 1981.

13. Chemical Engineering, November 16, 1981, pg. 39. 


\section{5 morars anama}

WILUAMS BROTHERS ENGINEERING COMPANY

A Resource Seionces compeny

14. DHR, Inc., Synfuels Week, september 28, 1981.

15. D. Sperling, Synfuels Week, September 21, 1981.

16. W. C. Ulrich, M. S. Edwards, R. Salmon, "Evaluation of an In Situ Coal Gasification Facility for Producing M-Gasoline Via Methanol", ORNL-5439, December 1979.

17. Pritchard Corporation, "Evaluation of the Use of UCG Gas to Produce 4,000 BPD and 12,000 BPD of Methanol with Conversion to M-Gasoline", Dept. of Energy Study Under Contract No. DE-ACO1-80ET14372.

18. A. J. Moll, "Economic Comparison of UCG with Surface Coal Gasification Processes", Paper presented at 6th UCC Symposium, July 13-17, 1980, Afton, Oklahoma.

19. A. P. Sikri, "Economic Evaluation of Underground Coal Gasification", Paper presented at 5th UCC Symposium, June 18-21, 1979, Alexandria, Virginia.

20. J. H. Marten, "Methanol Plant", Testimony to the United States House of Representatives subcommittee on Power and Energy, Washingtion, D.C., December 18, 1980.

21. EPRI Report, "Coal to Methanol", EPRI AP-1962.

22. Badger Plants, Inc., Dept. of Energy sponsored study, FE-2416-24.

23. Peat Methanol Assoc., Synfuels Week, September 21, 1981.

24. J. K. Paul, ed., "Methanol Technology and Application in Motor Fuels", Nayes Data Corp., 1978.

25. Energy Topics, August 3, 1981.

26. J. E. Boysen, R. D. Gunn, D. L. Whitman, "An Economic Sensitivity Study of UCG Based on Field Performance, Theory, and Operational Experience", Presented at 4th UCC in Steamboat Springs, Colorado, July 1978.

27. D. L. Biblack, "The Economics of Four Options to Utilize Underground Gasification of Kaiparowits Coal to Generate Electricity", Presented at 4th UCC in steamboat Springs, Colorado, July 1978.

28. A. P. Sikri, "Economic Evaluation of Underground Coal Gasification", Paper presented at 5th UCC Symposium, June 18-21, 1979, Alexandria, Virginia. 


\section{$\Gamma$ morss}

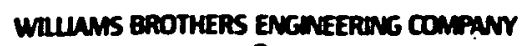

A Anecoures seimices compeny

29. J. R. Mann, "The Economics of Underground coal Gasification in British Conditions", Presented at the 3rd UCC Symposium, June, 1977.

30. D. P. Bogt, et al, "Energy Availabilities for state and , Local Development Projected Energy Patterns for 1985 and 1990", Report Sponsored by U.S. Dept. of Commerce, ORNL/TM-5890/S5, November 1979.

31. U.S. Dept. of Energy, "Sulfur Content in Coal shipments", DOE/EIA-0263 (78), June 1981.

32. U.S. Dept. of Energy, "Cost and Quality of Fuels for Electric Utility Plants. - December 1980", DOE/EIA-0075 (80/12.

33. Chemical Week, November 1981, pg. 41.

34. Natural Gas/Fuel Forecast - 1977-78 Series B/ Industrial. McGraw - Hill Publication.

35. Electrical World Directory of Electric Utilities. 89th ed. New York: McGraw - Hill, 1980 .

36. Inventory of Power Plants in the United States April 1979. McGraw - Hill Publication. 


\subsubsection{Conclusions}

The following conclusions were drawn from the preceding study.

1. The U.S. will continue to require new sources of energy fuels and substitutes for petrochemical feedstocks into the foreseeable future. Most of this requirement will be met using coal. However, the cost of mining, transporting, cleaning, and preparing coal, disposing of ash or slag and scrubbing stack gases continues to rise; particularly, in the Eastern U.S. where the need is greatest. UCG avoids these pitfalls and, as such, should be considered a viable alternative to the mining of deeper coals.

2. Of the two possible product gases LBG and MBG, MBG is the most versatile. (I.t may actually be the least expensive option for projects of sufficient scale.)

3. The most logical use for UCG product in the Eastern U.S. is to generate power on-site using a combined-cycle or co-generation system. Either low or medium BTU gas (LBG or MBG) can be used. PURPA will provide incentive for industrial firms to install the co-generation facilities.

4. UCG should be an option whenever surface gasification is considered; particularly, in areas where deeper, higher sulfur coal is located.

5. There are environmental and social benefits to use of UCG over surface gasification in the Eastern U.S.

6. The East-North-Central Census Region is the most logical section of the country to site an alternate fuels project based on underground gasification of bituminous coal. Potentially amenable coal resources, high prices for fuel oil and natural gas, and a large imported energy flow form the basis for this conclusion.

7. A site could be chosen almost anywhere in the IIlinois and Ohio area where amenable UCG coal has been determined due to the existance of existing transportation or transmission systems. The potential radius of up to 150 miles for an upgraded MBG gas using a new pipeline would put Columbus and Pittsburgh in range of $\mathrm{OH}-1$ and St. Louis within range of IL-4, 5, and 6 . However, the closer a site could be located to its intended market, the better the chances for economic parity with competitive fuels.

8. The technology needs to be demonstrated and the potential economic viability determined at a site in the 
WRUAS BRonteRs ENTSEERTNG COMPANY $\Longrightarrow$

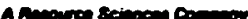

East-North-Central U.S. which has commercial quantities of amenable bituminous coal before utilities will show significant interest. To bring about timely adoption of the technology, state or federal government will need to sponsor the basic research and initial field testing.

9. While methanol has excellent potential as a marketable product. which can be produced from UCG product gas, the economies of scale required to produce it at a competitive price may dictate production in the western states using thicker sub-bituminous coals. 


\section{-PROCESS DIVISION}

$\infty$

WILLIAMS BROTHERS

ENGINEERING COMPANY

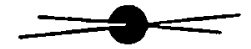

A Rosouice Scennces Compeny
RESOURCE SCIENCES CENTER |6600 S. YALE AVE. | TULSA. OKLAHOMA 74177

PHONE (918) 496-5020| TELEX $49-7493$ WBEC-TUL

January 13,1981

Addresses of Chambers of Commerce 1isted in Attachment Ia(2)

Re: Contract DE-AC05-80MC14584

Assessment of UCG in Bituminous Coals

Gent lemen :

Williams Brothers Engineering Company is currently working on a contract for the Department of Energy to evaluate underground coal gasification technology in bituminous coals. One of our contract tasks is to locate sites in the 48 lower continguous states which appear suitable for this technology. We are pleased to inform you that as a result of an initial geological screening, a potential site has been identified in your area.

Tn ariler for a sile to he commurelally viallle, a ninimun number of criteria must be met. These criteria involve: resource, land availability/ accossibility, political climate, envirunmental considerations, indigencus workforce, and market potential. To date, all we have is an indication that a resource meeting certain geological/technical criteria is present in your vicinity and that there is a likelihood that other criteria can be met.

Williams Brothers is hereby requesting information on your city, county and region, particularly with regard to industries which could use a source of fuel or chemical feedstock. Fuels and feedstocks which could easily be provided from an underground coal gastfiçation facllity include: low heating value gas $(70-170 \mathrm{BTU} / \mathrm{SCF})$ and medium heating value gas (270 $.400 \mathrm{BTU} / \mathrm{SCF}$ ). By further upgrading, synthetic natural gas (SNG), methanol, and gasoline can be produced. Certain byproducts, such as, ammonia and sulfur might also be available in 11 mited quantity. Chemical plants (including pulp and paper, steel mills, metallurgical, petrochemical, etc.), oll refineries, power plants, and large factories are typical types of consumers we need to know about.

In short, we belleve that underground coal gasification might benefit the nation and your region in particular by providing productive employment, a local source of energy, and a new tax base. 
Our timing is such that for your input to be incorporated into our report, it.will be necessary for you to respond to this inquiry by February 7, 1981.

Please submit names, addresses and phone numbers of responsible people in local industry, whenever possible.

Since it is unlikely that people outside of the synthetic fuels industry will. know much about underground coal gasification, a copy of a recent wall Street Journal article is enclosed for your information.

Sincerely,

Process Division

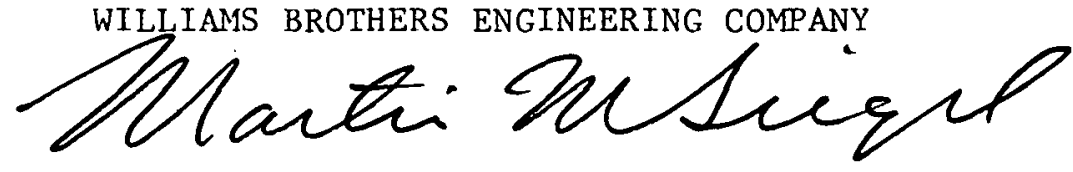

Martin M. Siegel

Manager of Alternate. Fuels Prosessing

Enclosure 
Chambers of Commerce:

Site:

IL-1

$600-1 / 2$ Broadway

P.0. Box 418

Lincoln, IL 62656

217-735-2385

IL-2

102 S. Washington

Mount Pulaski, IL 62548

217-792-5251

and

1 Civic Center Plaza

P.O. Box 1031

Decatur, IL 62525

IL-3 Rt. 15 West \& I-57

P.0. Box 1047

Mount Vernon, IL 62864

IL-4 \& 6 P. . . Box 456

McLeansboro, IL 62859

618-643-3633

IL-5 500 W. Main St.

P.0. Box 574

Benton, IL 62812

618-438-2121

$\mathrm{KY}-1$

P.O. Box 552

Central City, KY 42330

502-754-2360

$\mathrm{KY}-2$

101 Huffman Ave.

P.0. Box 897

Pikeville, KY 41501

606-432-5504

$\mathrm{OH}-1$

120 Hillcrest Dr.

Woodsfield, OH 43793

614-472-5392

OH-2 \& 3310 Front St.

Marietta, Oh 45750

614-373-5176

$W V-1,3$

818 Virginia St. East

\& 4

Charleston, W.Va. 25301

304-345-0770

WV -2
P. O. Box 218

Logan, W.VA 25301

304-752-1324
W. Va. State Chamber of Commerce 1101 Kanawha Valley Building P.O. Box 2789

Charleston, W.Va. 25330 304-342-1115 


\title{
Eastern Ohio Development Council
}

\author{
107 S. Marietta St. \\ St. Clairsville, Ohio 43950
}

February 26, 1981

Mr. Martin M. Siegel

Manager of Alternate Fuels Processing

Williams Brothers Engineering Co.

6600 South Yale Avenue

Tulsa, Oklahoma 74177

Dear Mr. Siegel:

I was very interested to hear of your interest in "in-site" coal gasification. I've long thought it was the ideal method of utilizing some of our deeper seams of coal that can't be mined economically.

To address the problem of market potential, I have included an Industrial Facilities Map of the upper Ohio Valley prepared by American Electric Power about ten years ago. As you can see there are many potential users of a low to medium BTU synthetic natural gas, and I have, in the past six years, developed such users.

The other questions you stated require considerably more work. We can handle the problem of resource through our own Ohio Department of Natural Resources. A considerable amount of new information has been made available in the past year concerming our Ohio coal reserves. For land availability and accessibility I have to know more of your particular requirements. The political and environmental considerations should pose no problem mnless you anticipate an extreme condition. The indigenous work force will have to be evaluated on d site to site bagio ad will the envirnnmental considerations.

Give us some additional guidance on your immediate needs and we will be more than happy to work with you.

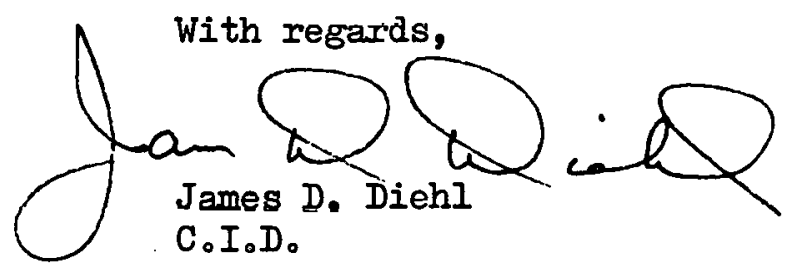

JDD:bo

Enclosure

Copy: Mr. W. B. Moore

Switzerland Chamber of Coumerce

Woodsfield, Ohio 43793 


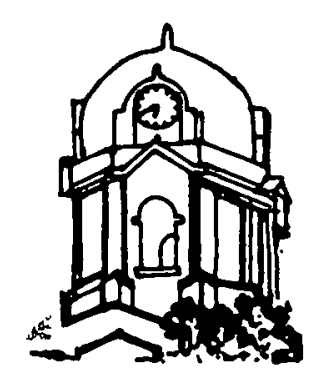

\section{GREENVILLE CHAMBER OF COMMERCE}

\section{P. O. Box $3 / 3$}

Greenville, Kentucky 42345

Phone (502) 338-5422

"Friendly People in a Progressive Town"

February 4, 1981

Williams Brothers Engineering Company

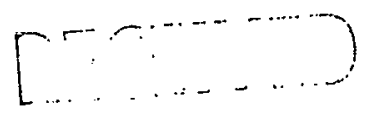

Process Division

Resources Sciences Center

6600 South Yale Avenue

Tulsa, Oklahoma 74177

ATTN: Martin M. Siegel

Dear Mr. Siegel:

The Chambers of Commerce of Greenville and Central City, Kentucky, have met jointly through their Board of Directors to review your interest in our county with regard to a possible site for underground coal gasification. Dur Chambers believe that Muhlenberg County is a prime location for you to consider for this facility. The county has an abundance of coal, land, manpower, transporation facilities, and the time is right to act. Our environmental situation is improving and we believe that we can meet the criteria for you to locate here. We are very much interested.

To give an idea of what is here we enclose a brochure prepared by the State Department of Commerce indicating the type of county we are from an economic standprint. I hope this will be of assistance to you.

There is a local need for new energy in this county. In particular the City of Drakesboro needs fuel to heat the homes of its citizens. There are other industries here which could be heated by this type of fuel.

Kentucky Utilites, Tennessee Valley Authority, and Big Rivers Electric plant are all utility companies in the area which are ootential customers for your fuel to reduce electricity. The headquarters of Tennessee Valley Authority at Knoxville, Tennessee, should be contacted concerning the Paradise Steam Plant located here in Muhlenberg County. James Hunt at the Kentucky Utilities Building, Court Square, Greenville, Kentucky, may be contacted regarding the potential interst of Kentucky Utilities. His phone number is 502-338-3606. In Central City, Kentucky, contact the plant manager at 502-754-4541. The Big Rivers Power Plant is 
William Brothers Engineering Company February 4, 1981

Page 2

still under construction at this time and we are not aware as to the person in charge at this time. I am sure any communication could be directed by letter to Calhoun, Kentucky, and it would get to the proper source.

Locally here, you may contact our County Judge, Honorable Robert Draper, 502-338-2520. You may also contact the Chamber offices directly, Central City being 754-2360, and Greenville being 338-5422. The Chamber President in Central City is Mike Payne and his number is 754-3300. The Chamber President in Greenville is Rev. Charles Midkiff and his office number is 338-3453.

Again we are very much interested in considering your proposal and talking to you. Please contact us if you have any questions and we hope to hear from you soon concerning this matter. If you would like to meet with us feel free to contact us.

Sincerely,

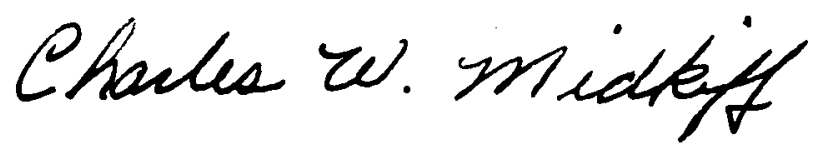

President 


\title{
Central City Chamber of Commexce
}

\author{
CENTRAL CITY, KENTUCKY
}

PRESIDENT

SECRETARY

February 4, 1981

Williams Brothers Engineering Company

Process Division

Resources Sciences Center

6600 South Yale Avenue

Tulsa, Oklahoma 74177

ATTN: Martin M. Siegel

Dear Mr. Éicgel:

The Chambers of Commerce of Greenville and Central City, Kentucky, have met jointly through their Board of Directors to review your interest in our county with regard to a possible site for underground coal gasification. Dur Chambers believe that Muhlenberg County is a prime location for you to consider for this facility. The county has an abundance of coal, land, manpower, transporation facilities, and the time is right to act. Our environmental situation is improving and we believe that we can meet the criteria for you to locate here. We are very much interested.

To give an idea of what is here we enclose a brochure prepared by the State Department of Commerce indicating the type of county we are from an economic standpoint. I hope this will be of assistance to you.

There is a local need for new energy in this county. In particular the City of Drakesboro needs fuel to heat the homes of its citizens. There are other industries here which could be heated by this type of fuel.

Kentucky Utilites, Tennessee Valley Authority, and Big Rivers Electric Plant are all utility companies in the area which are Dotential customers for your fuel to reduce telectricity. The headquarters of Tennessee Valley Authority at Kncxville, Tennessee, should be contacted concerning the Paradise Steam Plant located here in Muhlenberg County. James Hunt at the Kentucky Utilities Building, Court Square, Greenville, Kentucky, may be contacted regarding the potential interst of Kentucky Utilities. His phone number is 502-338-3606. In Central City, Kentucky, contact the plant manager at 502-754-4541. The Big Rivers Power Plant is 
William Brothers Engineering Company

February 4, 1981

Page 2

still under construction at this time and we are not aware as to the person in charge at this time. I am sure any communication could be directed by letter to Calhoun, Kentucky, and it would get to the proper source.

Locally here, you may contact our County Judge, Honorable Robert Draper, 502-338-2520. You may also contact the Chamber offices directly, Central City being 754-2360, and Greenville being 338-5422. The Chamber President in Central City is Mike Payne and his number is 754-3300. The Chamber President in Greenville is Rev. Charles Midkiff and his office number is $338-3453$.

Again we are very much interested in considering your proposal and talking to you. Please contact us if you have any questions and we hope to hear from you soon concerning this matter. If you would like to meet with us feel free to contact us.

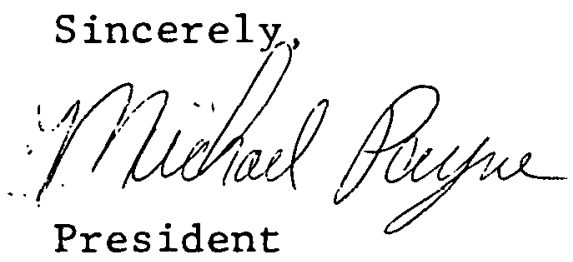




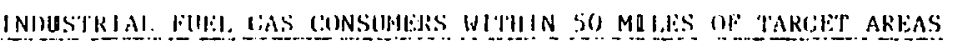

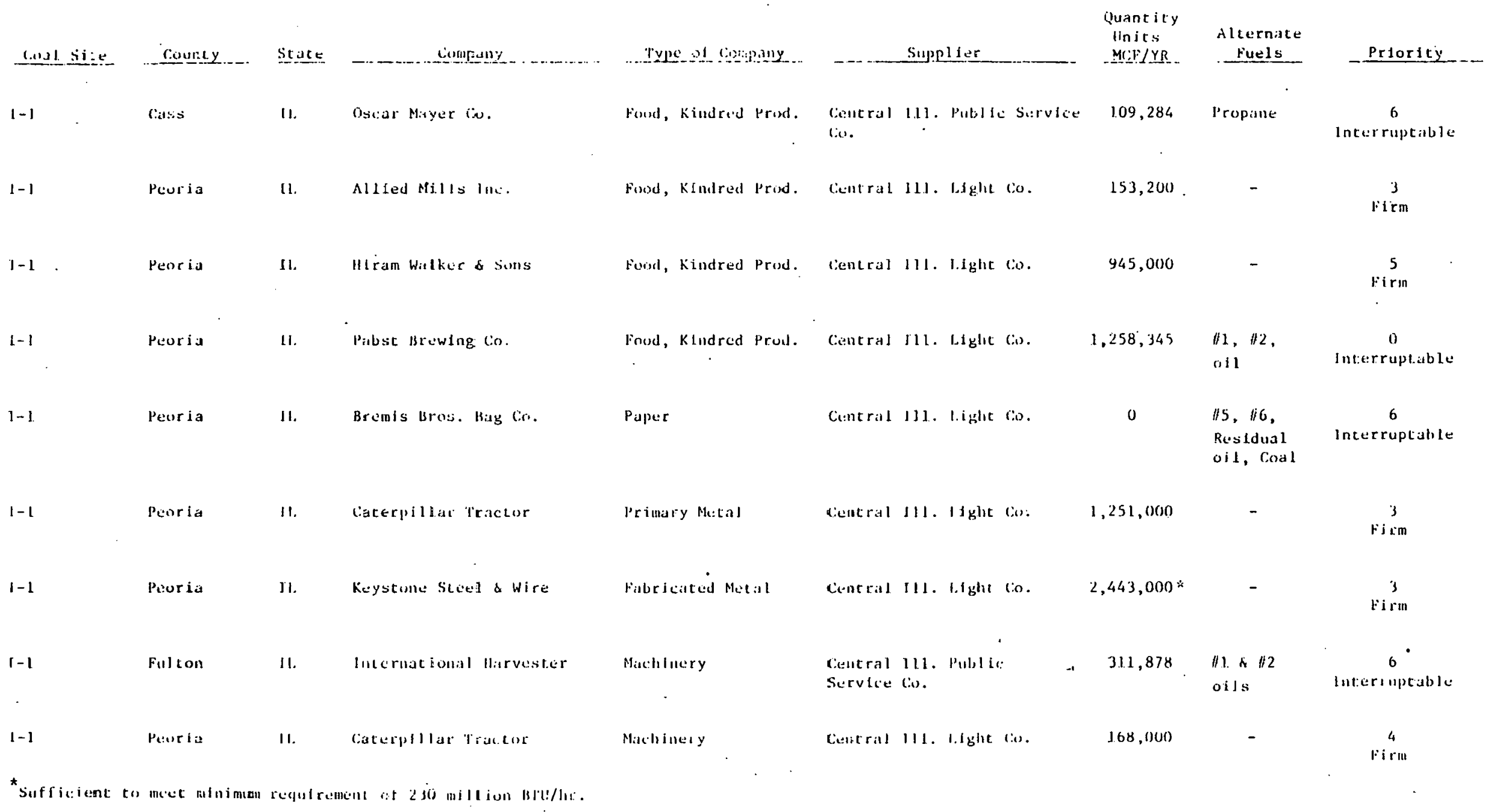


INUUSTRIAL HUHI CAS CONSUMERS WITIIIN SO MILES OF TARCEI AREAS

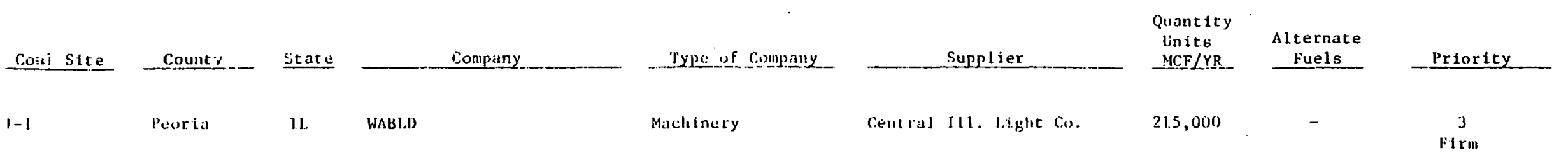




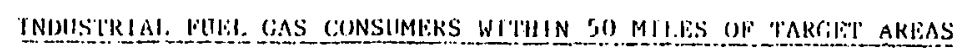

\begin{tabular}{|c|c|c|c|c|c|c|c|c|}
\hline Coul site & Count:.... & State & Compiny & Type al Conpany & Supplier & $\begin{array}{l}\text { Ruantity } \\
\text { Inits } \\
\text { MC.CLI요 }\end{array}$ & $\begin{array}{l}\text { Alternate } \\
\text { Fuels }\end{array}$ & Prior1ty \\
\hline$[\cdots 2$ & lihristian & IL & Continental Gratn co. & Fooil, Kindred Prod. & $\begin{array}{l}\text { Ceutral thl. Publis: } \\
\text { Service co. }\end{array}$ & 341,298 & $\begin{array}{l}\# 1, \text { \#2, \#s, } \\
\text { \#6 Residuai } \\
\text { oll }\end{array}$ & $\begin{array}{l}\quad 7 \\
\text { Interruptable }\end{array}$ \\
\hline $1-2$ & Ibouglais & II. & $\begin{array}{l}\text { Nat lonal Distillers and } \\
\text { Chenical Corp. }\end{array}$ & Chendcals & $\begin{array}{l}\text { Panhandle Eäslern Pince } \\
\text { Co. }\end{array}$ & $15,268,032 *$ & Propane; Coal. & $\begin{array}{c}n \\
\text { Interruptible }\end{array}$ \\
\hline $\mathrm{I}-\mathrm{2}$ & Mont gonery & I.I. & Eagle-Picher lind. & Chemicals & ll1tuols Power co. & 327,624 & Propane & $\begin{array}{c}0 \\
\text { Interruptuble }\end{array}$ \\
\hline $1-2$ & :lontgontry & I. & Hi.1 lshoro (ilass & Glass & I.1Jinois Puwer co. & 347,338 & $\begin{array}{l}\# 5, \| 6, \text { Resl- } \\
\text { dual }\end{array}$ & $\begin{array}{c}0 \\
\text { Interruptables }\end{array}$ \\
\hline$I-2$ & Mont gonery & LI. & Aluerican Smeliting & Primary Metal & 111inoss Power co. & 64,826 & $\|1 \&\| 2$ ofls & $\begin{array}{c}0 \\
\text { Interruptable: }\end{array}$ \\
\hline $1-2$ & Clıampaign & 11. & C1ifford - Jalcobs forging & Fabricated Miztal. & 111/nois luwer Co. & 300,216 & $\begin{array}{l}\text { \#5, \#6 \& } \\
\text { Restdual o11 }\end{array}$ & $\begin{array}{c}0 \\
\text { Interruptable }\end{array}$ \\
\hline
\end{tabular}

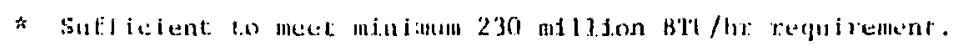




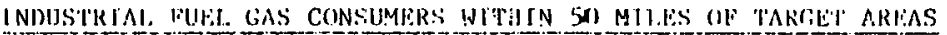

\begin{tabular}{|c|c|c|c|c|c|c|c|c|}
\hline Cosil site & Count?.... & State & Company & Type of Crompouy & Sujplier & $\begin{array}{l}\text { Quantity } \\
\text { Lnits } \\
\text { MCEF/YR }\end{array}$ & $\begin{array}{l}\text { Alternate } \\
\text { Fuels }\end{array}$ & Priority \\
\hline 1.-1. or $\Gamma-2$ & Tazewe 1 & IL & Ashland Chemical Co. & Agr. I.Ivestock & Central J11. light co. & 388,500 & - & $\begin{array}{l}3 \\
\text { Firm }\end{array}$ \\
\hline $1-1.2 \times r-2$ & Mclean & H. & $6-36-77-10.10$ & Food, Ktudred Proc. & Northern mil. Gas co. & 344,898 & - & $\stackrel{0}{n+r m}$ \\
\hline $1-1 \quad \& \quad I-2$ & Maton & IL & A.E. Stajey & Food, kindred prod. & Illdnois lower Co. & $7,416,777 *$ & - & $\begin{array}{l}0 \\
\text { Hirm }\end{array}$ \\
\hline $1-1<1-2$ & Matcon & IL & A.Ẹ. Staley Hig. Cu. & Food, Kindred Prod. & Tllluois power co. & 837,876 & $\begin{array}{l}\text { \#5, "16 Resi- } \\
\text { dual oil }\end{array}$ & $\begin{array}{l}- \\
\text { Interruptuble }\end{array}$ \\
\hline $1-1=1-2$ & Macom & ut. & Archer Dantels Mldland & Food, Kindred prod. & 1.11inols power co. & $1.95,980$ & - & $\underset{0}{0}$ \\
\hline $1-1 ; 5-2$ & Marcon & 1.1. & Archer baniels Midland-bast. & food, Kindred lirod. & Illlinols Power co. & 758,153 & $\begin{array}{l}\# 5, \| 6 \text { kest- } \\
\text { dual } 1 \text { ofl }\end{array}$ & 0 \\
\hline $1-1 \quad 1 \times 1-2$ & Maroun & 11. & Archer Danlel: Midland-West & Food, Kindred l'roil. & Irlinois Power Co. & $2,478,228 *$ & $\begin{array}{l}\text { \#5, \#6 Kest- } \\
\text { dual oil }\end{array}$ & 0 \\
\hline$I-1: \pm 1-2$ & Morgan & I.I. & Anderson (iaytun and Co. & liood, Kindred prod. & $\begin{array}{l}\text { l'aubindle Eastern Pine } \\
\text { Co. }\end{array}$ & $1.08,369$ & $\begin{array}{l}\|5, \# 6,\| 1 \\
\text { Kesidual } \\
\text { oil. Propine }\end{array}$ & $\begin{array}{c}0 \\
\text { Interruptiable }\end{array}$ \\
\hline $1-1$ \& $1-2$ & Morgatu & IL & Carmation Co. & Food, Kindred lerol. & $\begin{array}{l}\text { Pinluandle fiastern bine } \\
\text { co. }\end{array}$ & $1 y 5,644$ & Propane & $\begin{array}{c}0 \\
\text { Interruptabse }\end{array}$ \\
\hline
\end{tabular}




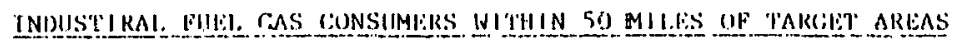

\begin{tabular}{|c|c|c|c|c|c|c|c|c|}
\hline Coal site & County & state & Conpany & Type of company & Supplier & $\begin{array}{l}\text { Quantity } \\
\text { Units } \\
\text { MCF/YR }\end{array}$ & $\begin{array}{l}\text { Alternate } \\
\text { Fuels }\end{array}$ & Priorlty \\
\hline $1-1 \& \quad \& \quad 1-2$ & Singomill & 11. & Pillsbury co. & Fond, Kindred l'rod. & $\begin{array}{l}\text { Cenrral T1L. Public } \\
\text { Service Co. }\end{array}$ & $21.1,000$ & - & $\begin{array}{c}3 \\
\text { lisin }\end{array}$ \\
\hline$I-1 \& 1-2$ & 'lazewel 1 & n. & American Dist illing Cos. & Food, Kindred Prod. & $\begin{array}{l}\text { Cetutral Ill. Public } \\
\text { Service Co. }\end{array}$ & 484,500 & - & $\stackrel{3}{3}$ \\
\hline$\left[\begin{array}{llll}-1 & \& & 1-2\end{array}\right.$ & Tazewe! & II. & CPC International Inc. & lond, KIndred l'rod. & Central rll. Light co. & $6.13,100$ & - & $\begin{array}{c}3 \\
\text { Firin }\end{array}$ \\
\hline $1-1 \& 1-2$ & Motian & t... & Capltal Records & lumber, Wood Irodurtes & Tllinois power cu. & 121,025 & $\|1 \&\| 201.1$ & $\begin{array}{c}0 \\
\text { Pirm }\end{array}$ \\
\hline $\begin{array}{l}\text { 1.- }-1 \& 1-2 \\
\therefore\end{array}$ & Christian & II. & Hopper Paper los. & Paper & $\begin{array}{l}\text { Central Ill. Public } \\
\text { Service Co. }\end{array}$ & $\begin{array}{l}6,691,536^{*} \\
\text {. }\end{array}$ & $\begin{array}{l}\|5 \&\| 6, \\
\text { Residual } \\
\text { ofl. }\end{array}$ & $\begin{array}{c}0 \\
\text { Interruptable }\end{array}$ \\
\hline $1-1,1-2$ & liazumell & Il. & Quaker Oat $=\mathrm{Co}$. & Paper. & Centeral 111 . I.tght (o. & 252,000 & - & $\stackrel{3}{3}$ \\
\hline $1-1 \leqslant 1-2$ & Morgan & 11. & National starch prod. & Chemicinls . & $\begin{array}{l}\text { central lll. Pablle } \\
\text { servilce co. }\end{array}$ & 161,753 & - & $\stackrel{3}{\text { Fi.rm }}$ \\
\hline $1-1 \& 1-2$ & Sinnsimon & li. & Burdon los. & Chte:uicons & Illinuis Prower (do. & 461,237 & $\begin{array}{l}\text { - } \\
\text { H5, } \| 6 \text { \& } \\
\text { Residual }\end{array}$ & $\frac{0}{\text { Incerruptable }}$ \\
\hline $1-1 \& 1-2$ & Me:Let:itt & II. & $6-33-7 k-2760$ & Kubber & Northern 1L1. Gias Co. & 170,364 & - & Pi riil \\
\hline
\end{tabular}




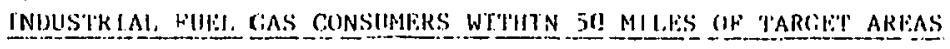

\begin{tabular}{|c|c|c|c|c|c|c|c|c|}
\hline Coal Site & Count:y & State & _- Company & Iype of Compnny & Supplier & $\begin{array}{l}\text { Quantity } \\
\text { Unit:s } \\
\text { MCF } /: R\end{array}$ & $\begin{array}{l}\text { Alternate } \\
\text { Fuels } \\
\end{array}$ & Prioricy \\
\hline$r-1 \& 1 .-2$ & Macon & IL & Firestone Tire \& Rubber to. & Rubter & Tllinois power co. & $586,58.1$ & $\begin{array}{l}\# 5, \| 6 \& \\
\text { Restdual } \\
011\end{array}$ & $\begin{array}{c}0 \\
\text { Interruptable }\end{array}$ \\
\hline $1-1.8 \quad[-2$ & I.oganl & 1.1. & Obear-Nesler Glass & Giluss & Central 1.1. l.Lght: co. & 829,000 & - & 3 \\
\hline $1-1 \& 1-2$ & Longan & 11. & PPG Industries & Ciluss & Central ill. Light Co. & 205,500 & -- & $\begin{array}{l}3 \\
\text { FirmII }\end{array}$ \\
\hline$I-1 \quad \& \quad 1-2$ & Macun & 1.1. & Piteslurgli plate Class Co. & Glasss & Illinols Power Co. & $1.275,867$ & $\|1 \&\| 2$ oll & $\begin{array}{l}0 \\
\text { lirm }\end{array}$ \\
\hline $1-1 \& 1-2$ & Dewjit: & Il.. & kevere Copper \& Brass & Prlimary Metial & Ll.t inuls Power co. & 149,281 & $\begin{array}{l}\text { \#1 \& } \| 2 \text { vils, } \\
\text { Propatne }\end{array}$ & ' \\
\hline $1-1 \& 1-2$ & Macon & 11. & Wagner liasting & Prillary Metal. & llinols perwer cos. & 388,288 & -. & $\begin{array}{c}0 \\
\text { li irm }\end{array}$ \\
\hline $1-1$ \& $1-2$ & Mis:lean & 11. & $6-.15-77-0950$ & Niaclitinery & Northern tll. Gas co. & 224,737 & - & $\begin{array}{l}0 \\
\text { li i rm }\end{array}$ \\
\hline $1-1<1-2$ & Mratout & I.L. & York Div. Burg Warner & Machinery & I1] inolis Puler co. & $1.19,633$ & $\begin{array}{l}\# 5, \| h, \text { Resi- } \\
\text { Jual }\end{array}$ & $\begin{array}{l}0 \\
\text { - }\end{array}$ \\
\hline $1-1 \& 1 \cdots$ & Silngillum & 11. & $\begin{array}{l}\text { Fiat-Allis canslruetion } \\
\text { Mathinery }\end{array}$ & Machinecy & 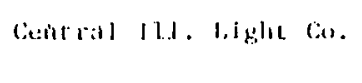 & 0 & $\begin{array}{l}\text { \#5, H6, Resi- } \\
\text { dhat wil. }\end{array}$ & $\begin{array}{l}\text { - } \\
\text { ratectuptablats }\end{array}$ \\
\hline
\end{tabular}




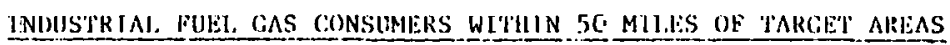

\begin{tabular}{|c|c|c|c|c|c|c|c|c|}
\hline Coal Site & County & State & Company & Type of Company & Suppl Ler & $\begin{array}{l}\text { Quantity } \\
\text { Untts } \\
\text { MCF/YR }\end{array}$ & $\begin{array}{l}\text { Alternate } \\
\text { Fue1s }\end{array}$ & Priority \\
\hline $1-1 . \& \quad 1-2$ & Simgiunon & 11. & $\begin{array}{l}\text { Plat-A1.1 is Construction } \\
\text { Machinery }\end{array}$ & Maclinery & Central Ill. Light co. & 330,000 & $\therefore$ & $\begin{array}{l}3 \\
\text { Firn }\end{array}$ \\
\hline $1-1$ \& $1-2$ & Pazcwell & IL & Caterpillar co. & Machinery & Morlon Mun Cas Co. & 86,190 & $\|1\| .2011 \mathrm{~s}$ & $\stackrel{0}{0}$ \\
\hline $1-1 . \& 1-2$ & [azewed.]. & II. & Caterpillar lio. & Maclinery & Central 111 . Light Co. & $1,232,000$ & - & virm \\
\hline $1-1 \quad \dot{\alpha} \quad 1-2$ & Mclcan & 1I. & $6-08-80-5290$ & $\begin{array}{l}\text { Electrical, Buerero- } \\
\text { nde Mach. }\end{array}$ & Northern 111. Cas. Co. & 128,829 & - & 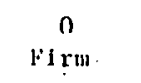 \\
\hline $1-1 . \leq I-2$ & Sangamon & J.L & Sangomo Weston & Precistun Eg. & Central. T11. I.Ight Co. & 116,400 & - & $\begin{array}{c}3 \\
\text { Firm }\end{array}$ \\
\hline
\end{tabular}




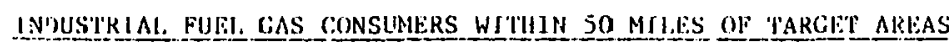

\begin{tabular}{|c|c|c|c|c|c|c|c|c|}
\hline Coal Site & Councy & State & Conpany & Type of Cimpany & Supplier & $\begin{array}{l}\text { Quantity } \\
\text { Linits } \\
\text { MCF/YR_- }\end{array}$ & $\begin{array}{l}\text { Alternate } \\
\text { fuels }\end{array}$ & Priority \\
\hline I. $-3,4,5,6$ & Perry & II. & Duquisin Packling co. & Food, Kindred Prod. & $\begin{array}{l}\text { Central 111. Publlte } \\
\text { Service cu. }\end{array}$ & 75,639 & $\|1\|$,2 o1.1 & $\begin{array}{c}6 \\
\text { [nterruptable }\end{array}$ \\
\hline$[-3,4,5,6$ & WEZL Lamson & I $\mathbf{L}$ & Libby Canting co. & Fond, Kindred Prod. & Morton Mun Cas to. & 25,310 & $\# 1, \| 2$ oll & $\begin{array}{c}0 \\
\text { Firm }\end{array}$ \\
\hline $1 .-3,4: 5,6$ & Jackson & IL. & Tuck Industiles & Text tle Mill. & $\begin{array}{l}\text { Central } 111 \text {. Publis: } \\
\text { Service Co. }\end{array}$ & 84,270 & $\begin{array}{l}\text { \#5, } 116 \text { Resi- } \\
\text { dual }\end{array}$ & $\begin{array}{l}\quad 6 \\
\text { Lnterruptable: }\end{array}$ \\
\hline $1-3,4,5,6$ & Wi.l] Lamson & IL. & Allen findistries, lnc. & Winished fibrics & $\begin{array}{l}\text { Central lll. Public } \\
\text { Service co. }\end{array}$ & $9 y, 204$ & Propane & $\begin{array}{c}6 \\
\text { Interruptablet }\end{array}$ \\
\hline $1-3,4: 5,6$ & Kjehland & H4. & Auerjcian Machine \& loundry & Fabricated Metal & Eastern ItL, Gas \& Electris & 92,973 & $\begin{array}{l}\|1 \&\| 2 \text { oils, } \\
\text { Propane }\end{array}$ & $\stackrel{2}{2}$ \\
\hline $1-3,4,5,6$ & Will iamson & [L. & $\begin{array}{l}\text { Horge co. Div. - } \\
\text { Fedders corp. }\end{array}$ & $\begin{array}{l}\text { Electrifcal, Electro- } \\
\text { nic Mach. }\end{array}$ & $\begin{array}{l}\text { Central. 111. Public Service } \\
\text { Co. }\end{array}$ & 167,102 & Proparie & $\begin{array}{l}6 \\
\text { Interruptable }\end{array}$ \\
\hline
\end{tabular}




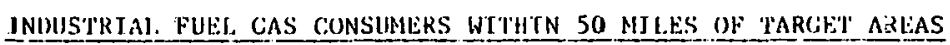

\begin{tabular}{|c|c|c|c|c|c|c|c|c|c|c|}
\hline Coal Site & County & State & Company & Type of comp & vany & & Supplter & $\begin{array}{l}\text { Quantity } \\
\text { linits } \\
\text { MC:YLP. }\end{array}$ & $\begin{array}{l}\text { Alternate } \\
\text { Fuels } \\
\end{array}$ & Priority \\
\hline$k-1$. & Havless & KY & Owensboro liain co. & rood, Kindred & Prud. & Western & Kentucky Cas co. & 263,457 & $\begin{array}{l}\text { H, W2 oils, } \\
\text { Prupane }\end{array}$ & $\begin{array}{c}3 \\
\text { firm }\end{array}$ \\
\hline$k-1$. & Diaviess & KY & Pinkertion Tobacio co. & Tobacco Mfg. & & Western & Kentucky Gas co. & 76,594 & $\Downarrow 1, \| 2$ oll & $\stackrel{3}{3}$ \\
\hline$k-1$ & Warren & $K Y$ & $\begin{array}{l}\text { Flrestone Synthetic } \\
\text { Fibers and lextilt }\end{array}$ & Textile Mill & . & Western & Kentucky Cas co. & 124,836 & Propane & $\stackrel{2}{2}$ \\
\hline$k-1$ & llancock & KY & Western Kraft Corp. & Paper. & & Western & Kentucky Gas co. & $701,31.5$ & $\begin{array}{l}\text { \$5, \$6 \& Resi- } \\
\text { dual of } 1\end{array}$ & $\stackrel{s}{\text { Firmi }}$ \\
\hline$k-1$ & Dáviess & KY & W.R. Grace \& co. & Chemicals & & Western & Kentucky Gass co. & 207,843 & $\Downarrow 1, \| 2$ oil & $\stackrel{3}{\text { Pi.rm }}$ \\
\hline$k-1$ & Caldwe] 1 & KY & General l's re \&ubber cu. & Rubber & & Westurn & Kentucky lias co. & 0 & $\$ 1, \| 2$ ofls & $\begin{array}{c}5 \\
\text { firm }\end{array}$ \\
\hline$k-1$ & Daviess & KY & $\begin{array}{l}\text { Owensburo brick and t'tle } \\
\text { Co. }\end{array}$ & Stont & $\cdot$ & Western & Kentucky cias co. & 482,570 & $\|1 \&\| 2$ ol.1s & $\begin{array}{c}2 \\
\text { Pirin }\end{array}$ \\
\hline$k-1$ & Hancoct. & KY & Ancijcin olcan tile co. & Stune & & $\begin{array}{l}\text { citcy of } \\
\text { Gass }\end{array}$ & L.ewisporte Natural & 212,648 & $\|1 . \&\| 2$ oils & $\stackrel{2}{\text { Hirm }}$ \\
\hline$k-1$ & Christian & KY & Phelps hodge curp. & Pritualcy Metais & & Wescern & Kentrutky ciass do. & 425,128 & - & $\stackrel{2}{2}$ \\
\hline
\end{tabular}


JHUUSTK IAI. FUEI GAS CONSUNERS WITHIN 50 MIIES OF MARGET AREAS

\begin{tabular}{|c|c|c|c|c|c|c|c|c|}
\hline Coill Site & County _- & scate & Company & Type of Company & Supplier & $\begin{array}{l}\text { Quantity } \\
\text { Units } \\
\text { MCF/YR }\end{array}$ & $\begin{array}{l}\text { Alternate } \\
\text { Fuejs }\end{array}$ & Priority \\
\hline$k-1$ & Davless & $\mathrm{kY}$ & Aluminum Service co. & Primary Metal & Western Kentucky lias co. & 130,942 & $\|1 \&\| 2$ oils & $\begin{array}{l}3 \\
\text { PI }\end{array}$ \\
\hline $\mathrm{K}-1$ & Daviess & KY & Green RIvEr Steel Corp. & Primary Metal & Western Kentucky las Co. & 847,156 & $\| 1 \& \# 2$ olls & $\begin{array}{c}2 \\
\text { Firmil }\end{array}$ \\
\hline $\mathrm{k}-1$ & Daviess & KY & Ohio valley forging & Primary Metal & Wistern Kentucky las co. & 153,327 & $\begin{array}{l}\text { "1\& \#2 olls, } \\
\text { Propane }\end{array}$ & $\begin{array}{c}3 \\
\text { Firin }\end{array}$ \\
\hline$k-1$ & Hancock & KY & $\begin{array}{l}\text { Martín Marletta Aluminum } \\
\text { Co. }\end{array}$ & Prinary Metal & Western Kentucky Gas Co. & $2,246,096^{*}$ & $\|1 \&\| 2$ o11s & $\stackrel{2}{2}$ \\
\hline$k-1$ & Huncock & KY & Nat Ional Steci Corp. & Prinary Metal & Orbte cas co. & 449,266 & $\|1 \&\| 2$ oils & $\begin{array}{c}3 \\
\text { Pírm }\end{array}$ \\
\hline$k-1$ & Logian & KY & $\begin{array}{l}\text { Rockuell Manofacturlag } \\
\text { Co. }\end{array}$ & Primary Metal & Western Kentucky Cias Co. & 181,554 & $\|1 \&\| 2$ of $1 \mathrm{~s}$ & $\begin{array}{c}2 \\
\text { Firm }\end{array}$ \\
\hline$k-1$ & Culdweld & KY & Crinnelil liorp. & Fabricated Netal & Western Kentucky lias lo. & 90,098 & $\|1 \&\| 2$ o11s & $\underset{i \mathrm{irn}}{2}$ \\
\hline$k-1$ & Hancock & KY & $\begin{array}{l}\text { Natfonal southwire } \\
\text { Aluminum aco. }\end{array}$ & Fibricated Metal & Orbit las co. & 367,584 & $\begin{array}{l}\text { \#1\& \#2 oils, } \\
\text { Propane }\end{array}$ & $\stackrel{3}{\text { Firm }}$ \\
\hline$k-1$ & Hanconek & KY & Southwire Co. & Fibricated Metat & Orbit fias co. & 59,150 & $\begin{array}{l}\|1 \quad \& \quad\| 2 \text { ofits, } \\
\# 4 \text { oll. }\end{array}$ & $\begin{array}{l}3 \\
31 \mathrm{r} m\end{array}$ \\
\hline
\end{tabular}


INDUSTRIAL. FULL GAS CONSUAHRS WITHIN 50 MILES OF TARCEET AREAS

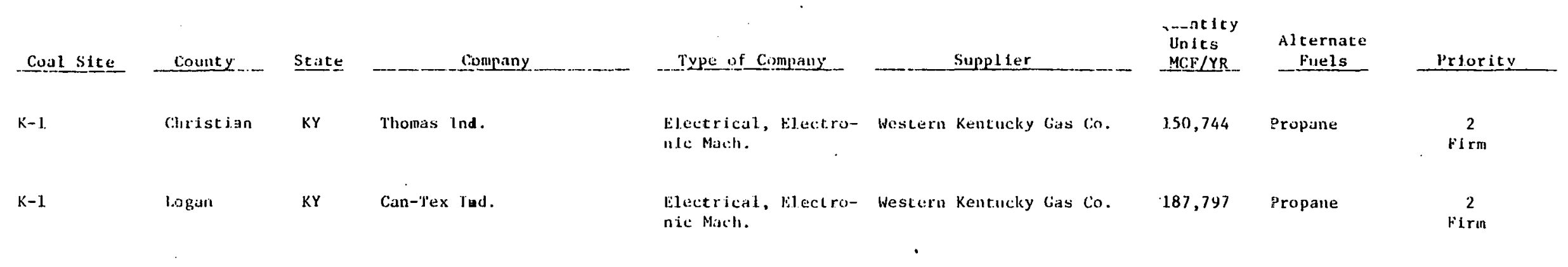


INIOUS":KIAI. HUEL GAS CONSUNERS WITHIN 50 FLILS OF TARCLT AREAS

\begin{tabular}{|c|c|c|c|c|c|c|c|c|}
\hline Coal site & County ... & State & Company. & Type of Company & Supplier. & $\begin{array}{l}\text { Quantity } \\
\text { Units } \\
\text { MC:F/YR }\end{array}$ & $\begin{array}{l}\text { Alternate } \\
\text { Fuels } \\
\end{array}$ & Priority \\
\hline$k-2$ & l.alwrence & KY & Luatsa Carpet Mills, lace. & Text l. $=$ M111 & $\begin{array}{l}\text { Columbia has of Kentucky, } \\
\text { Inc: }\end{array}$ & 86,666 & $\begin{array}{l}\text { Propane } \| 5, \\
\text { \#b ofl, resi- } \\
\text { dual oil }\end{array}$ & $\begin{array}{l}0 \\
\text { Firin }\end{array}$ \\
\hline
\end{tabular}


INDUSIRIAI. FUEL CAS CONSUMERS WITUIIN 50 MILES OF TARCET AREAS

\begin{tabular}{|c|c|c|c|c|c|c|c|c|}
\hline Coal site & County & State & Corpany & Type of Company & Supplier & $\begin{array}{c}\text { Quantity } \\
\text { Units } \\
\text { MCF/YR }\end{array}$ & $\begin{array}{c}\text { Alternate } \\
\text { Fuels }\end{array}$ & Priority \\
\hline $0-1$ & 'luscarawas & OII & lioremost lioods & fuod, KIndred Prod. & Fast obio bas lo. & 138,646 & $\|1\|$,2 oils & $\stackrel{2}{2}$ \\
\hline
\end{tabular}




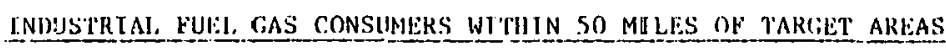

\begin{tabular}{|c|c|c|c|c|c|c|c|c|}
\hline Coal Site & County & State & Coupany & Iype of Conipany & Supplier & $\begin{array}{l}\text { Quantity } \\
\text { linits } \\
\text { MCF/YR }\end{array}$ & $\begin{array}{l}\text { Alternate } \\
\text { Fuels }\end{array}$ & Priority \\
\hline $0-1,2$ & Be.linont & Mi & Imperfal Clatss & Class & Columbla lias of onlo & 314,969 & $\# 1 \& \# 2$ olls & $\stackrel{0}{0}$ \\
\hline $0-1,2$ & Be.lmont & $\mathrm{CH}$ & Rodefer Glass co. & Glass & Columbia Gas of ohto & $151, .575$ & Propane & $\stackrel{0}{\text { firm }}$ \\
\hline
\end{tabular}


INIUUSTRIAL FUEI. GAS CONSUMERS WITHIN SO MTIES OE TARGEI AKLAS

\begin{tabular}{|c|c|c|c|c|c|c|c|c|}
\hline Coa: Site & Count & State & _ Company & Type of Company & Supplier & $\begin{array}{l}\text { Quantity } \\
\text { Units } \\
\text { MCF/YR }\end{array}$ & $\begin{array}{c}\quad \because \\
\text { Alternate } \\
\text { Fuels } \\
\end{array}$ & Priority \\
\hline $0-1,2,3$ & Washifington & on & Sperry kemington & Furniture & River Gias lio. & 937,658 & $\|1 \delta\| 2$ oll & $\begin{array}{l}3 \\
\text { Wirm }\end{array}$ \\
\hline $0-1,2,3$ & Washlngton & OII & Anerican cyanamid cos. & Clleiniceals & Kiver las cio. & 162,065 & $\| 1 \& \# 2$ oll & $\begin{array}{c}0 \\
\text { pirim }\end{array}$ \\
\hline $0-1,2,3$ & Wasslington & Oll & Ashu and themical $\mathrm{Co}$. & Chenicals & Klver lias co. & 116,485 & $\# 1 \& \# 2 \quad 011$ & $\begin{array}{c}0 \\
\text { Firm }\end{array}$ \\
\hline$(1-1 ;, \ddot{2}, 3, \because, \cdots$ & Wasslington & OH & Shel.l. Cheminal co. & Chemileals & River lias (n). & 391,399 & - & $\begin{array}{l}0 \\
\text { Prom }\end{array}$ \\
\hline $01-1.2,3$ & liarrisuli & $\mathrm{UH}$ & Bowerston Shak co. & stone & Ellis 'l. Myers Gats cu. & 104,327 & $\|1 \&\| 2011 \mathrm{~s}$ & $\stackrel{2}{\text { Firm }}$ \\
\hline $0-1.2,3$ & Hatrisen & OH & Scio pottery co. & stune & Columbia lias of Ohio & 196,760 & Propanc. & $\begin{array}{c}0 \\
\text { lit } i n\end{array}$ \\
\hline $0-1.2,3$ & Mu::k inguun & OHS & Brockivay alats: co. & (ilass & National fass $\&$ ill corp. & $1,577,000$ & $\|1 \&\| 2$ oils & $\begin{array}{c}2 \\
\text { Fjin }\end{array}$ \\
\hline $0-1,2,3$ & Musk ingum & OH & Nelsun Me soy Pottery & scone & Natlional lats \& lit corp. & 173,000 & - & ${ }_{\substack{2 \\
\text { limm }}}$ \\
\hline$(1-1,2,3$ & W:1s/oingtu川 & (111) & Anchar Hovkins corp. & sicuns: & Cias Irallspourt Ine. & $2,10 \%, 0010 \%$ & $\| 1$ \& $\| 2$ wil:i & $\mathrm{Fin}^{2}$ \\
\hline $\begin{array}{l}0-1.2,3 \\
\therefore \text { suftit: }\end{array}$ & 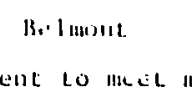 & in! & 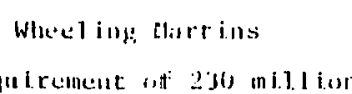 & Pritnitry Mutial & Culumbla lias of Uhin, Lur. & 464,595 & - & $\stackrel{0}{\prime \prime}$ \\
\hline
\end{tabular}




\section{INUISTR IAL PUIL GIAS CONSUNERS WITHUN 50 MIIES OP TARCET AKEAS}

\begin{tabular}{|c|c|c|c|c|c|c|c|c|c|c|}
\hline Coul site & Counts & State & Company & Type of company & Supplier & $\begin{array}{l}\text { Quantity } \\
\text { Units } \\
\text { MCF/YR }\end{array}$ & & $\begin{array}{l}\text { ernate } \\
\text { uels }\end{array}$ & Priorte & \\
\hline $0-1,2,3$ & Monroe & OH & Consolidared Alumfium Corp. & Primary Metial & columbia cias of ohdo, Inc: & $4,048,157 \star$ & $\begin{array}{l}\text { \#1 \& } \\
\text { Prop: }\end{array}$ & $\begin{array}{l}\text { H2 ofls, } \\
\text { ane }\end{array}$ & $\begin{array}{c}0 \\
\text { Firm }\end{array}$ & \\
\hline$(1-1,2,3$ & Mussk fingunn & OHI & Ohio Ferro Alloy & P'imary Metal & National Gas $x$ oil corp. & 124,500 & $\# 18$ & $\# 2$ oi.1s & $\underset{2}{2}$ & \\
\hline $0-1,2,3$ & WaslitingLon & OII & 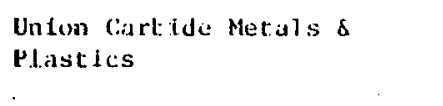 & Primary Metal & River Gas lu. & 686,287 & $n 18$ & $\# 2$ otls & $\begin{array}{c}0 \\
\text { pirm }\end{array}$ & \\
\hline $0-1,2,3$ & Guernsey & OII & Cyclops Cerp. & Fabrleated Netat & Culumbial Gas of Ohio, linc. & 100,095 & & - & $\begin{array}{c}0 \\
\text { pirin } \\
\text { pir }\end{array}$ & \\
\hline $0-1,2,3$ & Muskingutu & OHI & Armco steel curp. & Pubricated Metal & Nat lonal Gas \& 011 corp. & 355,000 & & - & $\begin{array}{l}\cdot 2 \\
\text { Hirum }\end{array}$ & \\
\hline $0-1,2,3$ & MuskingLiu & uil & Burrahaten corp. & labricated Metal & Nat lonal Gas \& oll corp. & 131,000 & $11.1 \&$ & $\# 2$ vils & $\stackrel{2}{2}$ & \\
\hline$(1-1,2,3$ & Guernscy & oH & Nat ional Cash kegister & Machifnery & 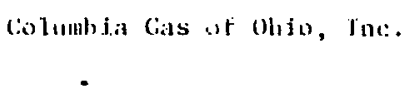 & 31,380 & in $1 \&$ & $\# 2$ olls & $\begin{array}{c}0 \\
\text { rition } \\
0\end{array}$ & - \\
\hline$(1-1,2,3$ & Giverusey & OHI & Chanplom spark llag, co. & $\begin{array}{l}\text { Fiectrlasl, - Bjectro- } \\
\text { nic Mach. }\end{array}$ & Columbla Gils: of Ohio & 100,000 & & - & $\begin{array}{c}0 \\
\text { Firm }\end{array}$ & \\
\hline $0-1,2,3$ & Gilerntiey & OH & Hunileoul Beasth biv. & $\begin{array}{l}\text { Blectriall, Hectern- } \\
\text { nic: Macil. }\end{array}$ & Colunhla Gils of Oloin & 73,853 & & - & $\begin{array}{c}0 \\
\text { Firm }\end{array}$ & \\
\hline
\end{tabular}


INI!ISTHIAI. FUEL GAS CONSUMIERS WITHIN 5.) MLILS OF IARCLET AREAS

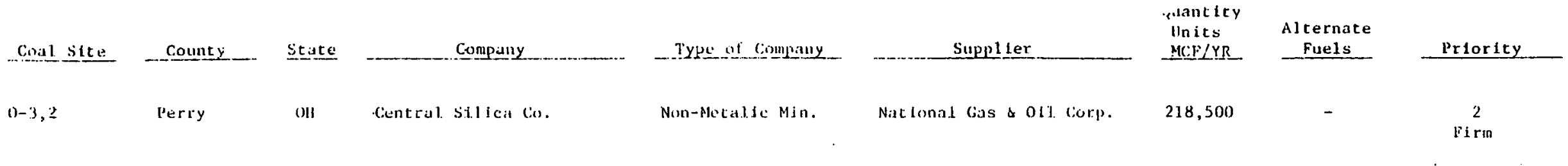


INDUSTRIAL VUEL CAS CONSUMEKS WTIHIN SO MILES OE J'AKCET AREAS

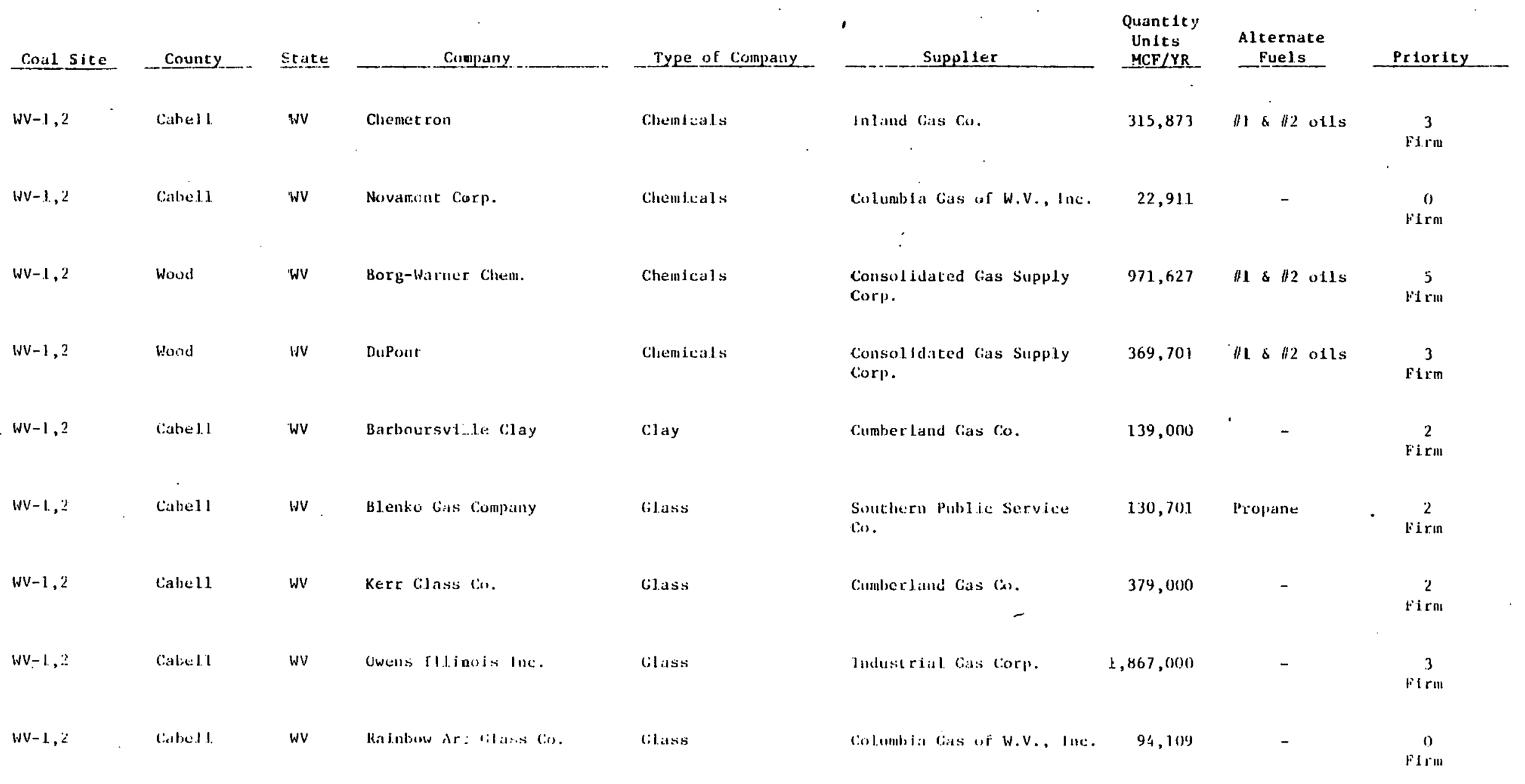




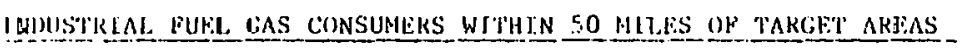

\begin{tabular}{|c|c|c|c|c|c|c|c|c|}
\hline Coal Site & County & State & __osprany & Iype of coupany & suppl ler & $\begin{array}{l}\text { Quantity } \\
\text { Units } \\
\text { MCF/YR }\end{array}$ & $\begin{array}{l}\text { Alternate } \\
\text { Fuels } \\
\end{array}$ & Prioricy \\
\hline$W V-1,2$ & Cabte 1.1 & WV & Conners stecl co. & Primary Meral & Cumberland lias co. & 292,000 & - & ${ }_{\text {Firm }}^{2}$ \\
\hline WV-L, 3 & Cabcill. & WV & Hunt ington N.l loy & Primary Metal & Industrial las Corp. & 753,850 & - & $\begin{array}{c}3 \\
\text { Firm }\end{array}$ \\
\hline$w V-1,2$ & Cabel.J & WV & Houdallle Ind. Inc. & Transportation lig & Collumbia lits of iv. Va., Ine. & 92,300 & - & $\begin{array}{c}0 \\
\text { Firin }\end{array}$ \\
\hline$w V-1,2$ & Cabe J 1 & WV & ACF Industries & Misc. Mf & lnland lias Co. & 167,876 & $\# 1 \& \| 2$ oils & $\begin{array}{l}3 \\
\text { litm }\end{array}$ \\
\hline
\end{tabular}


INIIISTRIAL BUEL GAS CONSUNERS WIITIIN SO MILES OE LARGET AREAS

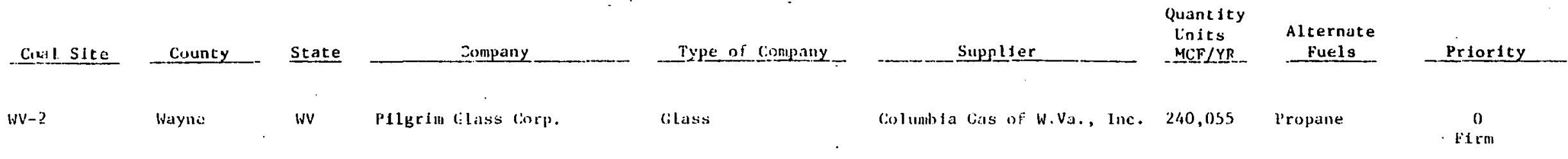


INIUISTR LAL. FUEI GAS CONSUMERS WETMN 5 C MTLLS OF TAKCLI AKEAS

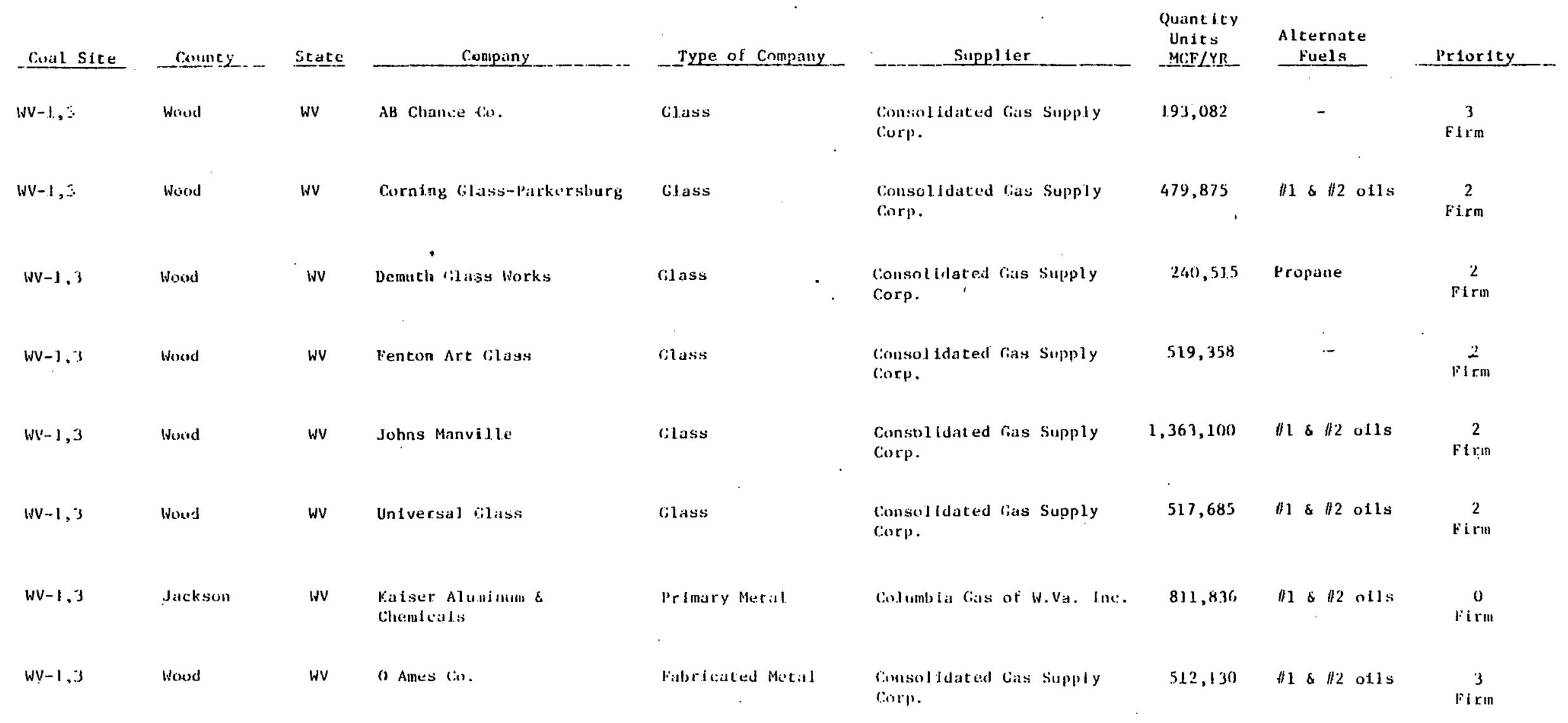




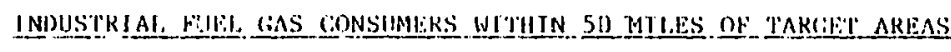

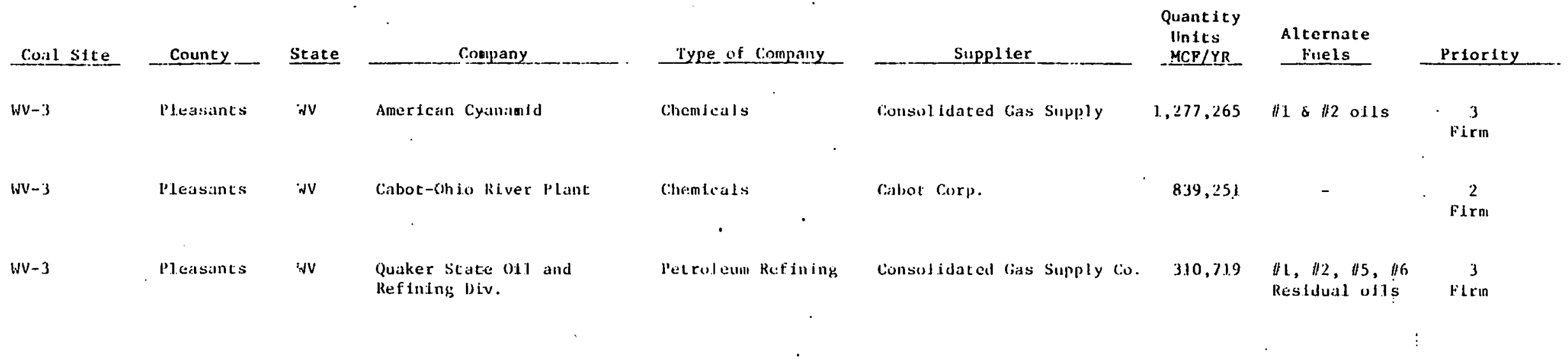


INDUSIRIAI, FUEI GAS CONSUMERS WITHIN SC MILES OF T'ARCEEI ARLAS

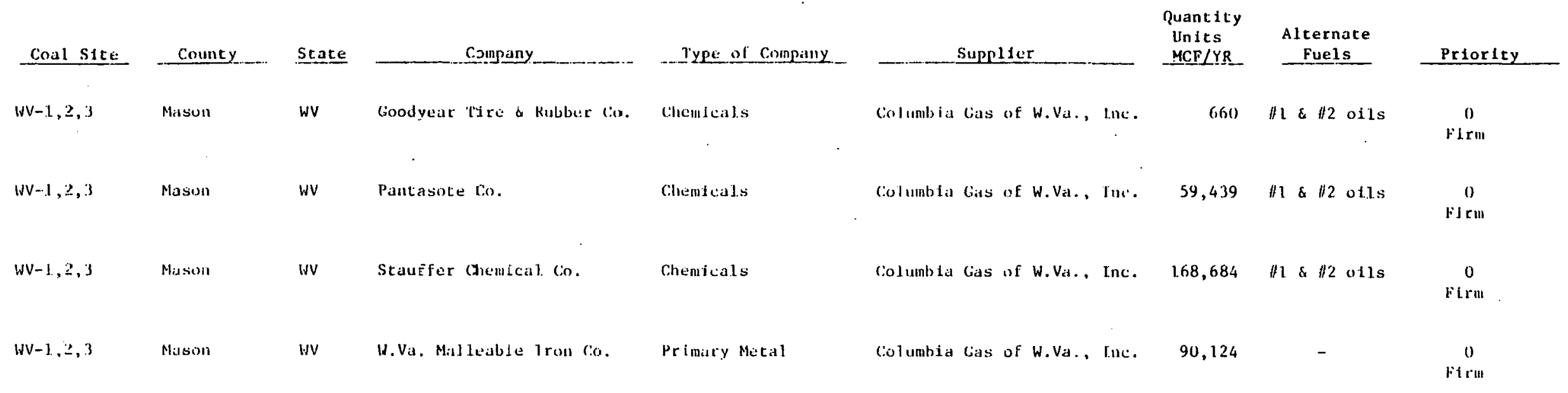




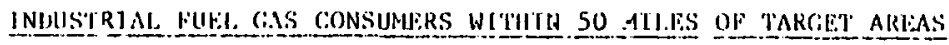

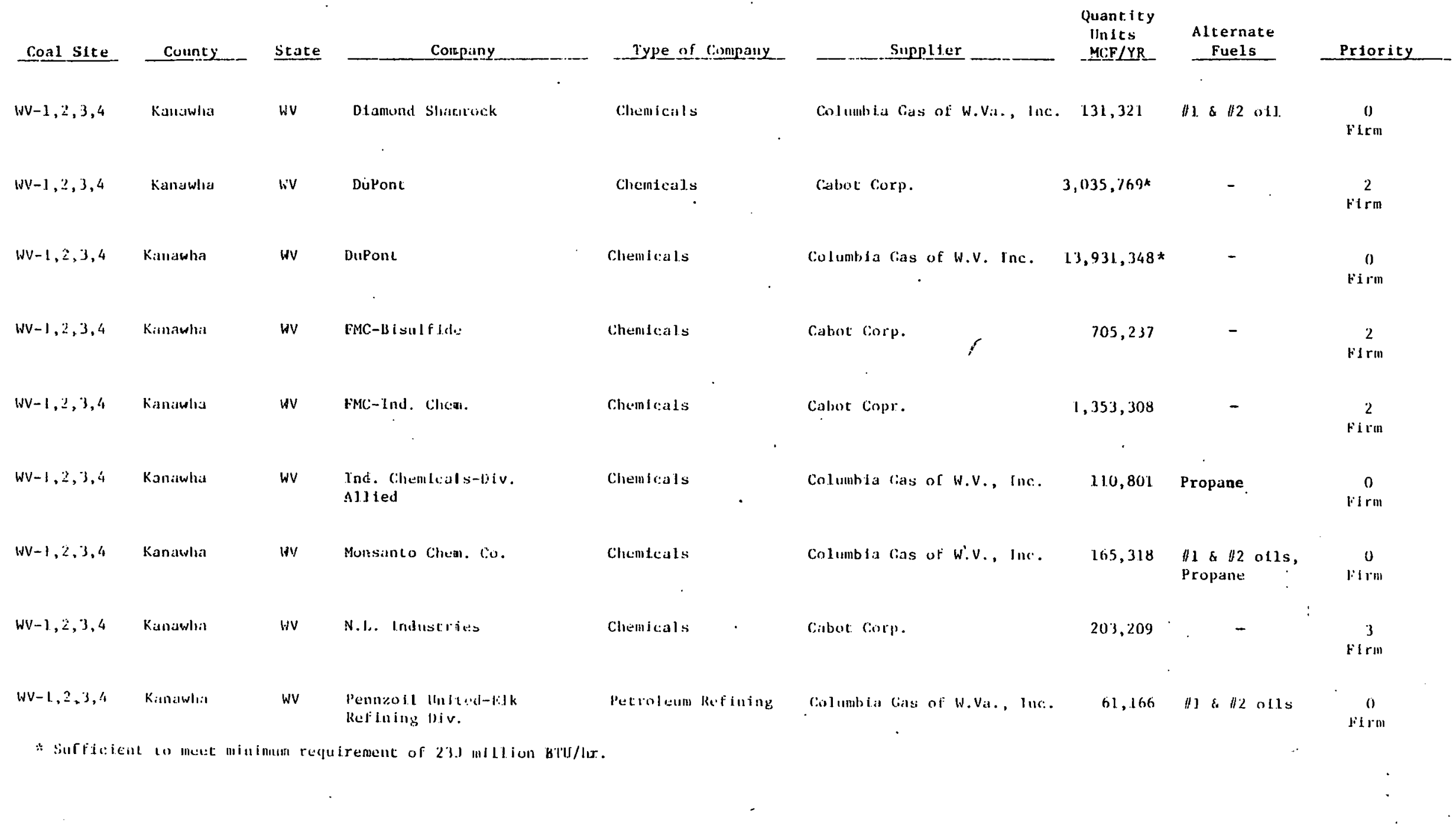




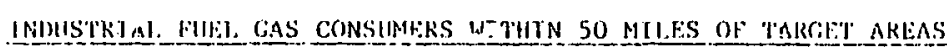

\begin{tabular}{|c|c|c|c|c|c|c|c|c|}
\hline Coal site & County & State & Conpany & _Type of Company & Supplier & $\begin{array}{l}\text { Quantity } \\
\text { Unlits } \\
\text { MCF/YR }\end{array}$ & $\begin{array}{l}\text { Alternate } \\
\text { Fuels }\end{array}$ & Priority \\
\hline$w V-1,2,3,4$ & Kan:iwlia & HV & Lubbey Owens Ford & Class & Industrlul lass corp. & $2,341,000^{*}$ & - & $\begin{array}{c}3 \\
\text { Firm }\end{array}$ \\
\hline$w V-1,2,3,4$ & K:Jna|w|u: & WV & True Tumper corp. & lobricated Metal. & Culsut Corp. & 163,774 & - & $\begin{array}{c}3 \\
\text { firin }\end{array}$ \\
\hline
\end{tabular}

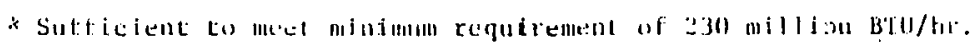




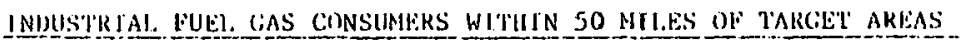

\begin{tabular}{|c|c|c|c|c|c|c|c|c|c|}
\hline Conal Sice & County & Stace & Conpany. & _Type of Company_ & Supplier & & $\begin{array}{l}\text { Quantity } \\
\text { Units } \\
\text { MCF/YR }\end{array}$ & $\begin{array}{l}\text { Alternate } \\
\text { Fuels } \\
\end{array}$ & Prlority \\
\hline$w V-4$ & llarrison & wV & Brockway ciass lio. & d:1as: & $\begin{array}{l}\text { Consolidated las } \\
\text { Curp. }\end{array}$ & Supply & $1,701,363$ & - & $\begin{array}{l}3 \\
\text { Firn }\end{array}$ \\
\hline$W V-4$ & Harrison & wV & Fourco Glass cu. & Giass & $\begin{array}{l}\text { Cunsulidated Cias } \\
\text { Corp. }\end{array}$ & Supply & $i, 178,470$ & - & $\stackrel{3}{\text { Firm }}$ \\
\hline$W V-4$ & Harrlion & WV & Meaduwbruek corp. & Primary Metal. & $\begin{array}{l}\text { Consolidated lias } \\
\text { Corp. }\end{array}$ & Supply & 489,820 & - & $\begin{array}{l}2 \\
\text { Pirm }\end{array}$ \\
\hline$W V-I_{a}$ & Harrisua & wV & UCC Carboa Div. & $\begin{array}{l}\text { Elcetrical, Ealectro- } \\
\text { nic Mach. }\end{array}$ & $\begin{array}{l}\text { Consolidated Cass } \\
\text { Corp. }\end{array}$ & Susply & 283,438 & - & $\begin{array}{l}3 \\
\text { Firm }\end{array}$ \\
\hline
\end{tabular}




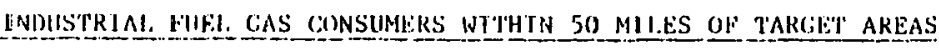

\begin{tabular}{|c|c|c|c|c|c|c|c|c|c|}
\hline Coull Site: & County & State & . & C.onneariny. & Type of Company & Supplier & $\begin{array}{l}\text { Quantity } \\
\text { Units } \\
\text { MCE } / Y R\end{array}$ & $\begin{array}{l}\text { Alternate } \\
\text { Fuels } \\
\end{array}$ & Prlority \\
\hline$(v v-1,3,4$ & le'wis & WV & Loute & Fil:A $=S$ & (alass & $\begin{array}{l}\text { Consoldiated lias supply } \\
\text { Corp. }\end{array}$ & 136,711 & - & $\stackrel{2}{2}$ \\
\hline$w V-1,3,4$ & Lew is & WV & W. vid. & Glass Sperialties & (ilass & $\begin{array}{l}\text { Consolldared Gas Supply } \\
\text { Curp. }\end{array}$ & 281,272 & - & $\stackrel{2}{2}$ \\
\hline$W V-1, \because, 4$ & Fayete & WV & Union & Carbidt: Corp. & P'rimary Metal & Cubot Corp. & $137,6.55$ & - & $\stackrel{2}{2}$ \\
\hline
\end{tabular}




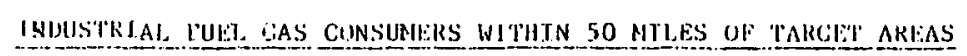

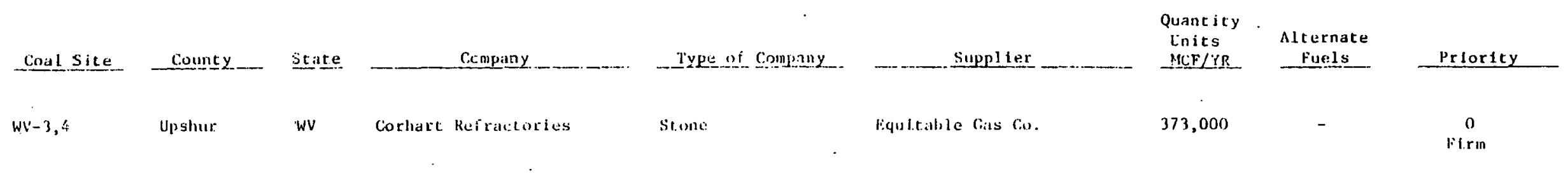


POHER PLANTS

\begin{tabular}{|c|c|c|c|c|c|c|c|c|c|c|}
\hline Cosel stee & State: & Souncy Code & Counte- & Plant/Addreese & Compenz/Addrees & Plent Location & sien & $\begin{array}{l}\text { Type } \\
\text { peste }\end{array}$ & Inel & Net. \\
\hline$k-1$ & $\mathbf{K Y}$ & 181 & oh10 & None & . & & & & & \\
\hline$k-2$ & wv & 047 & McDowe L1 & None & . & . & & & & \\
\hline $\mathrm{k}-2$ & wV & 059 & MIngo & None & & & & & & \\
\hline$k-2$ & $\mathbf{K Y}$ & 195 & P1ke & None & & & & & 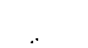 & \\
\hline$w V-1,3$ & wv & 007 & Braxtor. & None & &. & & & & \\
\hline$w v-1,3$ & wv & 013. & Calhoun & None & - & & & & & \\
\hline -NV-1,3 & wv & 015 & clay & None & $?$ & & & & & \\
\hline $\mathbf{n}-1,3$ & wo & 021 & Gilmer & None & & & & & & \\
\hline wv-1,3 & wv & 039 & Kanawha & $\begin{array}{l}\text { Amos, John E. Unit } 1,2 \\
\text { Amos, Jonh E. Unit . } 3 \\
\text { P.0. Box } 4000 \\
\text { St. Albans, WV } 25177 \\
1-304-.55-5301\end{array}$ & $\begin{array}{l}\text { AEP: Appalachlan Power Co. } \\
\text { 301 V1=ginia St. E. } \\
\text { Charleston, wV } 25302 \\
1-304-348-4700\end{array}$ & $\begin{array}{l}3 \text { m1 North of St. } \\
\text { Albans on W1nf1eld } \\
\text { Road (Route } 35 \text { ). }\end{array}$ & $\begin{array}{l}816.3 \text { ea } \\
1300.0\end{array}$ & $\begin{array}{l}\text { ST } \\
\text { ST }\end{array}$ & $\begin{array}{l}\text { Coal } \\
\text { Coal } \\
\cdots\end{array}$ & $\begin{array}{l}\text { Non } \\
\text { Non }\end{array}$ \\
\hline$w-1 ; 3$ & wV & 039 & Kanawha & $\begin{array}{l}\text { Cabin Creek Unit } 3,4 \\
\text { Cab1n Creek Unit } 8,9\end{array}$ & AEP: Appalachian Power Co. & & $\begin{array}{l}25.0 \\
85.0\end{array}$ & $\begin{array}{l}\text { ST } \\
\text { ST }\end{array}$ & $\begin{array}{l}\text { UNK } \\
\text { Coal }\end{array}$ & $\begin{array}{l}\text { UNK } \\
\text { Non }\end{array}$ \\
\hline$v=-1,3$ & wV & 039 & Kenawhe & Clayton Unit $1-4$ & AEP: Appalachian Power Co. & & 18.8 & HY & Water & Non \\
\hline$w /-1,3$ & wv & 039 & Kanawha & $\begin{array}{l}\text { Kanawha River Unit } 1,2 \\
\text { P.o. Box } 110 \\
\text { Glasgow, wV } 25086 \\
1-304-595-3480\end{array}$ & $\begin{array}{l}\text { AEP:- Appalach1an Power Co. } \\
1-304-348-4700\end{array}$ & $\begin{array}{l}20 \text { mi East of } \\
\text { Charleston }\end{array}$ & 213 & ST & Coal & Non \\
\hline
\end{tabular}


POWER PLANTS

\begin{tabular}{|c|c|c|c|c|c|c|c|c|c|c|}
\hline Coal Site & State & County Code & County & Plant/Address & Company/Address & Plant Location & $\begin{array}{l}\text { S1ze } \\
\text { MW }\end{array}$ & $\begin{array}{l}\text { Type } \\
\text { Un1t }\end{array}$ & Fue1 & $\begin{array}{l}\text { Alt. } \\
\text { Fue } 1 \\
\end{array}$ \\
\hline I-1 & I11. & 107 & Logan & None & & & & & & \\
\hline$I-1$ & I11. & 125 & Mason & $\begin{array}{l}\text { Havana Units } 1-5 \\
\text { Havana Un1t } 6 \\
\text { Route } 78, \text { Box } 368 \\
\text { Z1p } 62644 \\
1-309-543-2227\end{array}$ & $\begin{array}{l}\text { I11. Power Company } \\
500 \text { S. } 27 \text { th St. } \\
\text { Decatur, I11. } 62525 \\
\text { 1-217-424-6600 }\end{array}$ & $\begin{array}{l}35 \mathrm{mi} \text { West of Site } \\
0-1 \text { on I11. River }\end{array}$ & $\begin{array}{l}46 \text { ea. } \\
450\end{array}$ & $\begin{array}{l}\text { ST } \\
\text { ST }\end{array}$ & $\begin{array}{l}011 \\
\text { Coal }\end{array}$ & Noin \\
\hline $\mathrm{I}-1$ & 111. & 129 & Menard & None & & & & : & & \\
\hline $\mathrm{I}-2$ & I11. & 021 & Christian & $\begin{array}{l}\text { KIncald Unit } 1 \& 2 \\
\text { P.0. H } \\
\text { KIncaid, I11. } 62540 \\
1-217-237-4311\end{array}$ & $\begin{array}{l}\text { Commonwealth } \\
\text { Ed1son Company } \\
\text { P.0. Box } 767 \\
\text { Chicago, I11. } 60690 \\
1-312-294-4321\end{array}$ & $\begin{array}{l}4 \mathrm{ml} \text { West of } \\
\text { Kincald }\end{array}$ & 459.7 ea. & $\begin{array}{r}\mathbf{S T} \\
\vdots\end{array}$ & Coal & Non \\
\hline I-2 & I11. & 107 & Logan & None & & & & & & \\
\hline $\mathrm{I}-2$ & I11. & 115 & Macon & None & & & & & & \\
\hline $\mathrm{I}-2$ & I11. & 167 & Sanganon & $\begin{array}{l}\text { Dallman Unit } 1-2 \\
\text { Dallman Unit } 3 \\
3100 \text { Stevenson Dr. } \\
\text { Springf1eld, I11. } 62757 \\
1 .-217-789-2141\end{array}$ & City of Springfield & Springfield & $\begin{array}{l}90 \text { ea. } \\
192\end{array}$ & $\begin{array}{l}\text { ST } \\
\text { ST }\end{array}$ & $\begin{array}{l}\text { Coal } \\
\text { Coal }\end{array}$ & $\begin{array}{l}\text { Nou } \\
\text { Non } \\
\text {. }\end{array}$ \\
\hline $1-2$ & Int. & 167 & Sangamou & $\begin{array}{l}\text { Factory Unit } 1 \\
\text { Factory Unit } 2 \\
3100 \text { Stevenson Dr. } \\
\text { Springfield, I11. } 62757 \\
1-217-789-2141\end{array}$ & $\begin{array}{l}\text { C1ty of Springfield } \\
1-217-789-2147\end{array}$ & Springfield & $\begin{array}{l}27 \\
50\end{array}$ & $\begin{array}{l}\text { GT } \\
\text { GT }\end{array}$ & $\begin{array}{l}011 \\
011\end{array}$ & $\begin{array}{l}\text { Non } \\
\text { Non }\end{array}$ \\
\hline $\mathrm{I}-2$ & Il.1. & 167 & Sangamon & 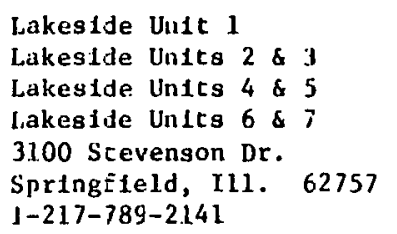 & $1-217-789-2147$ & Spriugfield & $\begin{array}{l}10 \\
15 \text { ea. } \\
20 \text { ea. } \\
38 \text { ea. }\end{array}$ & $\begin{array}{l}\text { ST } \\
\text { ST } \\
\text { ST } \\
\text { ST }\end{array}$ & $\begin{array}{l}\text { Coal } \\
\text { Coal } \\
\text { Coal } \\
\text { Coal }\end{array}$ & $\begin{array}{l}\text { Non } \\
\text { Non } \\
\text { Non } \\
\text { Non }\end{array}$ \\
\hline
\end{tabular}


POINER PLANTS

\begin{tabular}{|c|c|c|c|c|c|c|c|c|c|c|}
\hline Coal site & State & County Code & County & Plant/Addres8 & Company/Address & Plaht Location & $\begin{array}{l}\text { S1ze } \\
\text { MH }\end{array}$ & $\begin{array}{l}\text { Type } \\
\text { Unit }\end{array}$ & Fuel & $\begin{array}{l}\text { Alt. } \\
\text { Fuel }\end{array}$ \\
\hline $\mathrm{I}-2$ & 111 & 167 & Sanganion & Reynol ds & Clicy of Springfield & Springf leld & 18 & GT & 011 & Non \\
\hline$I-2$ & I11. & 167 & Sangạmon & $\begin{array}{l}\text { Undeglgnated } \\
\text { (Start-up 1986) }\end{array}$ & City of Springfield & Springfield & 192 & ST & Coal & UNK \\
\hline$I-3,4,5,6$ & I11. & 055 & Franklin & None & & & & & & \\
\hline$[-3,4,5,6$ & III. & 065 & Hamllton & $\begin{array}{l}\text { McLeansboro Unit } 1 \\
\text { McLeansboro Untt } 1 \\
\text { McLeansboro Unit } 2-4\end{array}$ & $\begin{array}{l}\text { CAty of McLeansburo } \\
1-6.18-643-2224\end{array}$ & City of McLeansboro & $\begin{array}{l}1 \\
1 \\
1 \& 2\end{array}$ & $\begin{array}{l}\text { IC } \\
\text { GT } \\
\text { IC }\end{array}$ & $\begin{array}{l}\text { UNK } \\
\text { UNK } \\
\text { UNK }\end{array}$ & $\begin{array}{l}\text { UNK } \\
\text { UNK } \\
\text { UNK }\end{array}$ \\
\hline$I-3,4,5,6$ & I11. & 081 & Jef ferson & None & $\cdot$ & & & & $\cdot$ & \\
\hline $1-3,4,5,6$ & 111. & 191 & Wayne & 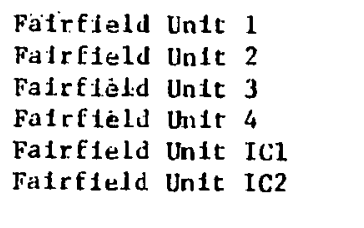 & $\begin{array}{l}\text { Fairfield Munictpal } \\
\text { Light Plant } \\
1-618-842-4821 \\
1-618-842-3445\end{array}$ & City of Falrfield & $\begin{array}{l}1.5 \\
2.5 \\
.4 .0 \\
5.0 \\
2.0 \\
2.0\end{array}$ & $\begin{array}{l}\text { ST } \\
\text { ST. } \\
\text { ST } \\
\text { ST } \\
\text { IC } \\
\text { IC }\end{array}$ & $\begin{array}{l}\text { Coal } \\
\text { Coa1 } \\
\text { Coal } \\
\text { Coal } \\
\text { Gas } \\
\text { Gas }\end{array}$ & $\begin{array}{l}\text { Non } \\
\text { Non } \\
\text { Non } \\
\text { Non } \\
\text { FO2 } \\
\text { FO2 }\end{array}$ \\
\hline$K-1$ & Ky. & 031 & Butler & Nowe & . & $\cdot$ & & & & \\
\hline$k-1$ & Ky. & $17 \%$ & Mulenburg & $\begin{array}{l}\text { Green River Untt } 1 \& 2 \\
\text { Green River Unit } 3 \\
\text { freen H.1ver Unit } 4 \\
\text { Box } 191 \\
\text { Central City, Kentucky } \\
1-502-754-4541\end{array}$ & $\begin{array}{l}\text { Ken:ucky Utilitles co. } \\
\text { P.o. Box } 616 \\
\text { Cencral City, Kentucky } \\
1-502-754-4272\end{array}$ & $\begin{array}{l}9 \mathrm{ml} \text {. N. of Central } \\
\text { C1ty on Green River } \\
\text { or about } 4 \mathrm{ml} \text { N. of } \\
\text { S1te } \mathrm{K}-1 \\
\vdots\end{array}$ & $\begin{array}{l}30 \text { ea. } \\
60 \\
100\end{array}$ & $\begin{array}{l}\text { ST } \\
\text { ST } \\
\text { ST }\end{array}$ & $\begin{array}{l}\text { Coal } \\
\text { Coal } \\
\text { Coal }\end{array}$ & $\begin{array}{l}\text { Non } \\
\text { Non } \\
\text { Non }\end{array}$ \\
\hline
\end{tabular}


POWER PLANTS

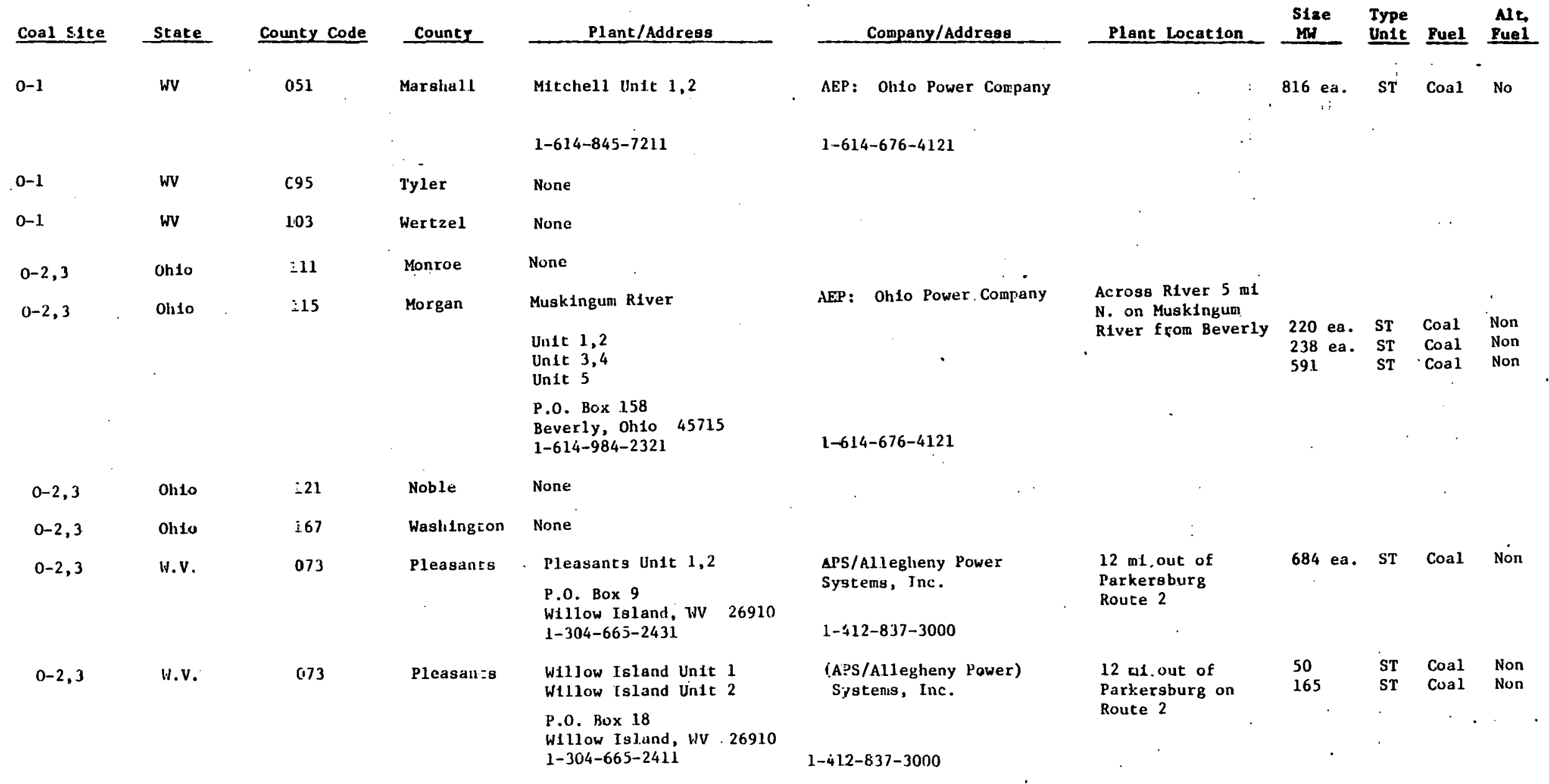




\section{POWER PLANTS}

\begin{tabular}{|c|c|c|c|c|c|c|c|c|}
\hline Coal stce & State & County Code & County & Plant/Address & Company/Addrees & Plane Locacton & $\begin{array}{l}\text { 81ze } \\
M U\end{array}$ & $\begin{array}{l}\text { Type } \\
\text { Un1t Puel }\end{array}$ \\
\hline $0-2,3$ & w.v. & 095 & Tyler & None & & & $\therefore i$ & . \\
\hline $0-2,3$ & w.v. & 107 & Wood & None & & $\cdot$ & & \\
\hline
\end{tabular}

ST - Steam Turblne

GT - Gas Turbine

HY - Hydroelectric

IC - Internal Combustion 
POHER PLANTS

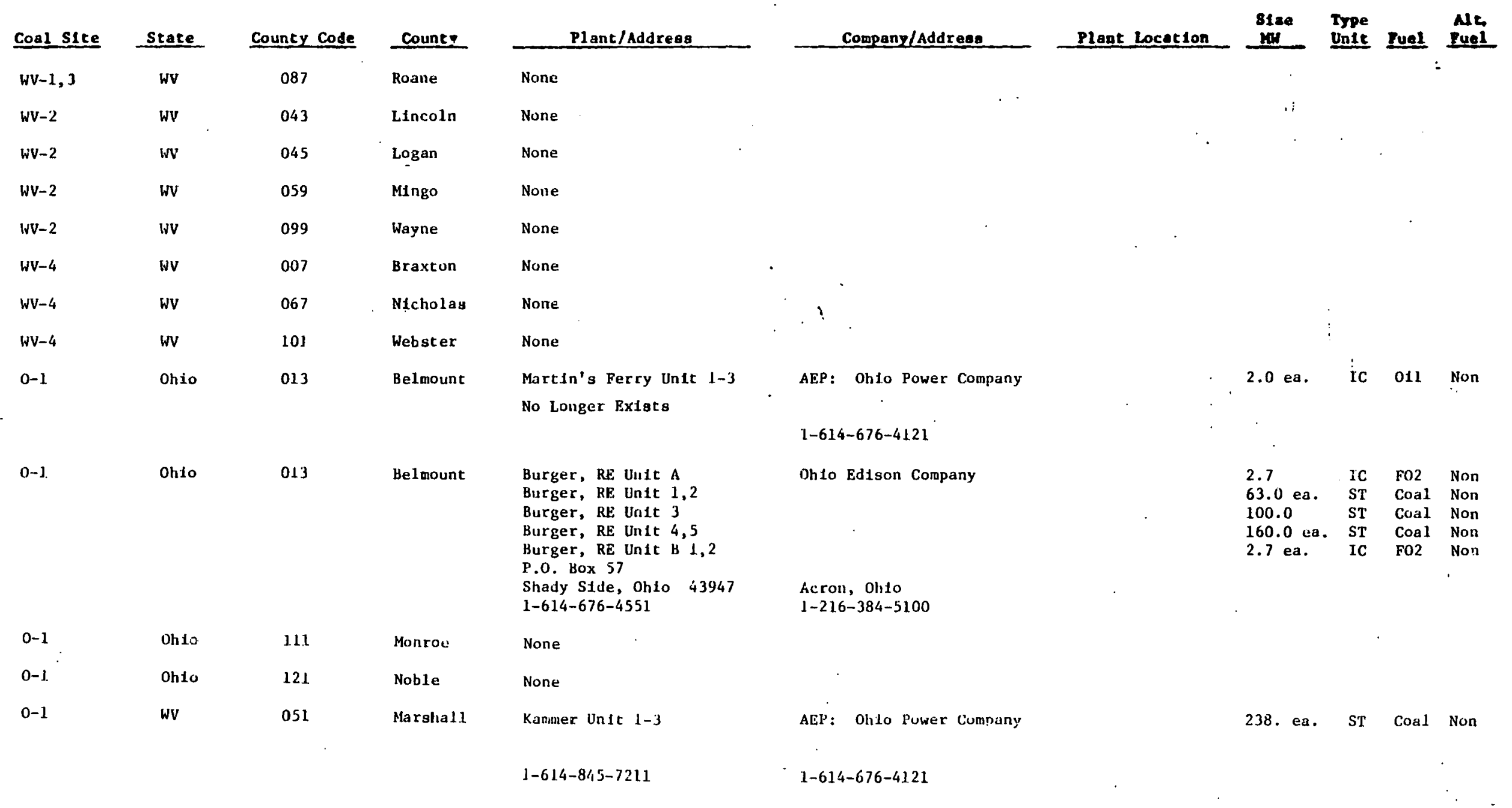

